\title{
Generalized Estimates from Streamflow Data of Annual and Seasonal Ground- Water-Recharge Rates for Drainage Basins in New Hampshire
}

By Robert H. Flynn and Gary D. Tasker

In cooperation with the

New Hampshire Department of Environmental Services

Scientific Investigations Report 2004-5019 


\title{
U.S. Department of the Interior Gale A. Norton, Secretary
}

\author{
U.S. Geological Survey \\ Charles G. Groat, Director
}

U.S. Geological Survey, Pembroke, New Hampshire: 2004

\author{
For sale by U.S. Geological Survey, Information Services \\ Box 25286, Denver Federal Center \\ Denver, CO 80225 \\ For more information about the USGS and its products: \\ Telephone: 1-888-ASK-USGS \\ World Wide Web: http://www.usgs.gov/
}

\begin{abstract}
Any use of trade, product, or firm names in this publication is for descriptive purposes only and does not imply endorsement by the U.S. Government.

Although this report is in the public domain, permission must be secured from the individual copyright owners to reproduce any copyrighted materials contained within this report.
\end{abstract}




\section{Contents}

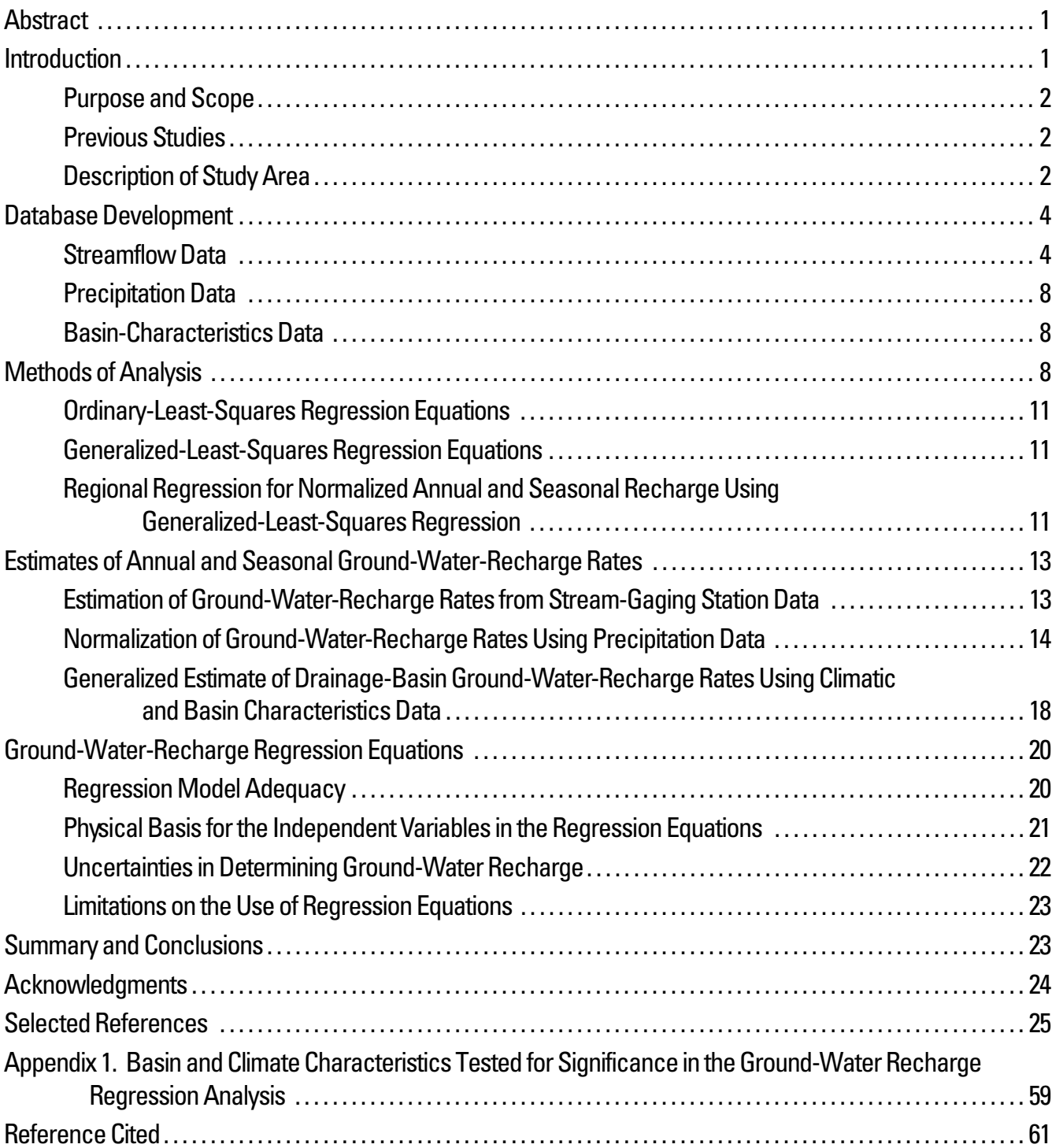

\section{Figures}

1-2. Maps showing-

1. Locations of streams, drainage basins, and stream-gaging stations in the study area that were used to develop the equations for estimating ground-water-recharge statistics for New Hampshire.

2. Locations of drainage basins, associated towns, and physiographic provinces in the study area.

3-7. Graphs showing distribution of rates of ground-water recharge in New Hampshire for:

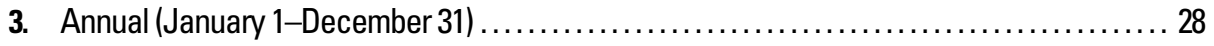

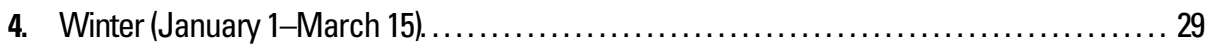




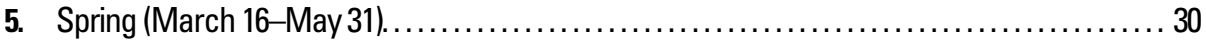

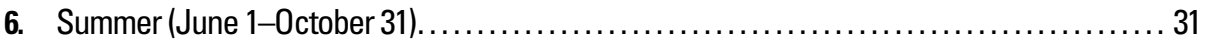

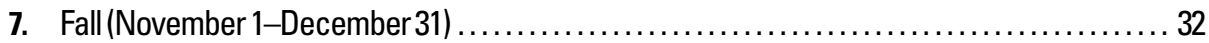

8-12. Maps showing drainage basins that were used to develop the equations for estimating groundwater-recharge statistics in New Hampshire showing the proportion (in percent) of normalized ground-water recharge to basin-centroid precipitation for:

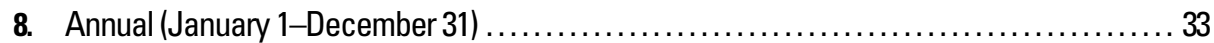

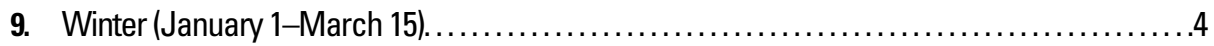

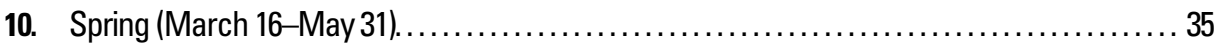

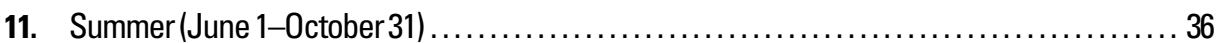

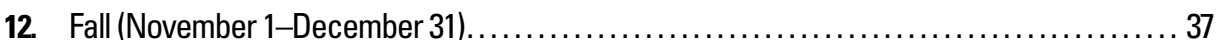

\section{Tables}

1. Descriptions of stream-gaging stations used to develop the regression equations for estimating ground-water recharge in New Hampshire drainage basins. ...

2. Basin characteristics for stream-gaging stations used in the ground-water recharge regression-analysis equations for New Hampshire drainage basins .......................

3-7. Normalized basin recharge rates determined from basin-specific regression equations relating Rorabaugh-method-determined ground-water-recharge rates and basin-centroid precipitation for:

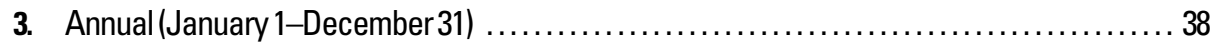

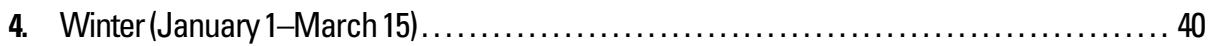

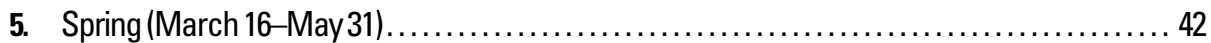

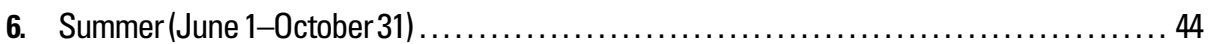

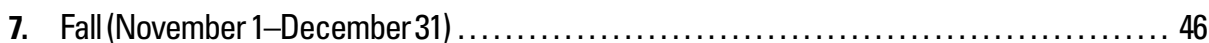

8. Values of seasonal and annual basin-centroid precipitation and normalized ground-water recharge and the proportion (in percent) of normalized seasonal and annual ground-water recharge to seasonal and annual basin-centroid precipitation .......................... 16

9-13. Ground-water recharge statistics, standard error of prediction, and 90-percent prediction interval estimated using available data and regression-equation predicted values for:

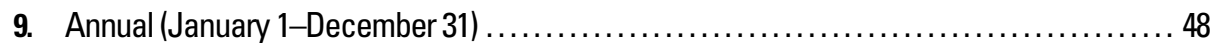

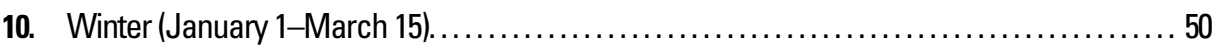

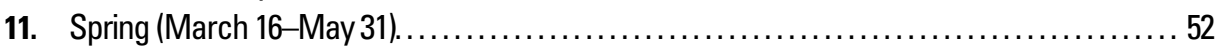

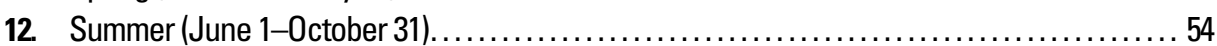

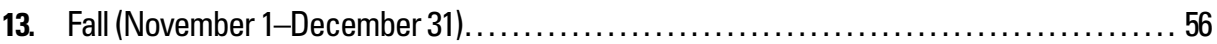

14. Summary of regression equations and measures of model adequacy for estimating ground-water-recharge statistics at selected New Hampshire stream-gaging stations ......... 20

15. Ranges of basin characteristics used to develop the regression equations for estimating ground-water-recharge rates in New Hampshire drainage basins. 


\section{Conversion Factors, Vertical Datum, Abbreviations, and Acronyms}

\begin{tabular}{lcl}
\hline Multiply & By & To obtain \\
\hline inch (in.) & Length & \\
foot (ft) & 25.4 & millimeter $(\mathrm{mm})$ \\
mile (mi) & 0.3048 & meter $(\mathrm{m})$ \\
\hline & 1.609 & kilometer $(\mathrm{km})$ \\
\hline square mile $\left(\mathrm{mi}^{2}\right)$ & Area & \\
\hline & 2.590 & square kilometer $\left(\mathrm{km}^{2}\right)$ \\
\hline foot per day $(\mathrm{ft} / \mathrm{d})$ & Flow rate & \\
cubic foot per second $(\mathrm{ft} / \mathrm{s})$ & 0.3048 & meter per day $(\mathrm{m} / \mathrm{d})$ \\
gallon per day $(\mathrm{gal} / \mathrm{d})$ & 0.02832 & cubic meter per second $\left(\mathrm{m}^{3} / \mathrm{s}\right)$ \\
inch per year $(\mathrm{in} / \mathrm{yr})$ & 0.003785 & cubic meter per day $\left(\mathrm{m}^{3} / \mathrm{d}\right)$ \\
\hline
\end{tabular}

Temperature in degrees Fahrenheit $\left({ }^{\circ} \mathrm{F}\right)$ may be converted to degrees Celsius $\left({ }^{\circ} \mathrm{C}\right)$ as follows:

$$
{ }^{\circ} \mathrm{C}=\left({ }^{\circ} \mathrm{F}-32\right) / 1.8
$$

Vertical coordinate information is referenced to the National Geodetic Vertical Datum of 1929 (NGVD 1929).

\section{ABBREVIATIONS AND ACRONYMS USED IN THIS REPORT}

Organizations

CSRC Complex Systems Research Center at the University of New Hampshire

ESRI Environmental Systems Research Institute

NCDC National Climate Data Center

NHDES New Hampshire Department of Environmental Services

NRCS Natural Resources Conservation Service

UNH University of New Hampshire

USGS U.S. Geological Survey

\section{Basin Characteristics}

ABT Average mean annual basin temperature, in degrees Fahrenheit

ACP Average annual basin-centroid precipitation, in inches

AGP Average annual gage precipitation, in inches

ASC Average annual basin snowcover, in inches

C Coniferous forest in the drainage basin, in percent

CD Mixed coniferous/deciduous forest in the drainage basin, in percent

FCP Average fall basin-centroid precipitation, in inches 
SGP Average summer gage precipitation, in inches

SpGP Average spring gage precipitation, in inches

WBT Average mean winter basin temperature, in degrees Fahrenheit

\section{Miscellaneous}

APE Average Prediction Error of Model

AP-RASA Appalachian and Piedmont physiographic provinces Regional Aquifer System Analysis

ARC-INFO ESRI GIS spatial analysis software

DEM Digital elevation model of topography

EGLS Estimated generalized-least-squares

GIS Geographic information system

GLS Generalized-least-squares regression analysis

GLSNET Generalized-least-squares network computer software

HUC Hydrologic unit code

IDW Inverse Distance Weighting

MSE Mean square error

NLCD National Land Cover Dataset

OLS Ordinary-least-squares regression analysis

PRESS Predicted REsidual Sum of Squares statistic

PRISM Parameter-elevation regressions on independent slopes model

$R^{2}$ adj $\quad$ Adjusted $R$ squared

RSQUARE All-possible-regression algorithm in SAS

RORA Recession-curve-displacement computer program

RECESS Streamflow recession index computer program

SAS Statistical analysis system computer software

STATSGO State soil geographic data base

VIF Variance inflation factor

WLS Weighted-least-squares regression analysis 


\title{
Generalized Estimates from Streamflow Data of Annual and Seasonal Ground-Water-Recharge Rates for Drainage Basins in New Hampshire
}

\author{
By Robert H. Flynn and Gary D. Tasker
}

\section{Abstract}

This report presents regression equations to estimate generalized annual and seasonal ground-water-recharge rates in drainage basins in New Hampshire. The ultimate source of water for a ground-water withdrawal is aquifer recharge from a combination of precipitation on the aquifer, ground-water flow from upland basin areas, and infiltration from streambeds to the aquifer. An assessment of ground-water availability in a basin requires that recharge rates be estimated under 'normal' conditions and under assumed drought conditions.

Recharge equations were developed by analyzing streamflow, basin characteristics, and precipitation at 55 unregulated continuous record stream-gaging stations in New Hampshire and in adjacent states. In the initial step, streamflow records were analyzed to estimate a series of annual and seasonal ground-water-recharge components of streamflow in each drainage basin evaluated in this study. Regression equations were then developed relating the series of annual and seasonal ground-water-recharge values to the corresponding series of annual and seasonal precipitation values as determined at the centroid of each drainage basin. This resulted in one equation for each of the 55 basins for each of the four seasonal periods and the annual period, or a total of 275 regression equations. Average annual and seasonal precipitation data for 1961-90 were then used to compute a set of normalized ground-waterrecharge values that reflected the long-term average annual and seasonal variations (normalized) and mean recharge characteristics of each drainage basin. Ordinary-least-squares regression was applied in the process of selecting 10 out of 93 possible basin and climatic characteristics for further testing in the development of the equations for computing the generalized estimate of annual and seasonal ground-water recharge based on the set of normalized recharge values. Generalized-leastsquares regression was used for the final parameter estimation and error evaluation. The following basin and climatic characteristics were found to be statistically significant predictors for at least one of the dependent variables: average annual, summer, and spring precipitation as determined at U.S. Geological Survey stream-gaging stations; average annual basin-centroid precipitation; average mean annual basin temperature; average minimum winter basin temperature; percent coniferous forest in a basin; percent mixed coniferous and deciduous forest in a basin; average fall basin-centroid precipitation; and average annual snowcover. These 10 basin and climatic characteristics were selected because they were statistically significant based on several statistical parameters that evaluated which combination of characteristics contributed the most to the predictive accuracy of the regression-equation models. A geographic information system is required to measure the values of the predictor variables for the equations developed in the study.

The average annual normalized ground-water recharge was $21.0 \mathrm{in}$. This value was determined by generalized-leastsquares (GLS) regression analysis for all of the basins used in the normalized ground-water recharge analysis for precipitation from 1961-90. The average winter (January 1-March 15) ground-water recharge was 4.3 in., average spring (March 16May 31) ground-water recharge was 9.0 in., average summer (June 1-October 31) ground-water recharge was $4.0 \mathrm{in}$., and average fall (November 1-December 31) ground-water recharge was 3.6 in. Normalized ground-water recharge ranged annually from 12.3 to $31.8 \mathrm{in}$., for winter from 2.30 to $7.82 \mathrm{in}$., for spring from 5.16 to $13.7 \mathrm{in}$., for summer from 1.45 to $10.2 \mathrm{in}$., and for fall from 2.21 to $6.06 \mathrm{in.}$

\section{Introduction}

The population of New Hampshire is growing faster than in any other State in the northeastern United States. The population grew by approximately 141,000 people or 11.4 percent from 1990 to 2000 (New Hampshire State Data Center, 2001). Another 215,000 people are expected to live in the State by the year 2025 (New Hampshire State Data Center, 2001). An increase in population and industry, especially along the seacoast and south-central New Hampshire, has resulted in an increased demand for water.

The development of large ground-water supplies associated with rapid population growth in New Hampshire has raised concern regarding the sustainability of the water supply and the balancing of competing demands between various water users. New, large withdrawals may have adverse effects on existing 


\section{Streamflow Data of Annual and Seasonal Ground-Water Recharge Rates for Drainage Basins in New Hampshire}

wells, streamflows, and wetlands. Recent development of large ground-water supplies in the seacoast region of New Hampshire may be in competition with existing uses and has raised concern for environmentally sensitive areas.

In 1998, the New Hampshire Ground Water Protection Act and the New Hampshire Safe Drinking Water Act were amended to require that potential effects from large groundwater withdrawals be identified and addressed during the permitting process. The legislation requires the New Hampshire Department of Environmental Services (NHDES) to develop procedures to insure that any new, large ground-water withdrawal (a withdrawal that exceeds 57,600 gal/d over any 24-hour period) does not adversely affect existing ground-water users or water resources. To accomplish this, hydrologic tools are needed that can be used to assess regional hydrologic conditions. Such tools would be useful to water-resources managers in administering New Hampshire regulatory programs associated with source-water and drainage-basin protection.

Determination of ground-water-recharge values will aid Federal, State and local officials, and private interests in making water-resource, regulatory, and management decisions. The U.S. Geological Survey (USGS), in cooperation with the NHDES, has developed datasets, hydrologic statistical relations, and a geographic information system (GIS) of data coverages for all of New Hampshire to better understand water availability. This information provides a basis for sustainable water management for the benefit of water users and the environment.

Ground-water recharge is commonly defined as the volume of water reaching the saturated zone by downward infiltration of water, primarily from precipitation. For the purposes of this study, ground-water recharge is the long-term average observable recharge, which is defined as that part of recharge that becomes observable as streamflow in a drainage basin. Recharge flowing out of a drainage basin as ground water, or that which is lost to evapotranspiration, is considered unobservable. Sources of ground-water recharge include rainfall, seepage from streams and lakes, percolation of applied irrigation water, effluent from septic-tank drainage fields, leakage from water and sewer conduits, and wastewater discharged to the ground surface. The amount of precipitation, which becomes ground-water recharge under natural conditions, is affected by many factors including (1) texture and gradation of surface and near-surface deposits and their vertical permeability; (2) nature and water requirements of the vegetation; (3) frequency, intensity, and volume of rainfall; (4) topography; and (5) temperature (American Society of Civil Engineers, 1987). The amount of ground-water recharge can be increased and ground-water flow to surface-water bodies can be reduced as a result of withdrawal of ground water. In addition, the direction of ground-water flow to a surface-water body can be reversed by nearby pumped wells that can cause water to flow from surface-water bodies to aquifers.

\section{Purpose and Scope}

The purpose of this report is to present a method for the generalized estimates of annual and seasonal ground-waterrecharge rates in New Hampshire drainage basins. This report describes (1) an indirect method, called the recession-curvedisplacement method, for determining a series of annual and seasonal ground-water-recharge rates at 55 unregulated streamgaging stations in New Hampshire and in adjacent states; (2) the relation of the series of annual and seasonal ground-waterrecharge values to the corresponding series of annual and seasonal basin-centroid precipitation values for each drainage basin through regression analyses; (3) the development of a set of normalized annual and seasonal ground-water-recharge values corresponding to average annual and seasonal basin precipitation from 1961 to 1990; (4) the development of regression equations to relate normalized ground-water recharge to basin and climatic characteristics that can be used to determine ground-water recharge in any basin in New Hampshire; and (5) the spatial variation and uncertainty in the regressionderived ground-water-recharge rates. Ground-water-recharge rates developed in this report approximate the average recharge rates for the period from 1961 to 1990.

\section{Previous Studies}

Previous studies used streamflow data to make estimates of ground-water recharge rates. These include studies in Michigan (Holtschlag, 1997), Maine (Morrissey and others, 1988), Nevada (Savard, 1998), Massachusetts (Bent, 1995 and 1998), Tennessee (Hoos, 1990), and Valley and Ridge, Blue Ridge, and Piedmont Physiographic Provinces of the eastern and southeastern United States (Rutledge and Mesko, 1996).

\section{Description of Study Area}

New Hampshire encompasses an area of $8,973 \mathrm{mi}^{2}$ of which $309 \mathrm{mi}^{2}$ is water (New Hampshire State Data Center, 2001) (fig. 1). The State is in the Seaboard Lowland, New England Upland, and White Mountain sections of the New England Physiographic Province (Fenneman, 1938). The southeastern part of the State primarily is coastal plain, the central region primarily is lowland and foothills, and the northern part primarily is mountainous. The elevation and amount of topographic relief gradually increase from south to north. Precipitation ranges from an annual mean of about 35 in. in the Connecticut and Merrimack River valleys to about 90 in. on the summit of Mt. Washington (Hammond, 1989). Typically, statewide, the driest month is February. The wettest months are November and December in the area south of the White Mountains, and June, July, and August in the area north of the White Mountains (Hammond, 1989). Average runoff ranges from $18 \mathrm{in} / \mathrm{yr}$ in parts of the Connecticut River Valley and seacoast area to about $42 \mathrm{in} / \mathrm{yr}$ in the White Mountains. Streamflow varies both seasonally and geographically. High flows typically occur during 


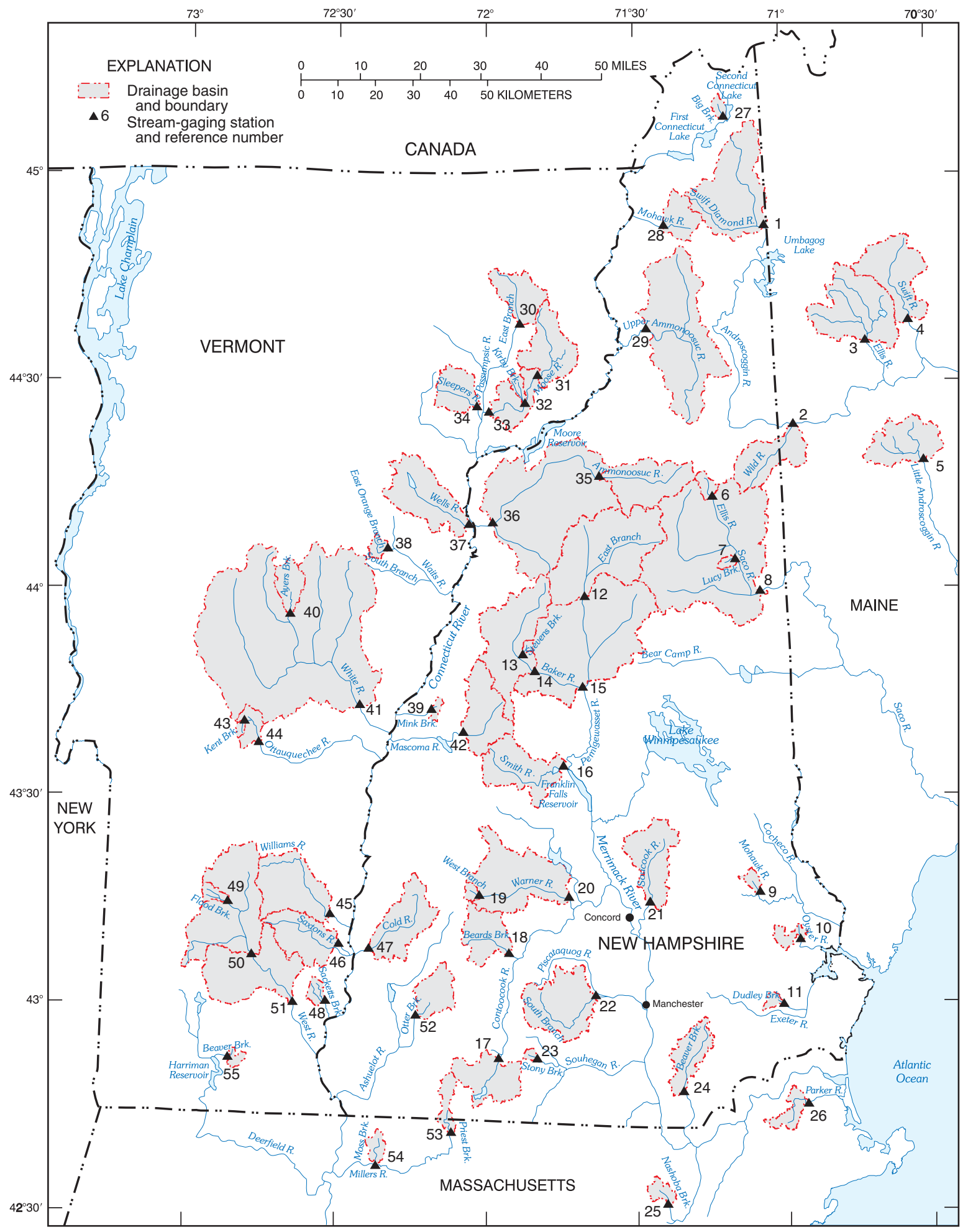

Base from U.S. Geological Survey

Digital data, $1983,1: 24,000$ or $1: 25,000$

Figure 1. Locations of streams, drainage basins, and stream-gaging stations in the study area that were used to develop the equations for estimating ground-water-recharge statistics for New Hampshire. (For detailed information on the stations, refer to table 1.) 
March, April, and May and are caused by the melting snowpack and concurrent precipitation (U.S. Geological Survey, 1990). Snowfall ranges from about $50 \mathrm{in} / \mathrm{yr}$ along the coast to approximately $100 \mathrm{in} / \mathrm{yr}$ in the White Mountains (Hammond, 1989).

New Hampshire is in the glaciated Appalachian groundwater region (Billings, 1956). The bedrock consists of metasedimentary rock in approximately two-thirds of the State and intrusive rock in the other third (Billings, 1956). The two principal types of aquifers in New Hampshire are stratified-glacial drift and crystalline bedrock. Till is the most extensive glacial deposit in New Hampshire and is either buried beneath stratified-drift deposits in valleys or lowlands, or overlies bedrock in upland areas (Flanagan and others, 1999). Other stratified-drift deposits include marine clays and fine- and coarse-grained sands along the seacoast, outwash sands and gravels, and fineand coarse-grained glacial-lake deposits (Medalie and Moore, 1995). Stratified-drift deposits are primarily in the valleys of major streams. The lowlands and foothills region of New Hampshire has thicker deposits of till on the slopes and more prevalent and larger areal distributions of stratified drift along streams than elsewhere in the state.

Soils in New Hampshire are predominantly grouped into two soil hydrologic classifications (U.S. Department of Agriculture's State Soil Geographic (STATSGO) soils database, 1991; U.S. Geological Survey, 1997; and Schwarz and Alexander, 1995). These classifications include (1) soils with moderate infiltration rates (deep and moderately deep soils, moderately well and well-drained soils with moderately coarse textures), and (2) soils with slow infiltration rates (soils with layers impeding downward flow of water or soils with moderately fine textures). Soils with moderate infiltration rates occur in areas of high slope, such as the White Mountains, and in areas of stratified-drift deposits. Soils with slow infiltration rates occur in areas where glacial till is commonly found at the surface. STATSGO soils classifications reflect properties of soils that affect the residence time and amount of precipitation percolating into the soil surface (Flanagan and others, 1999).

Three general land-use categories are defined by the New Hampshire Division of Forests and Lands (1997). These categories are forest land, farm land, and other nonforest land. New Hampshire is the second most forested state in the United States, according to the New Hampshire Division of Forests and Lands (1997). Forest land is classified as either timberland or noncommercial. Timberland is capable of producing timber crops and is potentially available for harvesting. Noncommercial forest land includes productive but reserved forest lands, unproductive forests, and urban forests. In 1997, forest land constituted 84 percent of land in New Hampshire, farm land constituted 3 percent, and other nonforest land (including urbanized and industrial areas) constituted 13 percent (New Hampshire Division of Forests and Lands, 1997).

\section{Database Development}

Streamflow, precipitation, and basin-characteristics data were compiled for this study from several sources. Streamflow data were obtained from USGS stream-gaging stations to estimate ground-water recharge. Precipitation data were obtained from the National Climate Data Center (NCDC) digitalprecipitation database as compiled by EarthInfo, Inc. (2000) to develop a relation with the ground-water recharge. The 2-kilometer grid Parameter-elevation Regression on Independent Slopes Model (PRISM) precipitation data for 1961-90 was used to normalize ground-water recharge. The NCDC database contains precipitation-gage data beginning with the year 1949. Basin-characteristics data were measured within a GIS with the spatial analysis software ARC-INFO (Environmental Systems Research Institute, Inc., 1994) using available and created data layers to develop a generalized estimate of ground-water recharge.

\section{Streamflow Data}

The USGS operates a network of stream-gaging stations that provide continuous information on streamflow throughout the United States. From active and discontinued stations in New Hampshire and adjacent states, 60 unregulated stations were initially chosen for this study and between 48 and 55 stations were used in determining final annual and seasonal groundwater-regression equations. The 55 stream-gaging stations that were selected met the following criteria: (1) a minimum of 10 years of continuous record data from 1948 through 1998 (shorter records may not provide a sufficient sample of the temporal variations in streamflow), (2) no effects of regulation, diversion, or augmentation on streamflow, and (3) surface- and ground-water divides that are thought to be approximately coincident. For continuous-record stream-gaging stations on streams with regulated and unregulated records, only the unregulated records were selected for determining annual and seasonal ground-water-recharge characteristics. Daily mean flows at the unregulated stations were used to determine ground-water recharge.

The names and descriptions of the stream-gaging stations are in table 1. Locations of the stations, streams, and associated drainage basins are shown on figure 1 . The locations of the New Hampshire towns, associated drainage basins, and physiographic provinces are shown on figure 2 .

The seasonal periods for the ground-water-recharge statistics were defined by the NHDES to manage surface-water supplies for the following seasons: winter (January 1-March 15), spring (March 16-May 31), summer (June 1-October 31), and fall (November 1-December 31). 
Table 1. Descriptions of stream-gaging stations used to develop the regression equations for estimating ground-water recharge in New Hampshire drainage basins.

[No., number; fig., figure; $\mathrm{mi}^{2}$, square miles]

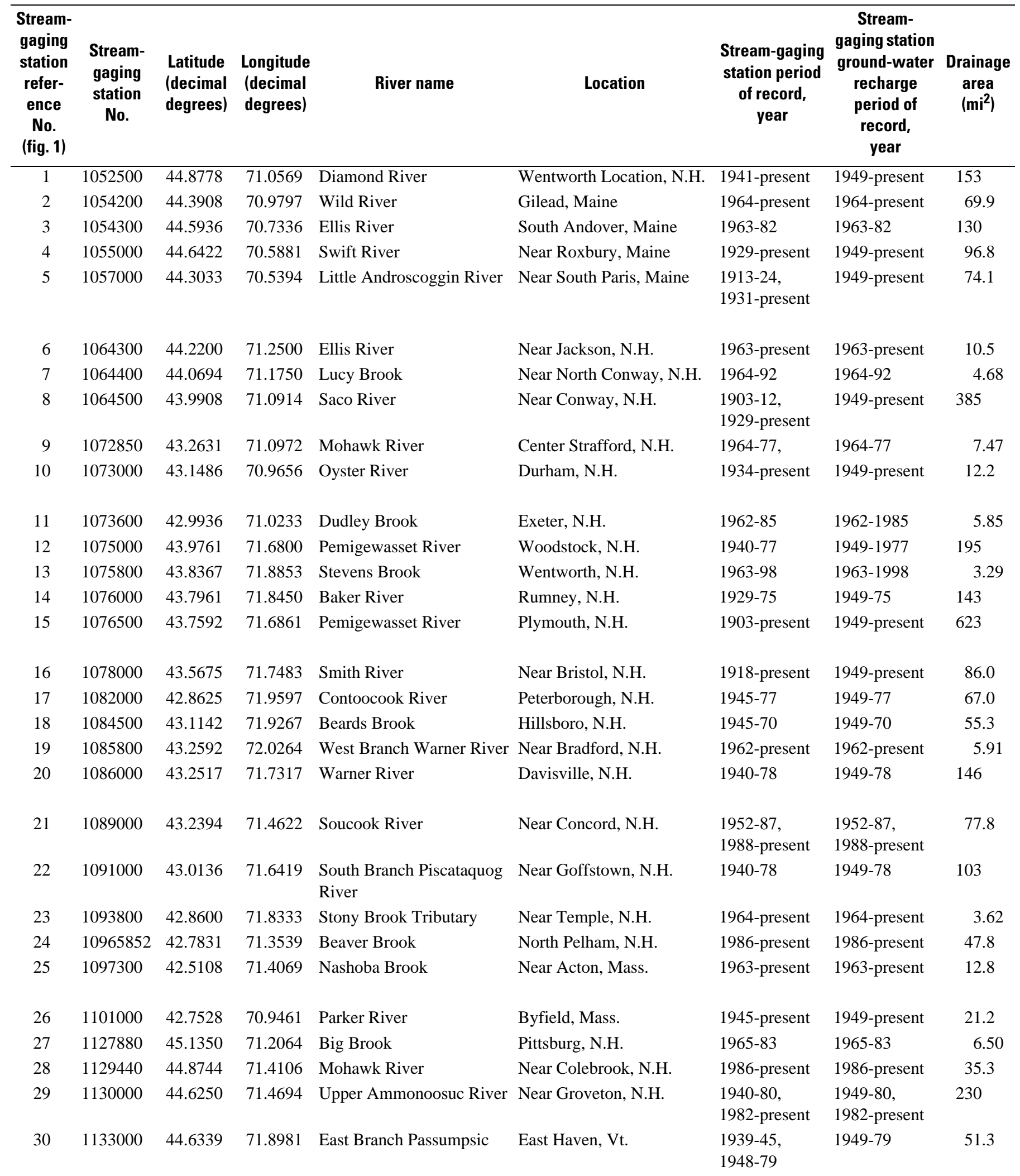




\section{Streamflow Data of Annual and Seasonal Ground-Water Recharge Rates for Drainage Basins in New Hampshire}

Table 1. Descriptions of stream-gaging stations used to develop the regression equations for estimating ground-water recharge in New Hampshire drainage basins.-Continued

[No., number; fig., figure; $\mathrm{mi}^{2}$, square miles]

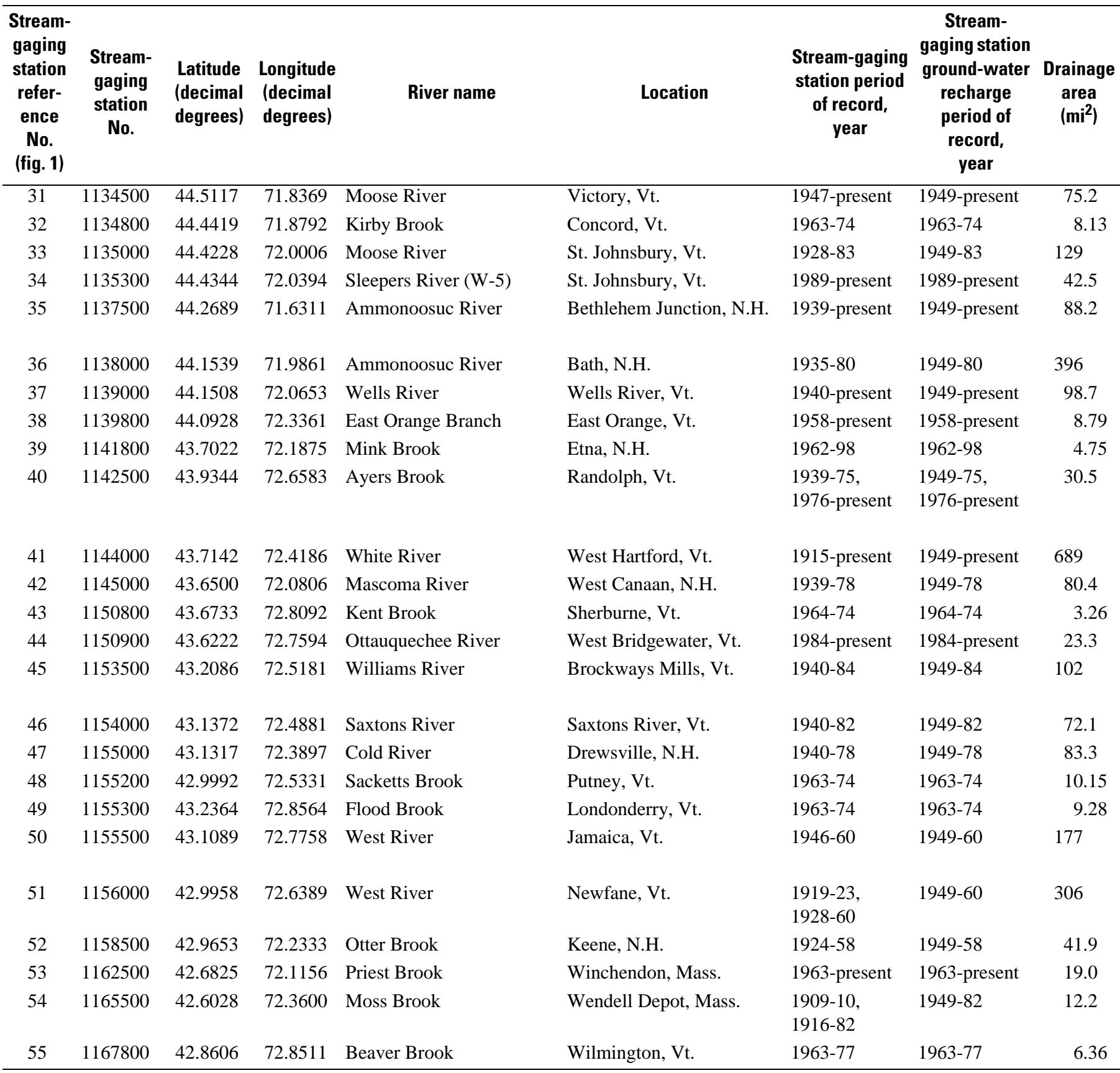




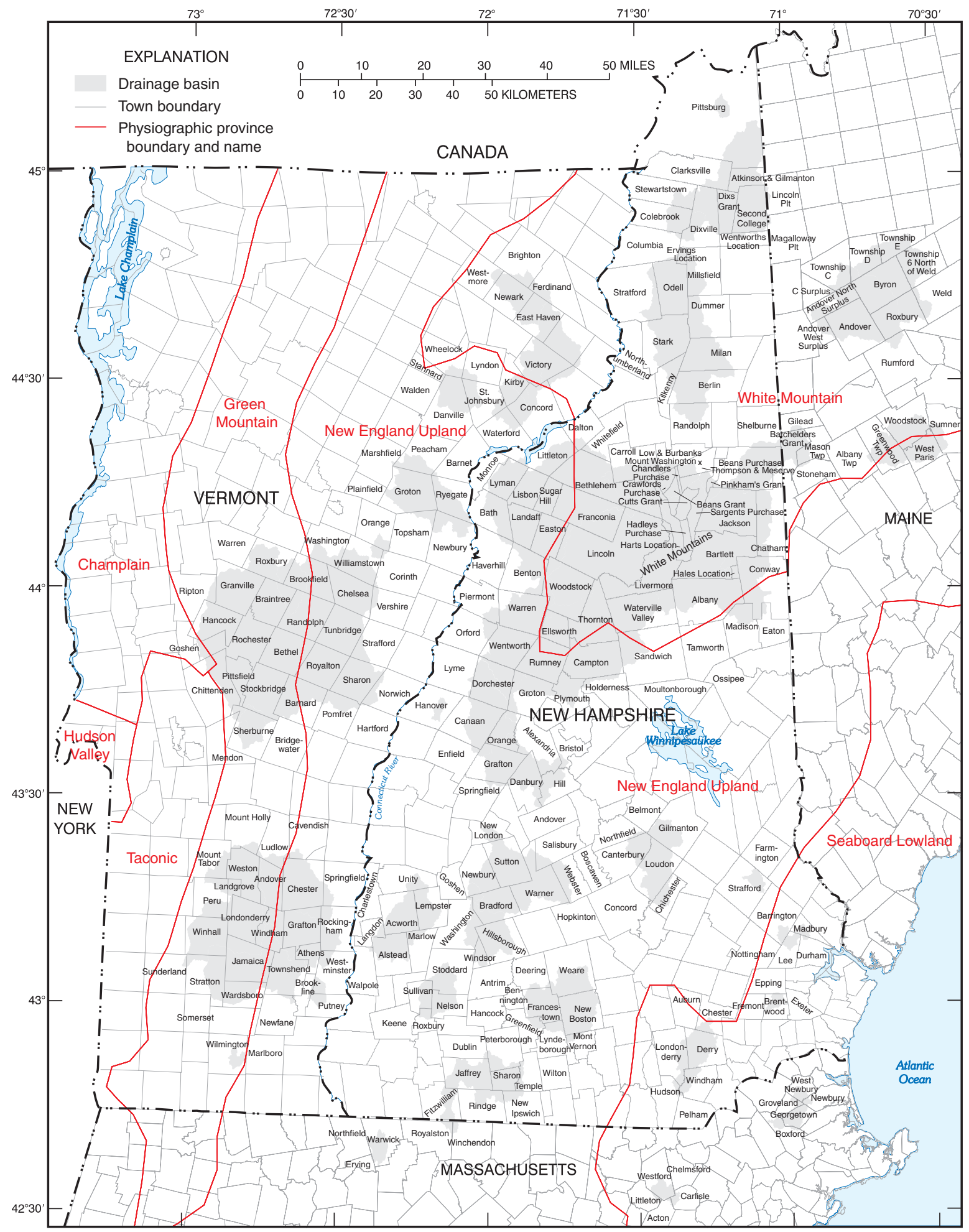

Base from U.S. Geological Survey

Digital data, $1983,1: 24,000$ or $1: 25,000$

Figure 2. Locations of drainage basins, associated towns, and physiographic provinces in the study area. (For detailed information on the stations, refer to table 1.) 


\section{Streamflow Data of Annual and Seasonal Ground-Water Recharge Rates for Drainage Basins in New Hampshire}

\section{Precipitation Data}

The range of the digital NCDC precipitation data for development of the 275 (55 unregulated stations with 4 seasons and 1 annual period) annual and seasonal basin-specific regression equations was from 1949 to 1998 . Between 48 and 55 stations were used in the development of the final regression equations because 10 years of seasonal or annual streamflow and ground-water-recharge data were not available at some stations after 1949.

Drainage-basin-centroid precipitation was estimated from a weighted average of nearby NCDC precipitation-gage data. When seasonal or annual data for a nearby precipitation gage were not complete, the next nearest precipitation gage was used in conjunction with other nearby precipitation gages to determine the drainage-basin-centroid precipitation for that particular year or season.

For consistency among stations that have operated during different periods of time, the annual and seasonal ground-waterrecharge values were normalized by substituting the average annual and seasonal (respectively) basin-centroid values of precipitation, as determined from the PRISM (Daly, 2000) data from 1961 to 1990, into each of the annual and seasonal basinrecharge equations for the NCDC basin-centroid-determined precipitation dependent variables. PRISM data were derived from data collected at National Oceanic and Atmospheric Administration (NOAA), SNOwpack TELemetry (SNOTEL), and State collection sites. NCDC data were derived from National Weather Service (NWS) precipitation-gage data.

\section{Basin-Characteristics Data}

The values of 93 physical and climatic (annual and seasonal) candidate explanatory variables (independent variables) were determined for each drainage basin upstream of the 55 unregulated stream-gaging stations (Appendix 1). The values of the measured drainage-basin characteristics used in the regression analyses for each of the stream-gaging stations are provided in table 2. All of the basin characteristics were measured within a GIS (Environmental Systems Research Institute, Inc., 1994) using available and created data layers. The digital data layers include, but are not limited to, (1) subwatersheds at 1:24000 scale delineated by the Natural Resources Conservation Service (NRCS) and identified by 12-digit Hydrologic Unit Codes (HUCS), (2) centerline hydrography for New Hampshire at 1:24000 and 1:25000 scale developed by Complex Systems Research Center (CSRC) at the University of New Hampshire (UNH) (Complex Systems Research Center, unpublished digitized data, 2000), and (3) USGS Digital Elevation Models (DEMs) at 1:24000 scale.

Some of the basin characteristics tested for inclusion in the regression equations (Appendix 1) were obtained with the drainage-basin-characteristics determination program BasinSoft (Harvey and Eash, 1995). The basin characteristics determined with BasinSoft were basin length, basin perimeter, basin relief, basin azimuth, effective basin width, shape factor, compactness ratio, relative relief, main channel length, main channel slope, main channel sinuosity ratio, main channel slope proportion, stream density, ruggedness number, and slope ratio.

Precipitation, temperature, and snowcover data were acquired from PRISM datasets (Daly, 2000). PRISM is an analytical tool that uses point data, DEMs, and other spatial datasets to generate gridded estimates of annual, monthly, and event-based climatic parameters such as precipitation (Daly, 2000). The PRISM data contain polygon coverages of average monthly and annual climatological data for 1961-90. PRISMderived raster data are the underlying datasets from which the polygons and vectors for the data layers were created. The PRISM data incorporate topographic effects on precipitation and include coastal and lake effects on precipitation.

The percent of the drainage basin that is coniferous or mixed coniferous and deciduous forest was acquired from the National Land Cover Dataset (NLCD) (Vogelman and others, 2001). The NLCD was compiled from LANDSAT satellite Thematic Mapper imagery (circa 1992) with a spatial resolution of 30 meters and supplemented by various ancillary data, where available. The NLCD classification contains 21 land-cover categories with a spatial resolution of 30 meters. The NLCD was produced as a cooperative effort between the USGS and the U.S. Environmental Protection Agency (USEPA) to produce a consistent, land cover layer for the conterminous United States (U.S. Geological Survey, 2000).

\section{Methods of Analysis}

The generalized estimating equations developed for annual and seasonal ground-water recharge were based on multiple-linear-regression analysis using records from between 48 and 55 continuous-record stream-gaging stations. Multiple linear regression is a method of demonstrating that a response (dependent) variable, $Y$, varies with a set of independent variables, $X_{1}-X_{\mathrm{n}}$. The variability, which the response variable exhibits, has two components-a systematic and a random part. The systematic variation of $Y$ can be modeled as a function of the $X$ variables. The random part accounts for the model not exactly describing the behavior of the response variable. A least-squares method is used to estimate the parameters of the model, based on observed values of these variables, by minimizing the sum of squared differences between the actual $Y$ values and the values of $Y$ predicted by the regression equation (Freund and Littell, 2000).

In multiple linear-regression analysis, one or more independent variables (climatic or physical basin characteristics) are statistically related to the dependent variable (ground-water recharge) for a group of stream-gaging stations. The results for this study are annual and seasonal equations for estimating ground-water recharge for ungaged drainage basins. The regression equations take the following form: 
Table 2. Basin characteristics for stream-gaging stations used in the ground-water recharge regression-analysis equations for New Hampshire drainage basins.

[No., number; fig., figure; in., inches; NLCD, National Land Cover Dataset; ${ }^{\circ} \mathrm{F}$, degrees Fahrenheit]

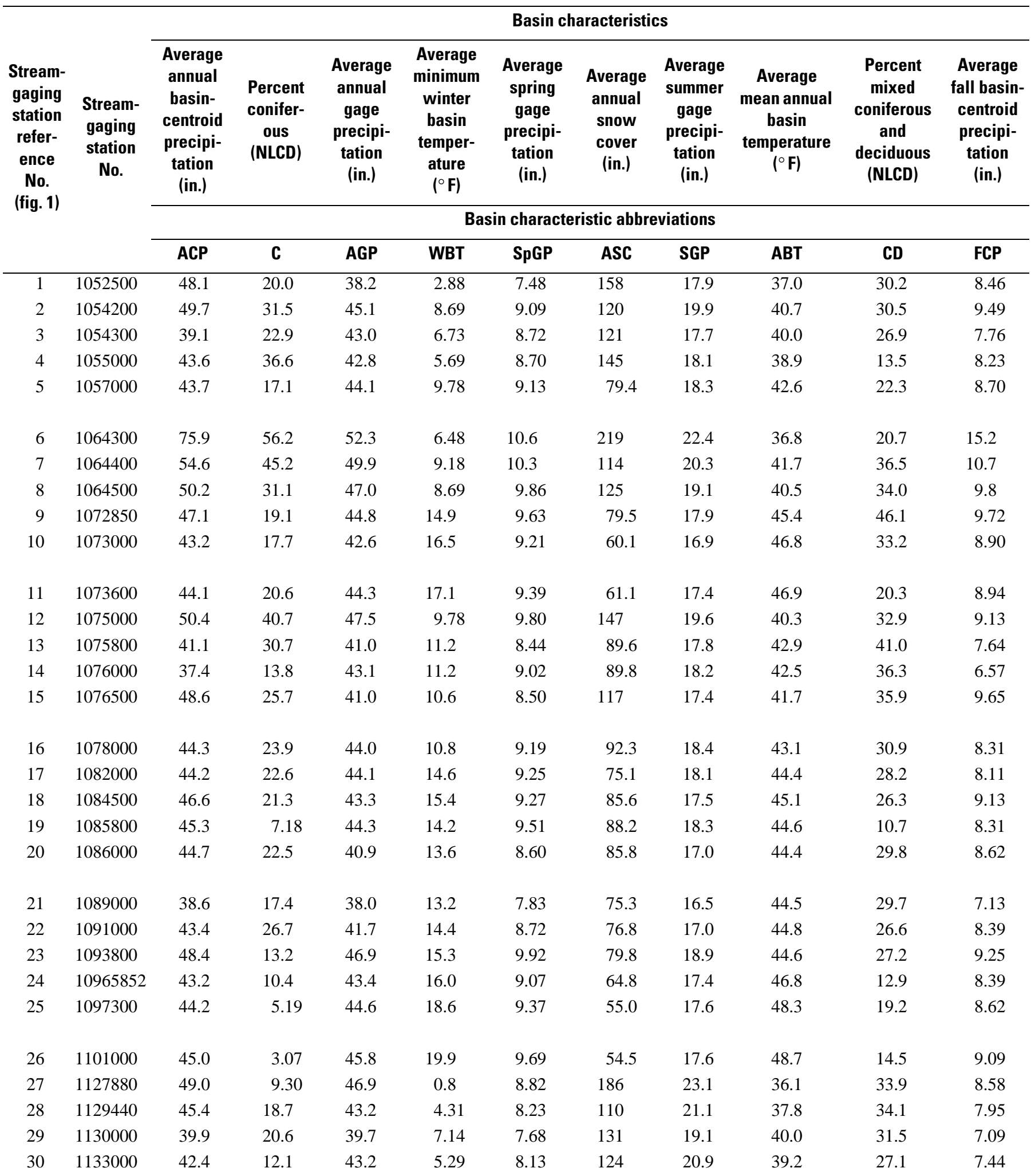


Table 2. Basin characteristics for stream-gaging stations used in the ground-water recharge regression-analysis equations for New Hampshire drainage basins.-Continued

[No., number; fig., figure; in., inches; NLCD, National Land Cover Dataset; ${ }^{\circ} \mathrm{F}$, degrees Fahrenheit]

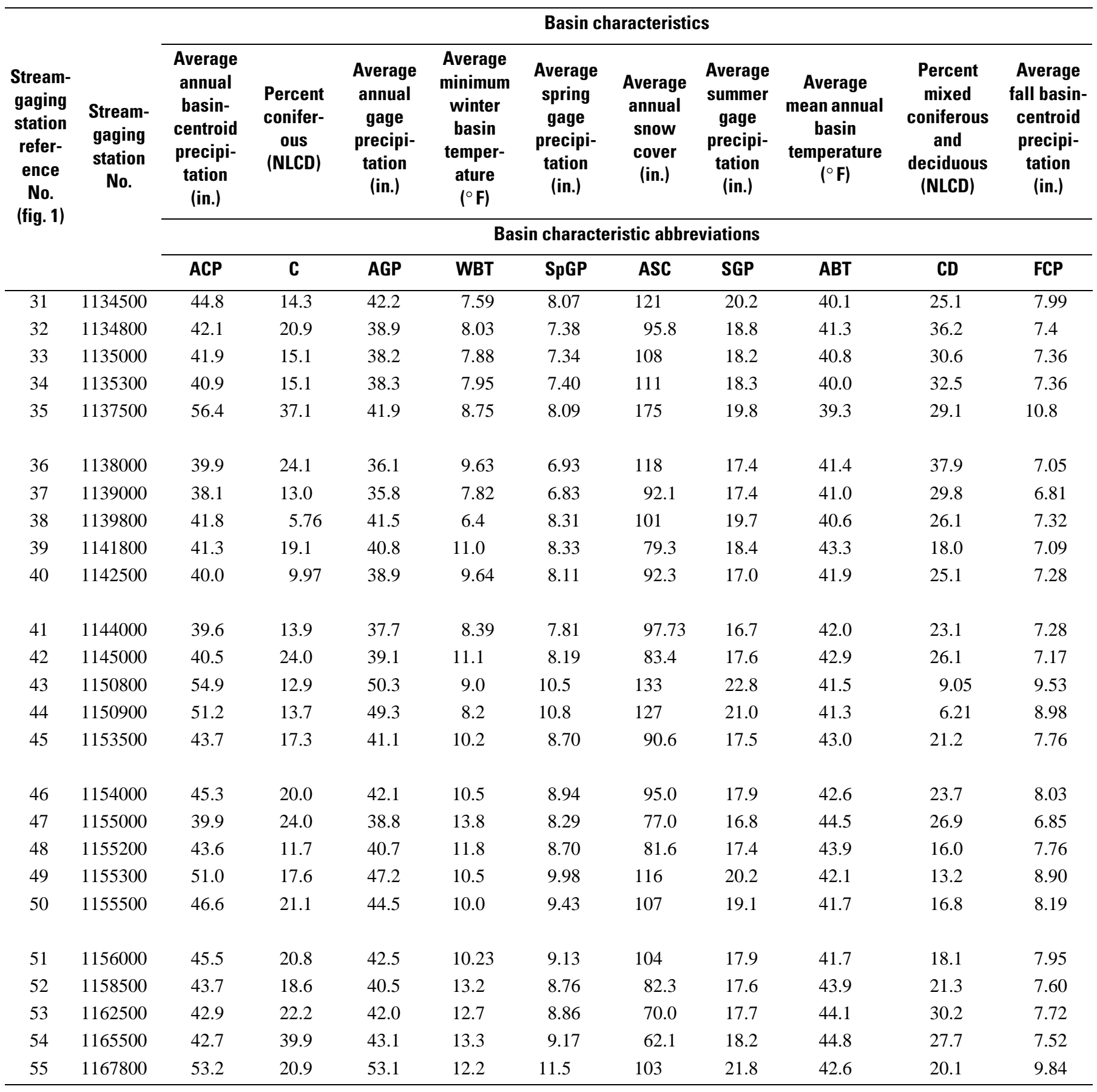




$$
\begin{gathered}
Y_{g(s)}=b_{0, s}+b_{1, s} X_{1, g(s)}+b_{2, s} X_{2, g(s)}+ \\
\ldots+b_{p, s} X_{p, g(s)}+e_{g(s)}
\end{gathered}
$$

where

$$
\begin{aligned}
Y_{g(s)} \quad \begin{array}{l}
\text { is the normalized ground-water } \\
\text { recharge for basin } g \text { during season } s, \\
\text { where } s \text { represents the annual, spring, } \\
\text { summer, fall, or winter seasons, } \\
\text { are the annual and seasonal climatic } \\
X_{l, g(s)} \text { to } X_{p, g(s)} \\
b_{0, s} \text { to } b_{p, s} \\
\text { ore the estimated regression-model } \\
\text { coefficients, }
\end{array}
\end{aligned}
$$

and

$$
e_{g(s)}
$$

is the residual error or difference between the measured and the estimated value of normalized recharge for basin $g$ in season $s$.

Assumptions for use of the regression analysis are that the (1) regression equation describes the relation between the dependent and independent variables, (2) mean of the residual error is zero, (3) variance of the residual error is constant and independent of the values of $X_{n}$, (4) residual errors are normally distributed, and (5) residual errors are independent of one another (Helsel and Hirsch, 2000).

\section{Ordinary-Least-Squares Regression Equations}

Final parameter estimates for the annual and seasonal ground-water recharge regression equations were developed using GLS regression. OLS was necessary for the efficient evaluation of the many possible alternative regression equations. Diagnostic checks were done to test for model adequacy and violations of the assumptions for regression analysis. In addition, plots were made of

a. Predicted values in relation to the residuals to determine if there were any trends in the data,

b. Studentized (standardized) residuals in relation to observation number (stream-gaging station reference number) to determine if there were any unusually large residuals, and

c. Studentized residuals in relation to normal quantile to determine if the residuals were normally distributed. The normal quantile is the expected quantile if the residuals are normally distributed.

\section{Generalized-Least-Squares Regression Equations}

Generalized-Least-Squares (GLS) regression analysis was used to develop the final equations for annual and seasonal ground-water-recharge rates by use of the computer program Generalized-Least-Squares NETwork (GLSNET) (Tasker and Stedinger, 1989). GLS-regression analysis accounts for the differences in the variances of the basin-specific recharge esti- mates, as well as for the cross-correlation of concurrent basinspecific recharge estimates with other stations. According to Tasker and Stedinger (1989), GLS analysis is more appropriate, and provides better results in hydrologic regressions, than OLSregression analysis when the streamflow records at stations are of varying lengths and when concurrent flows at different stations are correlated. Tasker and Stedinger (1989) demonstrated that GLS analysis generally provides the most accurate results for hydrologic regressions as streamflow data are correlated spatially and in time. Weighted-least-squares (WLS) can compensate for differences in record length, but, unlike GLS, it does not compensate for cross-correlation among the stream-gaging stations used in the analysis. The weight given to each station in a GLS analysis is adjusted to compensate for differences in record length among the stations and for spatial correlation. GLS gives less weight to stations with short periods of record and to those stations with concurrent flows that are correlated with other sites. Model precision increases for models with decreasing standard error of estimate and increasing crosscorrelation when GLS regression methods are used instead of WLS regression methods (Stedinger and Tasker, 1985).

Covariance matrices and standard errors were determined using OLS regression analysis. Concurrent record lengths for every pair of stations were determined from GLSNET output determined for a report detailing a stream-gaging network analysis for New Hampshire (Flynn, 2003) using the same streamgaging stations that were used in this study. GLSNET output includes a concurrent record-length matrix, which was altered to begin in 1949. The standard errors and covariance matrices as determined in OLS were used to estimate the variance of prediction for the normalized recharge at each station. These estimates of variance of prediction were used in the GLS regional equation to weight the observations of normalized recharge. The residuals and concurrent record lengths for every pair of stations from 1949 through the last year of record (1998) were determined and applied to come up with an average crosscorrelation to compute the sample covariance of the normalized recharges between sites for the GLS weighting matrix.

\section{Regional Regression for Normalized Annual and Seasonal Recharge Using Generalized-Least-Squares Regression}

A regional regression model is used to estimate normalized recharge as a function of average precipitation and basin (land use) characteristics. A linear model is assumed having the form

$$
\psi=X \beta+\varepsilon,
$$




\section{Streamflow Data of Annual and Seasonal Ground-Water Recharge Rates for Drainage Basins in New Hampshire}

where

$\psi \quad$ is a $(N \times 1)$ column vector of normalized annual or seasonal recharge values,

$X \quad$ is a $(N \times p)$ matrix of known basin characteristics augmented by a column of 1's,

$\beta \quad$ is a $(p \times 1)$ column vector of unknown regression coefficients to be estimated,

and

$\varepsilon \quad$ is a $(N \times 1)$ column vector of errors with $E[\varepsilon]=0$ and $E\left[\varepsilon \varepsilon^{\prime}\right]=I \gamma^{2}$.

The scalar value $\gamma^{2}$ is called the model-error variance, and $N$ is the number of stream-gaging stations in the region.

The operational problem with this model is that the average normalized recharge, $\psi$, from streamflow records must be estimated from available streamflow records that may be relatively short at some sites. At a given site, $\psi$ is estimated by an at-site regression of recharge, $z_{i j}$, at site $i$ in year $j$ against precipitation $w_{i j}$. Each at-site regression is fit by OLS and has the form

$$
z_{i j}=a_{i 0}+a_{i l} w_{i j}
$$

with standard error of estimate $s^{2}{ }_{i}$. The estimate of normalized recharge for a long representative period at site $i, y_{i}$, is

$$
y_{i}=a_{i 0}+a_{i l} \bar{w}_{i}
$$

where

$$
\begin{array}{ll}
\bar{w}_{i} \quad \text { is mean annual precipitation for a } \\
\text { long representative base period at } \\
\text { site } i .
\end{array}
$$

The discharge record length at site $i$ is denoted as $n_{i}$ such that

where

$$
S S_{w}=\sum_{j=1}^{n_{i}}\left(w_{i j}-\bar{w}_{i j}\right)^{2}
$$

$\bar{w}_{i j} \quad$ is the mean of the $n_{i}$ observed annual precipitation values,

and

$S S w \quad$ is the total sum of squared deviations from the mean.

The standard error of $y_{i}$ is

$$
S_{i}=s_{i} \sqrt{\frac{1}{n_{i}}+\left(\frac{\left(\bar{w}_{i}-\bar{w}_{i j}\right)^{2}}{S S_{w}}\right)}
$$

The resulting estimate of $\psi_{i}$, therefore, has a random-error component such that

$$
\psi_{i}=y_{i}-\eta
$$

where

That is

$$
\begin{array}{ll}
\eta_{i} \quad \text { is a random error with } E\left[\eta_{\mathrm{i}}\right]=0 \text { and } \\
\operatorname{Var}\left[\eta_{\mathrm{i}}\right]=S_{\mathrm{i}}^{2},
\end{array}
$$

$y_{i} \quad$ is an unbiased estimate of $\psi$ with a sampling error that is a function of $s_{\mathrm{i}}$ and $n_{\mathrm{i}}$.

Substituting equation 6 into equation 1, in matrix notation the regional regression model is

$$
y=X \beta+\varepsilon+\eta,
$$

with $E[\varepsilon+\eta]=0$ and $E\left[(\varepsilon+\eta)(\varepsilon+\eta)^{\prime}\right]=\Lambda$. The covariance matrix of errors, $\Lambda$, is

$$
\Lambda=y^{2} I+\Sigma
$$

in which the $(N \times N)$ matrix $\Sigma$ has elements of

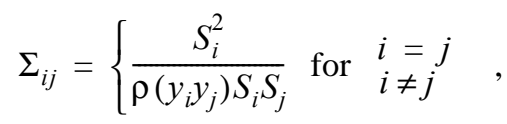

where

$i$ and $j \quad$ are index rows and columns of the matrix,

and

$$
\begin{array}{ll}
\rho\left(y_{i}, y_{j}\right) \quad \text { is the correlation between estimates } \\
\\
\text { of mean annual recharge at sites } i \\
\text { and } j .
\end{array}
$$

A regression model with this error structure was considered by Stedinger and Tasker $(1985,1986)$ in developing an estimated generalized-least squares (EGLS) analysis for regional hydrologic regression. The analysis potentially provides for more accurate estimates of regression coefficients when compared to OLS analysis when sites have different record lengths, given an unbiased model-error estimator and a better description of the relation between hydrologic data and information for hydrologic network analysis and design (Tasker and Stedinger, 1989; and Moss and Tasker, 1991).

The GLS analysis for regional regression of normalized recharge generally proceeds as follows: The $\Sigma$ matrix is estimated by entering the $S_{\mathrm{i}}$ 's from the $N$ at site regressions and using the relation between cross-correlation coefficients from mean annual values and annual values

$$
\rho\left(y_{i} y_{j}\right)=\frac{m_{i j} \rho_{i j}}{\sqrt{n_{i} n_{j}}},
$$


where

$$
\begin{aligned}
& m_{i j} \quad \text { is the concurrent record length } \\
& \text { between } i \text { and } j,
\end{aligned}
$$

and

$$
\begin{aligned}
& \rho_{i j} \quad \begin{array}{l}
\text { is the correlation between concurrent } \\
\text { annual or seasonal recharge values at } \\
\text { the pair of sites. }
\end{array}
\end{aligned}
$$

The value of $\rho_{\mathrm{ij}}$ used to compute $\rho\left(y_{\mathrm{i}}, y_{\mathrm{j}}\right)$ in equation 10 was estimated as 0.25 from sample estimates at every pair of sites with at least 20 years of concurrent record. Once the $\Sigma$ matrix is filled out from the sample data, the EGLS regression estimators of the model parameters, $\beta$, are determined by solving

$$
\left\{X^{\top} \Lambda^{-1} X\right\} \beta=X \Lambda^{-1} y,
$$

with model-error variance $\gamma^{2}$ determined so that

$$
(y-X \beta)^{\prime} \Lambda^{-1}(y-X \beta)=N-p .
$$

\section{Estimates of Annual and Seasonal Ground- Water-Recharge Rates}

For this study, recession-curve displacement was chosen as the method for determining ground-water recharge. The use of recession-curve displacement for determining ground-waterrecharge rates provides a spatial, as well as temporal, average for a particular basin for a particular period of time. When recession-curve-displacement methods are applied to more than one stream-gaging station, and if the stations have different lengths of record, then the resulting set of recharge rates would be inconsistent because of temporal variations in recharge. A common period of data collection for average precipitation was used to adjust the set of recharge rates to eliminate temporal variation. Annual and seasonal regression equations were developed to describe the spatial variation of recharge rates for all of the drainage basins in New Hampshire.

Annual and seasonal basin-specific estimates of groundwater recharge were determined using the recession-curvedisplacement computer program RORA (Rutledge, 1998). RORA estimates the mean rate of ground-water recharge in a basin from an analysis of the streamflow record. Although at many stations, streamflow records were considerably longer; the length of record for the basin specific estimation of groundwater recharge determined in this study ranged from 10 to 50 years. The length of station records used to determine annual and seasonal ground-water-recharge rates was dictated by the length of record of the digital NCDC precipitation-gage data. This was a consequence of regressing basin-centroid precipitation values as determined from the NCDC gage data against the ground-water-recharge values to determine basin-specific estimates of ground-water-recharge rate. The digital NCDC precipitation-gage data were available from 1949 through 1998.

\section{Estimation of Ground-Water-Recharge Rates from Stream-Gaging Station Data}

The estimation of ground-water recharge from streamflow is a process influenced by many contributing factors such as the variable geology and hydraulic properties of the stream channel sediments, the non-steady state of the streamflow, the duration of the streamflow, the changing channel cross section, infiltration differences due to changing hydraulic head during streamflow, and antecedent moisture conditions of the streambed sediments (Savard, 1998).

Streamflow data were initially analyzed by use of the computer program RECESS (Rutledge, 1993) to compute a recession index of streamflow at times when all flow is assumed to be ground-water discharge and when the ground-water head distribution is nearly constant. RECESS uses a repetitive interactive procedure for selecting several periods of continuous recession, determines a best-fit equation for the rate of recession as a function of flow for the selected periods, and then uses this equation to derive a master recession curve that describes the average flow-recession characteristic with time (Rutledge, 1993).

Once the recession characteristics were defined, streamflow data were analyzed using recession-curve-displacement methods (Rutledge, 1998) to determine the average annual and seasonal ground-water-recharge component throughout the length of record. RORA (Rutledge, 1998) was used to estimate the ground-water recharge in a basin from an analysis of the streamflow record. The program is a computerized version of a method of measuring the displacement of the streamflow-recession curve resulting from each recharge event, also known as the Rorabaugh method (Rorabaugh, 1964). The Rorabaugh method is based on the measurement of the change in the total potential ground-water discharge as estimated at critical time after the peak by extrapolation from the pre-peak and post-peak recession periods. The method yields an estimate of the mean rate of ground-water recharge through the analysis of a long period of record (Rutledge, 1993). Recharge rates, as determined by the Rorabaugh method, are representative of an average of the rates for relatively large geographic areas; however, within these geographic areas there may be places where the recharge rate is greater or less than the average rate determined.

Although considerable uncertainty is inherent in the recession index, the analysis of streamflow data used in the APRASA (Appalachian and Piedmont physiographic provinces Regional Aquifer-System Analysis) project (Swain and others, 1991; Rutledge and Mesko, 1996) indicated the estimate of recharge is not particularly sensitive to the index as derived from the program RECESS (A.T. Rutledge, U.S. Geological Survey, written commun., 2000). The median recession index for each station from periods of continuous recession were estimated, in this study, using RECESS. RORA was then used to estimate recharge by designating the median recession index as input to that program. Most of the values of the recession index in the AP-RASA study were between 50 and 120 days. The sensitivity test demonstrated that if the recession index was 
decreased by 50 percent, the recharge estimate would increase by $4-9$ percent. When the recession index was increased by 50 percent, the recharge estimate decreased by $2-4$ percent. In a random sampling of annual and seasonal periods for the 55 stream-gaging stations used in this study, the estimate of recharge was not sensitive to the recession index derived from the program RECESS.

RORA-derived recharge values indicate that seasonal recharge can be positive or negative. Negative recharge indicates regional evapotranspiration from the water table (Barlow and Moench, 1998). If the water table is shallow, negative recharge values may be obtained locally because exfiltration is the dominant mode of water transfer (Simmers, 1988). The boxplots in figures 3 through 7 (back of report) show the variation in the RORA-determined annual and seasonal ground-water recharge for each of the stream-gaging stations used in the analysis. Variations in the ground-water recharge between stations is a result of spatial and temporal differences in climatic characteristics and spatial differences in the basin characteristics.

The RORA method is intended for the analysis of a ground-water-flow system that is characterized by diffuse areal recharge to the water table and ground-water discharge to a stream (Rutledge, 2000). The method is appropriate for the determination of ground-water recharge when most or all of the ground water in the basin discharges to a stream and if a streamgaging station at the downstream end of the basin measures all or most of this outflow (Rutledge, 2000). The Rorabaugh method is based on an ideal flow system in which the aquifer has uniform thickness, hydraulic conductivity, and storage coefficient and the stream fully penetrates the aquifer. In addition, the initial condition set by Rorabaugh (1964) is that the hydraulic head everywhere in the aquifer is the same as the stage of the stream. Recharge is considered to be an instantaneous increase in the hydraulic head applied uniformly throughout the aquifer while the stream stage remains unchanged (Rutledge, 2000). In the Rorabaugh method, the ground-water and surface-water divides are considered to be coincident.

Because RORA is based on the assumption that the entire ground-water-discharge hydrograph is described by Rorabaugh's instantaneous-recharge model, the program does not explicitly allow for the effects of ground-water evapotranspiration (Rutledge, 2000). To minimize errors resulting from ground-water evapotranspiration, the recession index at each station was determined by extracting only those periods of continuous recession for the 6 months of October through March (Rutledge, 1997) when evapotranspiration is lowest.

\section{Nomalization of Ground-Water-Recharge Rates Using Precipitation Data}

A point coverage of precipitation gage locations was generated for New Hampshire, Maine, Vermont, and Massachusetts with the GIS spatial analysis software ARC-INFO (Environmental Systems Research Institute, Inc., 1994) and the annual and seasonal NCDC precipitation data were added to the point coverage. Using these data, average annual and seasonal precipitation values were then determined at each of the drainage-basin centroid and stream-gaging stations for each year of record beginning in 1949, the year in which the NCDC digital data begins. An area/distance weighting methodology called "Natural Neighbor" in ARC-INFO 8.1 (Environmental Systems Research Institute, Inc., 1994) was used to interpolate annual and seasonal precipitation for each year of record at each of the drainage-basin centroids and stream-gaging stations based on the NCDC digital precipitation database TD-3240 file. Similar to Inverse Distance Weighting (IDW), this interpolation method is a weighted-average interpolation method. Instead of finding a value of an interpolated point using all of the input points weighted by their distance, "Natural Neighbors" interpolation creates a Delauney triangulation of the input points and selects the closest nodes that form a convex hull around the interpolation point, then weights their values by proportionate area. Delauney triangulation is a proximal method that satisfies the requirement that a circle drawn through the three nodes of a triangle will contain no other points. In other words, all sample points are connected with their two nearest neighbors to form triangles (Environmental Systems Research Institute, Inc., 1994). This method is a general-purpose interpolation method that does not require parameters such as radius, number of neighbors, or weights to be specified (Environmental Systems Research Institute, Inc., 1994), but is based on the geometry of the network.

Annual and seasonal ground-water recharge varies among drainage basins because of temporal and spatial variation in basin and climatic characteristics (such as annual and seasonal precipitation that is the source of ground-water recharge). An estimate of long-term average annual and seasonal groundwater recharge can be made using recession-curve-displacement methods; however, this estimate is not consistent among stream-gaging stations that have operated during different periods. To ensure a consistent recharge estimate among selected recharge basins, each annual and seasonal RORA-determined ground-water-recharge value was related to each area/distanceweighted NCDC annual and seasonal basin-centroid precipitation (respectively, for each basin) value by a set of basin-specific regression equations. The 275 annual and seasonal drainage-basin-specific regression equations were developed by use of the SAS program, version 8.1 (SAS Institute, Inc., 1994) using OLS regression analysis. The general form of the basinspecific regression equations is

$$
q_{g(s)}=B_{o, g(s)}+B_{1, g(s)} P_{g(s)}+e_{g(s)},
$$


where

$q g(s) \quad \begin{aligned} & \text { is the Rorabaugh-method-determined } \\ & \text { ground-water recharge for basin } g \\ & \text { during season } s, \text { where } s \text { represents } \\ & \text { the annual, spring, summer, fall, or }\end{aligned}$
$\begin{aligned} & \text { winter seasons; } \\ & \text { is the precipitation at the basin cen- } \\ & \text { troid in basin } g \text { during season } s ; \\ & \text { are a set of OLS regression coeffi- } \\ & \text { cients for basin } g \text { during season } s ;\end{aligned}$

and

$e g(s) \quad$ is the residual error between the Rorabaugh-method-determined value and the estimated value of groundwater recharge for basin $g$ during season $s$.

A recharge estimate and the statistical significance of the annual and seasonal regression equations relating ground-water recharge and area/distance-weighted NCDC drainage-basincentroid precipitation for each stream-gaging station was determined. Only coefficients significant at the 5-percent level were maintained in the equations. In some instances, the basin recharge rate was based only on the RORA-determined groundwater-recharge rate as the area/distance-weighted NCDC basincentroid precipitation was not statistically significant.

To help determine the spatial distribution of recharge, temporal variations in recharge were removed by normalizing the estimates of ground-water recharge. For consistency among stations that have operated during different periods, annual and seasonal normalized ground-water recharge was determined by substituting the average annual and seasonal basin-centroid values of precipitation, as determined from 2-kilometer-grid PRISM precipitation data for 1961-90 (Daly, 2000), into each of the annual and seasonal (respectively) basin-recharge equations for the area/distance-weighted NCDC basin-centroiddetermined precipitation values.

The set of annual and seasonal basin-specific regression equations that relate the RORA-determined ground-waterrecharge rate and area/distance-weighted NCDC basin-centroid precipitation for each station location are listed in tables 3-7 (back of report). The general form of these equations is shown in equation 13. Equations in which the independent variable of area/distance-weighted NCDC basin-centroid precipitation was not significant at the 5-percent level were listed as not applicable in tables 3-7 (back of report). Rather than being normalized for 1961-90, the normalized basin-recharge rate for these basins was based only on the RORA-determined ground-waterrecharge rate.

In many cases, the sum of the normalized seasonal groundwater-recharge values in each drainage basin does not equal the value of the normalized annual ground-water recharge. As a long period of record has a greater sampling of the recession index, a much greater confidence is associated with the recession-curve-displacement method for the annual period rather than for the seasonal period. The percent error in the annual drainage-basin ground-water recharge, when compared to the sum of the seasonal drainage-basin ground-water recharge, is shown in table 8.

The estimation equations developed in this study were incorporated into a GIS to produce a "point-and-click" tool for rapidly estimating low-flow, flow-duration (Flynn, 2002), and ground-water-recharge statistics for any unregulated stream reach in the State. A GIS is required to measure the value of the independent variables in the regression equations. As all of the seasonal and the annual ground-water-recharge values will be displayed in the "point-and-click" application that makes use of the regression equations developed in this report, the user has the option of using the sum of the seasonal values rather than the annual value of ground-water recharge. This difference between the annual value of ground-water recharge and the sum of the seasonal values of ground-water recharge represents the error that is inherent in the use of recession-curve displacement methods and the error in the annual and seasonal normalized regression equations. During the winter season (January 1March 15), there were many occurrences in which the independent variable of area/distance weighted NCDC drainage-basincentroid precipitation was not significant at the 5-percent level. The percent error in annual and summed seasonal ground-water recharge is also a reflection of the method of selecting precipitation gages as used to determine the basin-centroid precipitation values. If daily precipitation values at a particular precipitation gage were missing for a season or year, then that gage was not included for that season or year and another nearby precipitation gage was selected in its place (for determination of the basin-centroid precipitation) along with two other precipitation gages using Delauney Triangulation for interpolation of the precipitation value. Since a different precipitation gage would be used for that season and year than that which would be used for the other three seasons, the value of normalized annual ground-water recharge could be slightly different than the sum of normalized seasonal ground-water recharge.

The proportion of normalized drainage-basin recharge to PRISM basin-centroid precipitation for 1961-90 for each annual and seasonal period is shown in figures 8-12 (back of report). The value of average percentage of normalized drainage-basin recharge to PRISM basin-centroid precipitation for each basin is listed in table 8 .

On an annual basis, the average proportion (percentage) of normalized drainage-basin recharge to PRISM basin-centroid precipitation was 47 percent with a standard deviation of 6.75 (table 8). In the winter (fig. 9), the ratio of ground-water recharge to precipitation is greatest on the seacoast of New Hampshire and low in the northern, mountainous sections of New Hampshire. This low ratio is due to increased snowpack and colder temperatures in the mountainous sections. The average proportion of normalized drainage-basin recharge to PRISM basin-centroid precipitation for the winter was 55 percent with a standard deviation of 12.9 (table 8 ). In the spring, snowmelt contributes significantly to ground-water recharge (fig. 10) such that the ratio of ground-water recharge to precipitation is greater than 100 percent for many areas in northern and central New Hampshire. The average proportion of 
Table 8. Values of seasonal and annual basin-centroid precipitation and normalized ground-water recharge and the proportion (in percent) of normalized seasonal and annual ground-water recharge to seasonal and annual basin-centroid precipitation.

[No., number; Location of stream-gaging stations are shown in figure 1 and reference numbers and descriptions of stream-gaging stations are listed in table 1; --, no data]

\begin{tabular}{|c|c|c|c|c|c|c|c|c|c|c|c|c|c|c|c|c|c|}
\hline \multirow{2}{*}{$\begin{array}{c}\text { Stream- } \\
\text { gaging } \\
\text { station } \\
\text { No. }\end{array}$} & \multirow{2}{*}{ River } & \multicolumn{5}{|c|}{ Drainage-basin centroid precipitation } & \multicolumn{5}{|c|}{ Normalized drainage-basin recharge } & \multirow{2}{*}{$\begin{array}{l}\text { Percent error of } \\
\text { annual versus sum } \\
\text { of seasonal basin } \\
\text { recharge values }\end{array}$} & \multicolumn{5}{|c|}{$\begin{array}{l}\text { Proportion (in percent) of normalized drainage- } \\
\text { basin recharge to centroid precipitation }\end{array}$} \\
\hline & & Annual & Winter & Spring & Summer & Fall & Annual & Winter & Spring & Summer & Fall & & Annual & Winter & Spring & Summer & Fall \\
\hline 1052500 & Diamond River & 48.1 & 7.46 & 9.19 & 23.0 & 8.46 & 23.1 & 3.07 & 12.1 & 6.69 & 3.84 & 11.3 & 48.0 & 41.1 & 131.6 & 29.1 & 45.4 \\
\hline 1054200 & Wild River & 49.7 & 8.74 & 10.1 & 21.5 & 9.49 & 20.7 & 4.15 & 10 & 3.8 & 2.93 & 0.87 & 41.7 & 47.5 & 99.2 & 17.7 & 30.9 \\
\hline 1054300 & Ellis River & 39.1 & 6.91 & 7.85 & 16.5 & 7.76 & 18.2 & 3.35 & 10 & 3.22 & 3.08 & 7.97 & 46.6 & 48.5 & 127.3 & 19.5 & 39.7 \\
\hline 1055000 & Swift River & 43.6 & 7.34 & 8.76 & 19.2 & 8.23 & 19.6 & 3 & 10.2 & 4.12 & 3.4 & 5.71 & 45.0 & 40.9 & 116.4 & 21.5 & 41.3 \\
\hline 1057000 & Little Androscoggin River & 43.7 & 7.56 & 8.94 & 18.5 & 8.70 & 18.3 & 3.71 & 8.65 & 3.03 & 3.69 & 4.26 & 41.9 & 49.1 & 96.8 & 16.4 & 42.4 \\
\hline 1064300 & Ellis River & 75.9 & 15.1 & 15.4 & 30.2 & 15.2 & 30 & 3.92 & 13.3 & 9.37 & 4.24 & 2.77 & 39.5 & 26.0 & 86.2 & 31.1 & 27.9 \\
\hline 1064400 & Lucy Brook & 54.6 & 10.4 & 11.3 & 22.2 & 10.7 & 24.9 & 4.54 & 10.5 & 3.85 & 3.99 & 8.11 & 45.6 & 43.8 & 92.6 & 17.3 & 37.3 \\
\hline 1064500 & Saco River & 50.2 & 9.41 & 10.5 & 20.4 & 9.80 & 24 & 4.21 & 11.7 & 3.71 & 3.95 & 1.79 & 47.8 & 44.7 & 111.3 & 18.2 & 40.3 \\
\hline 1072850 & Mohawk River & 47.1 & 8.52 & 9.98 & 18.9 & 9.72 & 23.9 & 5.43 & 7.61 & 1.59 & 4.23 & 21.1 & 50.7 & 63.7 & 76.3 & 8.4 & 43.5 \\
\hline 1073000 & Oyster River & 43.2 & 7.83 & 9.29 & 17.2 & 8.90 & 20.7 & 5.9 & 7.61 & 2.78 & 4.02 & 1.88 & 47.9 & 75.3 & 81.9 & 16.2 & 45.2 \\
\hline 1073600 & Dudley Brook & 44.1 & 8.31 & 9.33 & 17.5 & 8.94 & -- & 3.95 & 5.16 & 1.45 & 2.39 & -- & -- & 47.5 & 55.3 & 8.3 & 26.7 \\
\hline 1075000 & Pemigewasset River & 50.4 & 8.37 & 10.1 & 22.8 & 9.13 & 26.2 & 3.43 & 13.7 & 6.21 & 4 & 4.35 & 52.0 & 41.0 & 135.1 & 27.2 & 43.8 \\
\hline 1075800 & Stevens Brook & 41.1 & 7.01 & 8.35 & 18.1 & 7.64 & 12.3 & 3.01 & 6.03 & 1.69 & 2.36 & 6.42 & 30.0 & 43.0 & 72.2 & 9.3 & 30.9 \\
\hline 1076000 & Baker River & 37.4 & 5.79 & 7.52 & 17.5 & 6.57 & 17 & 3 & 8.74 & 3.26 & 2.81 & 4.76 & 45.4 & 51.8 & 116.2 & 18.6 & 42.7 \\
\hline 1076500 & Pemigewasset River & 48.6 & 8.92 & 10.1 & 20.0 & 9.65 & 22.1 & 3.65 & 10.4 & 4.92 & 4.45 & 5.97 & 45.5 & 40.9 & 103.0 & 24.6 & 46.1 \\
\hline 1078000 & Smith River & 44.3 & 7.78 & 9.39 & 18.7 & 8.31 & 21 & 4.08 & 8.86 & 3.87 & 3.58 & 2.90 & 47.4 & 52.5 & 94.4 & 20.7 & 43.1 \\
\hline 1082000 & Contoocook River & 44.2 & 8.33 & 9.23 & 18.5 & 8.11 & 21.3 & 5.07 & 8.38 & 3.62 & 3.56 & 3.51 & 48.2 & 60.9 & 90.8 & 19.6 & 43.9 \\
\hline 1084500 & Beards Brook & 46.6 & 8.64 & 9.90 & 19.1 & 9.13 & 22.9 & 4.66 & 9.1 & 3.01 & 4.35 & 7.77 & 49.2 & 53.9 & 91.9 & 15.8 & 47.6 \\
\hline 1085800 & West Branch Warner River & 45.3 & 7.95 & 9.76 & 19.1 & 8.31 & 22.7 & 5.4 & 9.38 & 3.58 & 4.04 & 1.32 & 50.1 & 67.9 & 96.1 & 18.7 & 48.6 \\
\hline 1086000 & Warner River & 44.6 & 8.31 & 9.61 & 18.1 & 8.62 & 24 & 4.94 & 10.4 & 3.09 & 4.26 & 5.46 & 53.8 & 59.5 & 108.3 & 17.0 & 49.4 \\
\hline 1089000 & Soucook River & 38.6 & 6.71 & 8.01 & 16.9 & 7.13 & 16.4 & 4.32 & 6.55 & 2.62 & 2.96 & 0.30 & 42.5 & 64.4 & 81.8 & 15.5 & 41.5 \\
\hline 1091000 & $\begin{array}{l}\text { South Branch Piscataquog } \\
\text { River }\end{array}$ & 43.4 & 8.23 & 9.13 & 17.7 & 8.39 & 20 & 5.41 & 7.99 & 2.62 & 3.66 & 1.60 & 46.1 & 65.7 & 87.5 & 14.8 & 43.6 \\
\hline 1093800 & Stony Brook Tributary & 48.4 & 9.15 & 10.3 & 19.6 & 9.25 & 25.1 & 6.14 & 9.34 & 3.71 & 4.9 & 4.02 & 51.8 & 67.1 & 91.1 & 18.9 & 53.0 \\
\hline 1097300 & Nashoba Brook & 44.2 & 8.82 & 9.29 & 17.4 & 8.62 & 20.1 & 6.71 & 6.66 & 2.82 & 3.82 & 0.45 & 45.5 & 76.1 & 71.7 & 16.2 & 44.3 \\
\hline 1101000 & Parker River & 45.0 & 9.02 & 9.49 & 17.4 & 9.09 & 26.1 & 7.82 & 8.77 & 3.95 & 4.84 & 2.76 & 58.1 & 86.7 & 92.4 & 22.8 & 53.2 \\
\hline 1127880 & Big Brook & 49.0 & 7.28 & 9.21 & 23.9 & 8.58 & 28.9 & 4.47 & 12.4 & 10.2 & 4.82 & 10.3 & 59.0 & 61.4 & 134.6 & 42.6 & 56.2 \\
\hline 1129440 & Mohawk River & 45.4 & 7.03 & 8.68 & 21.8 & 7.95 & 19.2 & 4.1 & 6.99 & 5.45 & 4.07 & 7.34 & 42.3 & 58.3 & 80.5 & 25.0 & 51.2 \\
\hline 1130000 & Upper Ammonoosuc River & 39.9 & 6.28 & 7.85 & 18.6 & 7.09 & 20.7 & 3.27 & 10.3 & 3.18 & 2.55 & 6.76 & 51.9 & 52.1 & 131.1 & 17.1 & 36.0 \\
\hline
\end{tabular}


Table 8. Values of seasonal and annual basin-centroid precipitation and normalized ground-water recharge and the proportion (in percent) of normalized seasonal and annual ground-water recharge to seasonal and annual basin-centroid precipitation.-Continued

[No., number; Location of stream-gaging stations are shown in figure 1 and reference numbers and descriptions of stream-gaging stations are listed in table 1; --, no data]

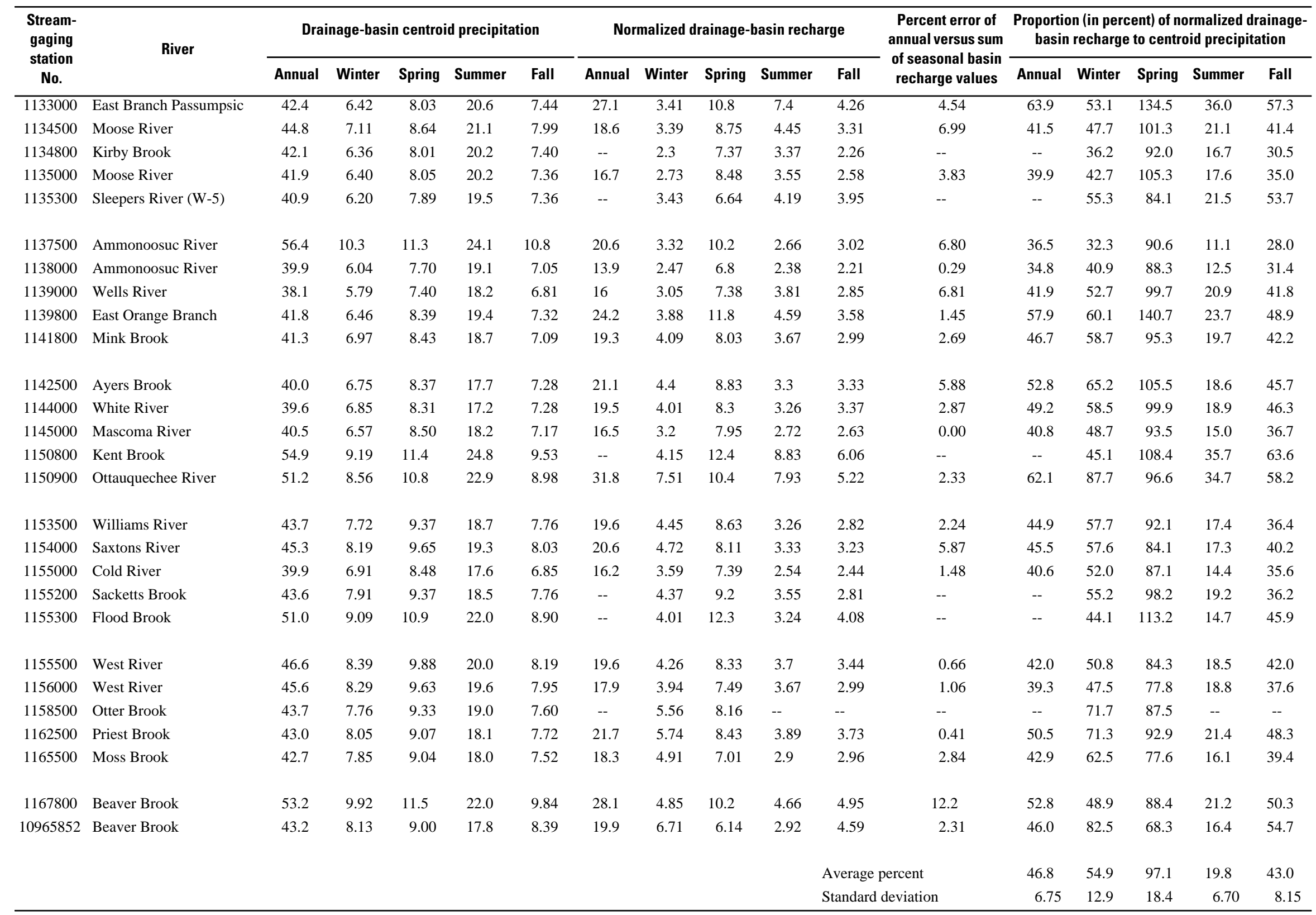


normalized drainage-basin recharge to PRISM basin-centroid precipitation for the spring was 97 percent with a standard deviation of 18.4 percent (table 8 ). In the summer, ground-water recharge decreases (fig. 11). The ratio of ground-water recharge to precipitation is greater in the mountainous areas in the northern part of New Hampshire than other areas in the State during this season. The average proportion of normalized drainagebasin recharge to PRISM basin-centroid precipitation for the summer was 20 percent with a standard deviation of 6.7 percent (table 8). In the fall, the ratios of ground-water recharge to precipitation are similar but somewhat lower and more spatially variable than those for the annual period. For the fall, areas in the northwest and southeast of the study area tend to have the greatest proportion of ground-water recharge to precipitation (fig. 12). The average proportion of normalized drainage-basin recharge to PRISM basin-centroid precipitation for the fall was 43 percent with a standard deviation of 8.2 percent (table 8 ).

\section{Generalized Estimate of Drainage-Basin Ground- Water-Recharge Rates Using Climatic and Basin Characteristics Data}

Ordinary Least Squares (OLS) regression analysis was done using the SAS (Statistical Analysis System) computer program, version 8.1 (SAS Institute, Inc., 1994) to initially select climatic and basin characteristics for estimation of normalized annual and seasonal ground-water recharge. This analysis provided a generalized estimate of ground-water recharge in New Hampshire.

No significant trends were detected in the data and all of the residuals were normally distributed. For the annual period, the station at Dudley Brook (number 1073600) had an unusually large studentized residual and was eliminated from the ground-water-recharge regression analysis for the annual period only. The studentized residual for Dudley Brook was large but not unusually large for the fall and spring periods and was not eliminated for these two seasons.

Annual and seasonal regression equations were developed using GLS regression to relate normalized ground-water recharge at 55 stream-gaging stations to basin and climatic characteristics in the form of 93 potential explanatory variables (Appendix 1). These equations can be used to estimate groundwater recharge for the unregulated stream-gaging station drainage basins used in the regression analysis, as well as for other unregulated, ungaged basin locations.

Because of the large number of basin characteristics (93) to be analyzed as potential independent variables in the annual and seasonal ground-water-recharge regression equations, an automated procedure was required to aid in the selection of a subset of independent variables for the determination of the dependent variable in each of the final regression models. A variable-selection algorithm also was required to assist in determining the combination of independent variables that provided the best estimates of the dependent variable in the regression equations. To accomplish this, a stepwise-regression procedure was used within the SAS program, version 8.1 (SAS Institute, Inc., 1994) to aid in identifying which independent variables were to be included in the regression equations. The stepwise method is a modification of the forward-selection method, in which variables already in the model do not necessarily remain in the model. Variables are added one at a time to the model with the $F$-statistic (mean square for the model divided by the mean square for error) used to test for significance at a predefined level. In this study, the significance level was set at 0.05 . After the addition of each new variable, the stepwise method assessed all of the variables already included in the model and deleted any variable that did not produce an $F$-statistic significant at the selected confidence level. Only after the statistical significance of each independent variable was determined, and those that were statistically insignificant at the specified significance level of 5 percent were eliminated, could another variable be added to the model.

After the statistically significant independent variables (at the 95-percent confidence level) were determined for each of the annual and seasonal ground-water-recharge statistics, an allpossible-regression algorithm called RSQUARE was run in SAS. The RSQUARE method is a useful linear-regression tool for exploratory-model building as it assists in identifying subsets of independent variables that best predict a dependent variable in a given sample (SAS Institute, Inc., 1994). This algorithm examines all of the possible combinations of the independent variables and ranks them according to decreasing order of $R^{2}$ (fraction of the variance explained by the regression) magnitude for the given sample. Using this output of ranked $R^{2}$, the best combination of independent variables was tested for inclusion in the final regression equations. The test included using minimization of Mallow's $C p$ statistic (Cavalieri and others, 2000; Ries and Friesz, 2000) as one of the selection criteria. The subsets were further analyzed using OLS regression analyses to select a final model for each ground-waterrecharge statistic. The final regression models were selected based upon consideration of the following statistical parameters:

1. Mallow's $C p$ statistic: a measure of the total squared error for a subset model containing $n$ independent variables (Freund and Littell, 2000). Mallow's $C p$ is an indicator of model bias (Cavalieri and others, 2000), in which models with a large $C p$ are biased because they contain predictors that are not important in the population;

2. Mean Square Error (MSE): the precision of the biased estimate determined as the square of the bias plus the variance (Freund and Littell, 2000), also known as the sample model error variance of the estimates for the stream-gaging stations included in the analysis (Ries and Friesz, 2000);

3. $\quad$ Adjusted $R$ Squared $\left(R_{a d j}^{2}\right)$ : an alternative to $R$-Square $\left(R^{2}\right)$, in which the percentage of variation in the dependent variable can be explained by the variation of the independent variables in the model. In contrast to $R^{2}$, $R^{2}{ }_{a d j}$ is adjusted for the number of parameters in the 
model (number of stream-gaging stations and number of independent variables in the regression analysis) (Freund and Littell, 2000);

4. Predicted REsidual Sum of Squares (PRESS): the sum of squares of residuals using models obtained by estimating the equation with all other observations (Freund and Littell, 2000) and is an estimate of the prediction error sum of squares. The PRESS statistic measures how well the regression model predicts the $i^{\text {th }}$ observation as though it were a new observation (Cavalieri and others, 2000).

In addition to the above statistical criteria for selecting the best combination of independent variables for the final regression models, independent variables were selected based on whether they (1) made hydrologic sense, (2) explained a significant amount of the variability of the dependent (response) variable (ground-water-recharge statistic), and (3) could be easily measured using a GIS.

Regression equations were developed, using SAS software (SAS Institute, Inc., 1994), to determine basin-specific annual and seasonal ground-water-recharge rates from the selected independent variables and the normalized estimates of groundwater recharge. The independent variables selected for the final models were statistically significant at the 95-percent confidence level. This was accomplished by determining that the $p$-value of the test $F$-statistic was less than alpha $=0.05$ (Cavalieri and others, 2000). In addition to statistical criteria, the sign (positive or negative) of all of the regression coefficients had to make hydrologic sense as related to ground-water recharge.

Diagnostic checks were performed to test for model adequacy and violations of the assumptions for regression analysis. Regression-equation independent variables that are highly intercorrelated result in a duplication of the information contained in those variables and prediction equations that are likely to be unreliable. To test for this condition, known as multicollinearity, variance-inflation factors (VIF) were computed for each variable. A VIF expresses the ratio of the actual variance of the coefficient of the predictor variable to its variance if it was independent of the other predictor variables (Cavalieri and others, 2000) and is a measure of how multicollinearity increases the instability or variance of the linear-regression coefficient estimates (Freund and Littell, 2000). VIF values are computed as the inverse of the correlation matrix of the predictor variables. A value exceeding 10 indicates that a predictor variable is so highly correlated to other predictor variables that it is an unreliable predictor and should not be included in the estimation equation as the equation may be unstable. None of the predictor variables retained in the prediction models for this study had VIF values greater than 10 .

Other diagnostic checks for model adequacy and violations of assumptions in regression analysis included the identification of influential observations. Influential observations are data that substantially change the fit of the regression equation. Three diagnostic statistics were computed to help identify influential observations. These statistics were
1. Rstudent (studentized) residuals: the ordinary residuals divided by their standard errors, determined from the difference between the observed dependent variable and the predicted value of the independent variable excluding the $i^{\text {th }}$ observation from the regression analysis (Freund and Littell, 2000); and

2. DFFITS: the standardized difference between predicted values for the $i^{\text {th }}$ observation obtained by the equation estimated by all observations and the equation estimated from all observations excluding the $i^{\text {th }}$ observation (Freund and Littell, 2000).

Ten of the 93 basin characteristics were selected because of their statistical significance in predicting annual and seasonal ground-water recharge. They include

- Average mean annual basin temperature (ABT), in degrees Fahrenheit, is the annual basin average mean temperature from 2-kilometer-grid PRISM (Daly, 2000) data for 1961-90.

- Average minimum winter basin temperature (WBT), in degrees Fahrenheit, is the winter basin average minimum temperature from 2-kilometer-grid PRISM (Daly, 2000) data for 1961-90.

- Coniferous Forest (C), in percent, represents the portion of the basin that is classified as coniferous from NLCD data (Vogelman and others, 2001) and is defined as those areas dominated by trees where 75 percent or more of the tree species maintain their leaves all year. Canopy is never without green foliage;

- Mixed Coniferous/Deciduous Forest (CD), in percent, represents the percent of the basin that is classified as mixed coniferous and deciduous from NLCD data (Vogelman and others, 2001) and is defined as those areas dominated by trees where neither deciduous nor coniferous trees represent more than 75 percent of the cover present;

- Mean annual (AGP), spring (SpGP) and summer (SGP) gage precipitation, in inches, is the annual, spring and summer precipitation determined at the stream-gaging station from 2-kilometer-grid PRISM data for 1961-90;

- Mean annual (ACP) and fall (FCP) basin-centroid precipitation, in inches, is the annual and fall season precipitation determined at the centroid of the basin from 2-kilometer-grid PRISM data for 1961-90.

- Mean annual snowcover (ASC), in inches, is the mean annual basin average snowfall for each of the basins based on monthly data acquired from 2-kilometer-grid PRISM data for 1961-90.

The annual and seasonal normalized ground-water recharge, the GLS regression equation predicted values, the standard error of prediction at each stream-gaging station used in the development of the regression equations and the 
90-percent prediction interval are included in tables 9-13 (back of report). The standard error of prediction is a measure of the scatter about the computed regression line plus the error in estimating the regression line from the data. Thus, the standard error of prediction takes into account that the regression coefficients are estimated from observed data and as such contribute to the uncertainty of the model. The 90-percent prediction interval defines the range of uncertainty associated with the predicted values, which is indicated with a 90 -percent probability that the true value of the ground-water-recharge statistic is between the upper and lower values as listed in tables 9-13 (back of report).

A value of $21.0 \mathrm{in}$. was obtained for the average annual normalized rate of ground-water recharge, for the basins used in the analysis, based on GLS regression analysis of selected basin characteristics and RORA-derived ground-water-recharge estimates adjusted for the average precipitation during 19611990. The average winter ground-water recharge was 4.3 in., average spring ground-water recharge was 9.0 in., average summer ground-water recharge was 4.0 in., and average fall groundwater recharge was 3.6 in. Annual normalized ground-water recharge ranged from 12.3 to 31.8 in., normalized ground-water recharge for winter ranged from 2.30 to $7.82 \mathrm{in}$., for spring ranged from 5.16 to 13.7 in., for summer ranged from 1.45 to $10.2 \mathrm{in}$., and for fall ranged from 2.21 to $6.06 \mathrm{in}$. The GLSdeveloped regression equations for annual and seasonal groundwater recharge are presented in table 14 along with the number of stream-gaging stations used in the analysis and several measures of model adequacy.

\section{Ground-Water-Recharge Regression Equations}

Ten basin characteristics were selected as independent variables in the annual and seasonal ground-water-recharge regression equations given their statistical significance based on several statistical parameters that evaluated which combination of basin characteristics contributed the most to the predictive power of the models. To determine the regression equation ground-water-recharge rates, a GIS is required to measure the values of the independent variables used in this study.

\section{Regression Model Adequacy}

The adequacy of the generalized ground-water-recharge regression equations in table 14 was measured using the following statistics:

1. The Mean Square Error (MSE): an estimate of the variance of the random error term for the full model. It is determined from the error sum of squares (variation in the dependent variable not explained by the model) divided by the error degrees of freedom (the number of independent variable parameters minus one) (Cavalieri and others, 2000).

2. The Average Prediction Error (APE): an overall measure of how accurately the regression model can predict ground-water recharge for ungaged sites where the

Table 14. Summary of regression equations and measures of model adequacy for estimating ground-water-recharge statistics at selected New Hampshire stream-gaging stations.

\begin{tabular}{|c|c|c|c|c|c|}
\hline Statistic & Regression equation & $\begin{array}{l}\text { No. of stream- } \\
\text { gaging stations }\end{array}$ & $\begin{array}{l}\text { Average model } \\
\text { MSE } \\
\text { (in.) }\end{array}$ & $\begin{array}{l}\text { APE } \\
\text { (in.) }\end{array}$ & $\underset{\text { (percent) }}{R^{2} \text { adj }}$ \\
\hline \multicolumn{6}{|c|}{ Ground-water recharge-Generalized-Least-Squares Regression equations } \\
\hline Winter & $-3.485+0.160(\mathrm{AGP})+0.168(\mathrm{WBT})-0.041(\mathrm{C})$ & 55 & 0.39 & 0.67 & 67 \\
\hline Spring & $-1.544+0.721(\mathrm{SpGP})+0.045(\mathrm{ASC})-0.032(\mathrm{C})$ & 55 & 1.11 & 1.11 & 63 \\
\hline Summer & $3.725+0.573(\mathrm{SGP})-0.223(\mathrm{ABT})-0.039(\mathrm{CD})$ & 54 & 1.01 & 1.05 & 57 \\
\hline Fall & $0.389+0.499(\mathrm{FCP})-0.049(\mathrm{C})$ & 54 & .30 & .57 & 48 \\
\hline Annual & $-1.932+0.589(\mathrm{ACP})-0.176(\mathrm{C})$ & 48 & 6.40 & 2.63 & 53 \\
\hline
\end{tabular}


3. average is taken over prediction sites with $X$ variables identical to the observed ground-water-recharge data. APE represents an estimate of the average squared-model error for the $n$ sites plus an estimate of the average squared error due to estimating the true model parameters from a sample of data.

4. Adjusted $R$ Squared $\left(R^{2}{ }_{a d j}\right)$ : an alternative to $R$-Square $\left(R^{2}\right)$, in which the percentage of variation in the dependent variable can be explained by the variation of the independent variables in the model. $R_{a d j}^{2}$ is adjusted for the number of parameters in the model (number of stream-gaging stations and number of independent variables in the regression analysis) (Freund and Littell, 2000);

The GLS model allows the weight given to each site in the regression analyses to be adjusted for cross correlation among all of the concurrent streamflows of the sites and for differences in record lengths. For GLS regression, the variance of the errors for an observation, which in this case is the ground-waterrecharge statistic, is estimated as a function of the error in the regression model and the error in the estimate of the true value of the ground-water-recharge statistic. The error in the calculated stream-gaging station ground-water-recharge statistic is estimated as a function of the record length, variance of the annual events, and cross correlation between the statistics. As a result, it would be inappropriate to use the equally weighted residuals in a GLS model to calculate a measure of predictive accuracy. Instead, the APE is used as a measure of the predictive accuracy of the GLS regression equations (table 14). The APE of the regression model is a measure of how well the regression equations will estimate ground-water recharge when applied to ungaged drainage basins. The APE was determined for the GLS-determined annual and seasonal ground-waterrecharge regression equations by computing the square root of the sum of the average squared model error for the $n$ sites and the average squared error due to estimating true model parameters from sample data.

\section{Physical Basis for the Independent Variables in the Regression Equations}

Recharge to a drainage basin is primarily a function of precipitation, whereas storage and discharge from a basin are controlled primarily by the physical characteristics of the basin (Hayes, 1991). Evapotranspiration and runoff rates are all affected by land use and these affect ground-water-recharge conditions. The drainage-basin characteristics of percent coniferous forest and percent-mixed coniferous and deciduous forest were found to be statistically significant variables in the ground-water-recharge regression equations and reflect the effect of interception, evapotranspiration, infiltration, and runoff rates on ground-water recharge. These two basin characteristics are inversely related to ground-water recharge. The variable of percent mixed coniferous and deciduous forest was found to be significant only for the summer season (June 1October 31), whereas the variable percent coniferous forest was found to be significant in each of the other seasons. The statistical significance of these two basin characteristics supports the concept that evapotranspiration and interception reduce flows and ultimately ground-water recharge by capturing ground water that would have otherwise remained as ground water or discharged to streams. Evapotranspiration results in a major loss of water from drainage basins. It dominates the water balance and controls soil moisture content, ground-water recharge, and streamflow. More than two-thirds of the precipitation falling on the conterminous United States is returned to the atmosphere through evaporation from plants and surface water (Dunne and Leopold, 1978). According to Dunne and Leopold, coniferous trees intercept slightly more rainfall than deciduous trees because coniferous trees have greater masses of foliage and branches throughout the year than deciduous trees and because their needles can hold more interception storage than broad leaves. In the summer, the combined effect of mixed coniferous and deciduous forest was found to be a more significant variable in the ground-water-recharge regression equation than the variable of coniferous forest alone as there is more canopy for interception and greater evapotranspiration during this season. Over the long term, canopy interception was determined to be greater under conifers than under broad-leaf hardwoods. Dunne and Leopold (1978) presumed that this was a result of the high density of conifers in New Hampshire and possibly because of the more frequent occurrence of light rains and snows, which are more fully intercepted in coniferous forests.

The climatic characteristic of average basin temperature for 1961-90 was significant for the winter (January 1-March 15) and summer (June 1-October 31). This variable, which is directly related to ground-water recharge for the winter season and indirectly related to ground-water recharge for the summer season, reflects the basin latitude and elevation, which in turn reflects the prevalence of coniferous and deciduous forest cover. Average basin temperature affects the rate of evaporation in a particular basin. During the winter, cold temperatures result in less ground-water recharge as a result of the accumulation and storage of precipitation within the snowpack. During the summer, water requirements for transpiration increase dramatically and warm temperatures increase evaporation from surface waters, resulting in a decrease in the rate of ground-water recharge.

The climatic characteristic of average annual snowcover for 1961-90 was significant for the spring (March 16-May 31) ground-water-recharge regression equation as high spring flows occur in New England during March, April, and May as a result of melting snowpack and concurrent precipitation resulting in more water available for ground-water recharge. In general, flows are greater in March and April in the streams in southern New Hampshire and are greater in April and May in the streams in central and northern New Hampshire (Hammond and Cotton, 1986). 


\section{Streamflow Data of Annual and Seasonal Ground-Water Recharge Rates for Drainage Basins in New Hampshire}

\section{Uncertainties in Determining Ground-Water Recharge}

The Rorabaugh method was used to determine groundwater recharge in this study. This method is based on an ideal flow system in which the aquifer has uniform thickness, hydraulic conductivity, and storage coefficient; the stream fully penetrates the aquifer; the hydraulic head everywhere in the aquifer is the same as the stage of the stream; and the ground- and surface-water divides are considered to be coincident. Because of these assumptions, it is recognized that there is some error inherent in the estimation of ground-water recharge with this method, as well as with other estimation methods.

Indirect and direct methods are available to estimate ground-water recharge to aquifers. Indirect methods include an estimate of the recharge rate based on the measurement or calculation of the ground-water-discharge rate. This method is based on the steady-state concept that the average rate of ground-water recharge equals the average rate of ground-water discharge over an extended period of time (Knott and Olimpio, 1986). The reduction of flow along a stream reach also can be used to estimate recharge from streamflow losses. The measurement of flow at various locations in the stream can indicate directly the loss of water from the channel or amount of recharge contributed by the stream. A water-balance technique is an indirect method to estimate ground-water recharge, where water loss by evapotranspiration is estimated and subtracted from measured precipitation to calculate ground-water recharge during that same time period (Thornthwaite and Mather, 1957). Other indirect methods include numerical simulation, chemical tracer studies, tritium isotopic studies, studies of ground-waterlevel fluctuations, derivation of empirical relations on the basis of precipitation data, and studies based on hydrograph separation of streamflow records (Holtschlag, 1997). Hydrographseparation techniques are used to analyze streamflow data to determine base flow, which is typically derived largely from ground-water discharge. If it is assumed that there is no longterm change in the amount of ground water in storage, groundwater discharge, as indicated by base flow, equals the amount of ground-water recharge over the basin area contributing the low flow (Vecchioli and others, 1990). Some forms of groundwater discharge that would need to be considered in estimating ground-water recharge from ground-water discharge include withdrawals by wells and evapotranspiration from the water table (Vecchioli and others, 1990).

Direct methods of measuring ground-water-recharge rates are difficult. These methods include, but are not limited to, the use of closed-bottom lysimeters buried beneath the root zone and tensiometers. If it is assumed that low flow is equal to base flow (portion of streamflow attributable to ground-water flow), ground-water discharge can be measured during periods of low flow. Discharge also can be determined using Darcy's law, assuming that the estimated hydraulic conductivity and elevation of the water table are correct (Knott, 1986).

In a study such as this, the true value against which to evaluate a ground-water-recharge estimate, and the method used, is not known. This study contains upland basin-recharge rates that are higher than those determined for till and bedrock in a study conducted in Maine by Morrissey (1983). In that study, the water year of 1981 (October 1, 1980-September 30, 1981) was used to estimate ground-water recharge for the Little Androscoggin River near South Paris (gage 1057000). This drainage basin consists primarily of till. The precipitation for the calendar year of 1980 (42.9 in.) was less than the average annual precipitation (from 1949 to 1998) of 49.8 in., with the late fall of 1980 being particularly dry. The 1981 calendar year precipitation of 48.3 in. was slightly below average. However, this value is for the calendar year and not the water year. According to Morrissey (1983), the National Weather Service determined precipitation at West Paris, Maine was 39.4 in. for the 1981 water year. Precipitation for November 1, 1980, through May 31, 1981, was 19.5 in. The average precipitation for November $1^{\text {st }}$ through May $31^{\text {st }}$ from 1948 to 1998 was $26.1 \mathrm{in}$. This is approximately 25 percent less precipitation than average for this period. Much of the precipitation for the calendar year of 1981 came in the late summer and fall of 1981. Before 1981, precipitation conditions were below normal.

Morrissey assumed that lateral recharge from till to the aquifer is equal to the ground-water runoff from till-covered areas. The ground-water component of runoff was determined for the 1981 water year for the station on the Little Androscoggin River near South Paris using a hydrograph separation method described by Meinzer and Stearns (1929). The resulting annual ground-water-recharge estimate of 7.4 in. is approximately 19 percent of total precipitation for the 1981 water year. The current study estimated an annual recharge rate of approximately $20 \mathrm{in}$. for the 1981 water year. This estimate of groundwater recharge is approximately 51 percent of total precipitation for the 1981 water year. The normalized recharge rate for the Little Androscoggin River Basin was determined to be $18.3 \mathrm{in} / \mathrm{yr}$.

STATSGO (STATe Soil GeOgraphic) data (Schwarz and Alexander, 1995) was designed primarily for regional, multicounty, river basin, State and multistate management, and resource planning and monitoring. Although it is a generalized estimate derived from more detailed soil survey maps, according to STATSGO data upstream from station 1057000, the Little Androscoggin River Basin, has a mean permeability of 4.189 inches per hour. The 100-year, 24-hour rainfall is approximately $7 \mathrm{in}$. and the 100-year, 1-hour rainfall is approximately 2.25 in. for the Little Androscoggin River Basin (U.S. Department of Commerce Weather Bureau, 1961). On the basis of these values, large precipitation events in the Little Androscoggin River Basin are capable of infiltrating and the permeability of the till would not be a factor leading to overland flow and thus a loss of recharge to the aquifer.

Morgan and Jones (1995) conducted a study of the effects of ground-water withdrawals on discharge to streams and springs in small basins typical of the Puget Sound Lowland in Washington State. In their study, reference is made to a written communication (1993) with J.J. Vaccaro (U.S. Geological Survey) in which permeameter measurements of hydraulic conductivity were made in till and showed a range from 0.0002 to 
$53 \mathrm{ft} /$ day. Both this range and the median, $0.12 \mathrm{ft} / \mathrm{d}$, are similar to values reported for till in southern New England, where the range and median were $0.00023-96 \mathrm{ft} / \mathrm{d}$ and $0.3 \mathrm{ft} / \mathrm{d}$, respectively (Melvin and others, 1992). Water budgets were determined for 26 basins and the mean annual precipitation was determined to range from 25-61 in/yr. The range of recharge estimates was from 5 to $29 \mathrm{in} / \mathrm{yr}$. Vaccaro estimated that the average annual recharge in areas underlain by till and other finegrained deposits was $17.5 \mathrm{in}$. In the simulation used in Morgan and Jones (1995), a mean annual precipitation of $44 \mathrm{in} / \mathrm{yr}$ and a recharge rate of $18 \mathrm{in} / \mathrm{yr}$ were used in the areas where the less permeable till was exposed. This recharge rate is similar to the $18.3 \mathrm{in}$. of average annual recharge for the primarily till basin of Little Androscoggin River upstream from USGS stream-gaging station 1057000 with the precipitation being slightly less than the average precipitation of $49.8 \mathrm{in} / \mathrm{yr}$ for this area.

\section{Limitations on the Use of Regression Equations}

The regression equations presented in this report are limited in application by the range of the basin-characteristic data used to develop the equations and by the accuracy of the estimates. These equations should be used with caution when determining ground-water-recharge statistics at ungaged sites with basin characteristics that are beyond the range of those used to develop the regression equations. The ranges of the basincharacteristic data used to develop the ground-water-recharge regression equations are listed in table 15 . The accuracy of the estimates when basin characteristics are within the ranges of those sites used in the regression analysis are listed in table 14.
The use of these regression equations requires that the physical and climatic basin characteristics be determined within a GIS using the same datasets (Appendix 1) that were used to develop the equations outlined in this report.

A GIS computer application tool is planned that will provide ground-water-recharge statistics from a database for gaged and ungaged sites in New Hampshire by measuring the necessary basin characteristics for a user-selected site from digital map data using ArcView GIS (Environmental Systems Research Institute, Inc., 1994) to solve the regression equations. The output from the tool will include a map of the drainagebasin boundary determined for the site, the values of the GISmeasured basin characteristics, the estimated ground-waterrecharge statistics, and prediction intervals for the estimates.

\section{Summary and Conclusions}

An increase in population and industry in New Hampshire has resulted in an increased demand for water. Determination of ground-water-recharge values will aid Federal, State, local, and private agencies in making water-resource planning, regulatory, and management decisions. To better understand water availability, the U.S. Geological Survey (USGS), in cooperation with the New Hampshire Department of Environmental Services (NHDES), has developed datasets, hydrologic statistical relations, and a geographic information system (GIS) of data coverages for all of New Hampshire. This information provides a basis for water-resources managers for sustainable water-use management.

Table 15. Ranges of basin characteristics used to develop the regression equations for estimating ground-water-recharge rates in New Hampshire drainage basins.

[in., inches; PRISM, Parameter-elevation Regressions on Independent Slopes Model (Daley, 2000); NLCD, National Land Cover Dataset]

\begin{tabular}{lccrc}
\hline \multicolumn{1}{c}{ Basin characteristic } & $\begin{array}{c}\text { Basin } \\
\text { characteristic } \\
\text { abbreviation }\end{array}$ & Minimum & Mean & Maximum \\
\hline Average annual gage precipitation (in.; PRISM) & AGP & 35.83 & 42.93 & 53.11 \\
Average summer gage precipitation (in.; PRISM) & SGP & 16.46 & 18.60 & 23.11 \\
Average spring gage precipitation (in.; PRISM) & SpGP & 6.83 & 8.85 & 11.54 \\
Average annual basin-centroid precipitation (in.; PRISM) & ACP & 37.44 & 45.32 & 75.91 \\
Average mean annual basin temperature (degrees Fahrenheit; PRISM) & ABT & 36.05 & 42.35 & 48.69 \\
& & & & \\
Average minimum winter basin temperature (degrees Fahrenheit; PRISM) & WBT & 0.8 & 10.61 & 19.88 \\
Percent coniferous forest (percent; NLCD) & C & 3.07 & 20.65 & 56.18 \\
Percent mixed coniferous/deciduous forest (percent; NLCD) & CD & 6.21 & 26.05 & 46.13 \\
Average fall basin centroid precipitation (in.; PRISM) & FCP & 6.57 & 8.38 & 15.20 \\
Average annual snowcover (in.; PRISM) & ASC & 54.46 & 102.41 & 219.07 \\
\hline
\end{tabular}


Annual and seasonal ground-water-recharge rates were developed through the analysis of 55 unregulated continuousrecord stream-gaging stations using the Recession-Curve Displacement Computer Program RORA. The seasons, as specified by the NHDES are winter (January 1-March 15), spring (March 16-May 31), summer (June 1-October 31), and fall (November 1-December 31). Stream-gaging stations were not chosen in basins where the streamflow is known to be affected by regulation, diversion, flow augmentation, or hydraulic control structures. A minimum of 10 years of continuous streamflow data was required for a stream-gaging station to be included in the analysis.

Although in many cases streamflow records were considerably longer than 10 years, the length of record for the basinspecific estimation of ground-water recharge determined in this study ranged from 10 to 50 years. The length of the streamgaging station record used to determine the annual and seasonal ground-water-recharge rates was dictated by the length of record of the National Climate Data Center (NCDC) digitalprecipitation database. The digital NCDC precipitation-gage data were available from 1949 through 1998.

A consistent recharge estimate and the statistical significance of the annual and seasonal regression equations relating ground-water recharge and area/distance-weighted NCDC basin-centroid precipitation for each stream-gaging station were determined. Only coefficients significant at the 5-percent level were maintained in the equations. In a few instances, the basin-recharge rate was based only on the Recession-Curve Displacement Computer Program (RORA) (Rutledge, 1998)determined ground-water-recharge rate because the area/distance-weighted NCDC basin-centroid precipitation was not statistically significant.

Temporal variations in recharge were removed by normalizing the ground-water-recharge regression equations to determine the spatial relation of the annual and seasonal groundwater-recharge rates. For consistency among stations that have operated during different periods, annual and seasonal normalized ground-water recharge was determined by substituting the average annual and seasonal basin-centroid values of precipitation for 1961-90, as determined from a 2-kilometer grid Parameter-elevation Regressions on Independent Slopes Model (PRISM), into each of the annual and seasonal basin-recharge equations for the area/distance-weighted NCDC basin-centroid precipitation values.

The regression equations developed in this study relate normalized ground-water-recharge rates at 55 stations to basin and climatic characteristics determined from 93 potential explanatory variables for each basin. The results can be used to estimate ground-water recharge for the unregulated streamgaging station drainage basins used in the regression analysis, as well as for any other unregulated, ungaged basin locations. Ten of the 93 basin characteristics were determined to be the most statistically significant in explaining a significant amount of the variability of the dependent (response) variable. The fol- lowing basin and climatic characteristics were found to be statistically significant predictors for at least one of the dependent variables: average annual, summer, and spring precipitation as determined at U.S. Geological Survey stream-gaging stations; average annual basin-centroid precipitation; average mean annual basin temperature; average minimum winter basin temperature; percent coniferous forest in a basin; percent mixed coniferous and deciduous forest in a basin; average fall basincentroid precipitation; and average annual snowcover. These 10 basin and climatic characteristics were selected because they were statistically significant based on several statistical parameters that evaluated which combination of characteristics contributed the most to the predictive accuracy of the regressionequation models. A geographic information system (GIS) is required to measure the values of the independent variables for the equations developed in the study.

Generalized-least-squares (GLS) regression analysis was used to develop the final equations that determined annual and seasonal ground-water-recharge rates with the computer program generalized-least-squares NETwork (GLSNET). GLS regression analysis accounts for the differences in the variances of the basin-specific recharge estimates, and for the cross-correlation of concurrent flows with other stream-gaging stations. The proportion of variation in the dependent variables (annual and seasonal normalized ground-water recharge) that is explained by the independent variables $\left(R^{2} a d j\right)$ in the groundwater-recharge regression equations ranged from 48 to 67 percent. Average model mean square error (MSE) ranged from 0.3 to 6.4 in.

Generalized estimates of normalized ground-water recharge were derived from GLS regression analysis of selected basin characteristics and RORA-derived recharge values adjusted (normalized) for average precipitation data from 1961 to 1990 (PRISM). A value of 21.0 in. was obtained as the average annual normalized rate of ground-water recharge. The average normalized ground-water recharge for winter was $4.3 \mathrm{in}$., for spring was $9.0 \mathrm{in}$., for summer was $4.0 \mathrm{in}$., and for fall was $3.6 \mathrm{in}$. Annual normalized ground-water recharge ranged from 12.3 to 31.8 in. Normalized ground-water recharge for winter ranged from 2.30 to 7.82 in., for spring ranged from 5.16 to 13.7 in., for summer ranged from 1.45 to 10.2 in., and for fall ranged from 2.21 to $6.06 \mathrm{in}$.

\section{Acknowledgments}

The authors thank Craig Johnston, U.S. Geological Survey, for preparing the numerous GIS data layers that describe the basin and climatic characteristics used in the development of the ground-water-recharge regression equations in this report. Appreciation is extended to Ann Marie Squillacci for the preparation of tables, Anita Cotton for graphics assistance, and Debra Foster for the editorial review of this report (all from the U.S. Geological Survey). 


\section{Selected References}

American Society of Civil Engineers, 1987, Ground-water management (3d ed.): American Society of Civil Engineers Manuals and Reports on Engineering Practice No. 40, 263 p.

Barlow, P.M., and Moench, A.F., 1998, Analytical solutions and computer programs for hydraulic interaction of streamaquifer systems: U.S. Geological Survey Water-Resources Investigations Report 98-415A, 85 p.

Bent, G.C., 1995, Streamflow, ground-water recharge and discharge, and characteristics of surficial deposits in Buzzards Bay Basin, southeastern Massachusetts: U.S. Geological Survey Open-File Report 95-4234, 56 p.

Bent, G.C., 1998, Streamflow, base flow, and ground-water recharge in the Housatonic River Basin, western Massachusetts and parts of eastern New York and northwestern Connecticut: U.S. Geological Survey Water-Resources Investigations Report 98-4232, 68 p.

Billings, M.P., 1956, The geology of New Hampshire, part IIbedrock geology: New Hampshire State Planning and Development Commission, 203 p.

Cavalieri, P., Jayawickrama, J., Luca, R., Patetta, M., Scott, K., and Walsh, S., 2000, Statistics I: Introduction to ANOVA, Regression, and Logistic Regression: Cary, N.C., SAS Institute, Inc., 504 p.

Cohn, T.A., DeLong, L.L., Gilroy, E.J., Hirsch, R.M., and Wells, D.K., 1989, Estimating constituent loads: Water Resources Research, v. 25, no. 5, p. 937-942.

Daly, C., Neilson, R.P., and Phillips, D.L., 1994, A statisticaltopographic model for mapping climatological precipitation over mountainous terrain: Journal of Applied Meterology, v. 33, p. 140-158.

Daly, C., Taylor, G.H., and Gibson, W.P., 1997, The PRISM approach to mapping precipitation and temperature, in reprints, 10th Conference on Applied Climatology, Reno, Nev.: American Meterological Society, p. 10-12.

Daly, C., 2000, PRISM (Parameter-elevation Regressions on Independent Slopes Model): U.S. Department of Agriculture and Natural Resources Conservation Service Climate Mapping Project, National Water and Climate Center, Oregon State University Partnership.

Duan, Naihua, 1983, Smearing estimate: a non-parametric retransformation method: Journal of the American Statistical Association, v. 78, no. 383, p. 605-610.

Dunne, Thomas, and Leopold, L.B., 1978, Water in environmental planning: New York, W.H. Freeman and Company, 818 p.

EarthInfo, Inc., 2000, National Climate Data Center (NCDC) hourly and 15-minute precipitation: Boulder, Colo.

Environmental Systems Research Institute, Inc., 1994, Surface modeling with TIN: Redlands, Calif., 257 p.

Fenneman, N.M., 1938, Physiography of the Eastern United States: New York, McGraw-Hill, 714 p.

Flanagan, S.M., Nielsen, M.G., Robinson, K.W., and Coles, J.F., 1999, Water-quality assessment of the New England coastal basins in Maine, Massachusetts, New Hampshire, and Rhode Island: environmental settings and implications for water quality and aquatic biota: U.S. Geological Survey Water-Resources Investigations Report 98-4249, 62 p.

Flynn, K.M., Hummel, P.R., Lumb, A.M., and Kittle, J.L., Jr., 1995, User's manual for ANNIE, version 2, a computer program for interactive hydrologic data management: U.S. Geological Survey Water-Resources Investigations Report 954085, $211 \mathrm{p}$.

Flynn, R.H., 2002, Development of regression equations to estimate flow durations and low-flow-frequency statistics in New Hampshire streams: U.S. Geological Survey WaterResources Investigations Report 02-4298, 86 p.

Flynn, R.H., 2003, A stream-gaging network analysis for the annual 7-day, 10-year low flow in New Hampshire streams: U.S. Geological Survey Water-Resources Investigations Report 03-4023, 41 p., accessed March 30, 2004, at http://pubs.water.usgs.gov/wrir03-4023

Freund, R.J., and Littell, R.C., 2000, SAS system for regression (3d ed.): Cary, N.C., 235 p.

Gilroy, E.J., Hirsch, R.M., and Cohn, T.A., 1990, Mean square error of regression-based constituent transport estimates: Water Resources Research, v. 26, no. 9, p. 2,069-2,077.

Hammond, R.E., and Cotton, J.E., 1986, National Water Summary 1985-New Hampshire surface-water resources: U.S. Geological Survey Water-Supply Paper 2300, p. 329-334.

Hammond, R.E., 1989, National Water Summary, 198889-New Hampshire hydrologic events and floods and droughts: U.S. Geological Survey Water-Supply Paper 2375, p. 393-399.

Harvey, C.A., and Eash, D.A., 1995, Description, instructions, and verification for Basinsoft, a computer program to quantify drainage-basin characteristics: U.S. Geological Survey Water-Resources Investigations Report 95-4287, 25 p.

Hayes, D.C., 1991, Low-flow characteristics of streams in Virginia: U.S. Geological Survey Water-Supply Paper 2374, $69 \mathrm{p}$.

Helsel, D.R., and Hirsch, R.M., 2000, Statistical methods in water resources, 4th Impression: Amsterdam, the Netherlands, Elsevier Science B.V. Studies in Environmental Science 49, $529 \mathrm{p}$.

Hershfield, D.M., 1961, Rainfall frequency atlas of the United States for durations from 30 minutes to 24 hours and return periods from 1 to 100 years: U.S. Department of Commerce Technical Paper 40, 61 p.

Holtschlag, D.J., 1997, A generalized estimate of groundwater-recharge rates in the lower peninsula of Michigan: U.S. Geological Survey Water-Supply Paper 2437, 37 p.

Hoos, A.B., 1990, Recharge rates and aquifer hydraulic characteristics for selected drainage basins in middle and east Tennessee: U.S. Geological Survey Water-Resources Investigations Report 90-4015, 34 p.

Knott, J.F., and Olimpio, J.C., 1986, Estimation of recharge rates to the sand and gravel aquifer using environmental tritium, Nantucket Island, Massachusetts: U.S. Geological Survey Water-Supply Paper 2297, 26 p. 
Lam, Longhow, 1999, An introduction to S-Plus for windows: Amsterdam, The Netherlands, CANdiensten, $164 \mathrm{p}$.

Lumb, A.M., Kittle, J.L., Jr., and Flynn, K.M., 1990, User's manual for ANNIE, a computer program for interactive hydrologic analyses and data management: U.S. Geological Survey Water-Resources Investigations Report 89-4080, $236 \mathrm{p}$.

Lyford, F.P., and Cohen, A.J., 1988, Estimation of water available for recharge to sand and gravel aquifers in the glaciated Northeastern United States: American Water Resources Association, Monograph Series no. 11, p. 37-61.

MacNish, R.D., and Randall, A.D., 1982, Stratified-drift aquifers in the Susquehanna River basin, New York: New York State Department of Environmental Conservation Bulletin $75,68 \mathrm{p}$.

MathSoft, Inc., 1999, S-Plus 2000 modern statistics and advanced graphics: Cambridge, Mass., 558 p.

Mazzaferro, D.L., Handman, E.H., and Thomas, M.P., 1979, Water resources inventory of Connecticut, Part 8, Quinnipiac River basin: Connecticut Water Resources Bulletin, no. 27,88 p.

McCuen, R.H., Johnson, P.A., and Ragan, R.M., 1996, HDS 2 (Hydraulic Design Series No. 2): Federal Highway Administration, Highway Hydrology, Report no. FHWA SA-96067, $375 \mathrm{p}$.

Medalie, Laura, and Moore, R.B., 1995, Ground-water resources in New Hampshire: stratified-drift aquifers: U.S. Geological Survey Water-Resources Investigations Report 95-4100, 31 p.

Meinzer, O.E., and Stearns, N.D., 1929, A study of ground water in the Pomeraug Basin, Connecticut: U.S. Geological Survey Water-Supply Paper 597-B, 146 p.

Melvin, R.L., deLima, Virginia, and Stone, B.D., 1992, The stratigraphy and hydraulic conductivity properties of tills in southern New England: U.S. Geological Survey Open-File Report 91-481, 53 p.

Morgan, D.S., and Jones, J.L., 1995, Numerical model analysis of the effects of ground-water withdrawals on discharge to streams and springs in small basins typical of the Puget Sound lowland, Washington: U.S. Geological Survey OpenFile Report 95-470, 79 p.

Morrissey, D.J., 1983, Hydrology of the Little Androscoggin River valley aquifer, Oxford County, Maine: U.S. Geological Survey Water-Resources Investigations 83-4018, 79 p.

Morrissey, D.J., Randall, A.D., and Williams, J.H., 1988, Upland runoff as a major source of recharge to stratified drift in the glaciated Northeast: American Water-Resources Association Monograph Series no. 11, p. 17-36.

Moss, M.E., and Tasker, G.D., 1991, An intercomparison of hydrological network-design technologies: Hydrological Sciences Journal, 36(3), p. 209-221.

New Hampshire Department of Environmental Services, 2001, The Source: Concord, N.H., Summer 2001, 4 p.

New Hampshire Division of Forests and Lands, 1997, New Hampshire forest statistics, accessed April 11, 2002, at http://www.nhdfl.org/info_plan_bureau/

fi\&p_foreststatistics.htm
New Hampshire State Data Center, 2001, New Hampshire census information, accessed July 26, 2001 and April 11, 2002, at http://www.state.nh.us/osp/sdc/sdc.html

Ries, K.G., 1994a, Estimation of low-flow-duration discharges in Massachusetts: U.S. Geological Water-Supply Paper 2418, 50 p.

Ries, K.G., 1994b, Development and application of generalized-least-squares regression models to estimate low-flowduration discharges in Massachusetts: U.S. Geological Survey Water-Resources Investigations Report 94-4155, $33 \mathrm{p}$.

Ries, K.G., and Friesz P.J., 2000, Methods for estimating lowflow statistics for Massachusetts streams: U.S. Geological Survey Water-Resources Investigations Report 00-4135, $81 \mathrm{p}$.

Rorabaugh, M.I., 1964, Estimating changes in bank storage and ground-water contribution to streamflow: International Association of Scientific Hydrology, Publication 63, p. 432441.

Rutledge, A.T., 1993, Computer programs for describing the recession of ground-water discharge and for estimating the mean ground-water recharge and discharge from streamflow records: U.S. Geological Survey Water-Resources Investigations Report 93-4121, 45 p.

Rutledge, A.T., 1997, Model-estimated ground-water recharge and hydrograph of ground-water discharge to a stream: U.S. Geological Survey Water-Resources Investigations Report 97-4253, $29 \mathrm{p}$.

Rutledge, A.T., 1998, Computer programs for describing the recession of ground-water discharge and for estimating mean ground-water recharge and discharge from streamflow dataupdate: U.S. Geological Survey Water-Resources Investigations Report 98-4148, 43 p.

Rutledge, A.T., 2000, Considerations for use of the RORA program to estimate ground-water recharge from streamflow records: U.S. Geological Survey Open-File Report 00-156, $44 \mathrm{p}$.

Rutledge, A.T., and Mesko, T.O., 1996, Estimated hydrologic characteristics of shallow aquifer systems in the Valley and Ridge, the Blue Ridge, and the Piedmont Physiographic Provinces based on analysis of streamflow recession and base flow: U.S. Geological Survey Professional Paper $1422-\mathrm{B}, 58 \mathrm{p}$.

SAS Institute Inc., 1994, SAS/STAT User's Guide, version 6, (4th ed.), v. 2: Cary, N.C., 1,686 p.

Savard, C.S., 1998, Estimated ground-water recharge from streamflow in Fortymile Wash near Yucca Mountain, Nevada: U.S. Geological Survey Water-Resources Investigations Report 97-4273, 30 p.

Schwarz, G.E., and Alexander, R.B., 1995, STATE Soil GeOgraphic (STATSGO) database for the conterminous United States: U.S. Geological Survey Open-File Report 95-449, $95 \mathrm{p}$.

Simmers, I., Ed., 1988, Estimation of natural ground-water recharge: Norwell, Mass., D. Reidel Publishing, NATO Advanced Science Institute Series C, Mathematical and Physical Sciences, v. 222, 510 p. 
Stedinger, J.R., and Tasker, G.D., 1985, Regional hydrologic analysis 1 . Ordinary, weighted, and generalized-leastsquares compared: Water Resources Research, v. 21, no. 9, p. $1,421-1,432$.

Stedinger, J.R., and Tasker, G.D., 1986, Regional hydrologic analysis 2: Water Resources Research, v. 22, no. 10, p. 1,487-1,499.

Swain, L.A., Hollyday, E.F., Daniel, C.C., III, and Zapecza, O.S., 1991, Plan of study for the regional aquifersystem analysis of the Applachian Valley and Ridge, Piedmont, and Blue Ridge physiographic provinces of the eastern and southeastern United States, with a description of studyarea geology and hydrology: U.S. Geological Survey WaterResources Investigations Report 91-4066, 44 p.

Tasker, G.D., and Stedinger, J.R., 1989, An operational GLS model for hydrologic regression: Journal of Hydrology, v. 3, p. 361-375.

Thornthwaite, C.W., and Mather, J.R., 1957, Instructions and tables for computing potential evapotranspiration and the water balance, Publications in climatology: Drexel Institute of Technology, v. 10, no. 3, p. 185-311.

U.S. Department of Agriculture, Natural Resources Conservation Service, National Soil Survey Center, 1991, State Soil Geographic (STATSGO) Data Base: Data use information: Miscellaneous Publication No. 1492, 110 p. (revised July 1994).

U.S. Department of Commerce Weather Bureau, 1961, Rainfall frequency atlas of the United States for durations from
30 minutes to 24 hours and return periods from 1 to 100 years: Technical Paper 40, 61 p.

U.S. Geological Survey, 1990, National Water Summary 1987-New Hampshire water supply and use: U.S. Geological Survey Water-Supply Paper 2350, p. 361-366.

U.S. Geological Survey, 1997, STATSGO soil characteristics for the conterminous United States: U.S. Geological Survey Open-File Report 656, accessed July 26, 2001, at http://water.usgs.gov/GIS/metadata/usgswrd/muid.html U.S. Geological Survey, 2000, National Land Cover Dataset: U.S. Geological Survey Fact Sheet 108-00, accessed August 28, 2001, at http://mac.usgs.gov/mac/isb/pubs/factsheets/ fs $10800 . h t m l$

Vecchioli, John, Tibbals, C.H., Duerr, A.D., Hutchinson, C.B., 1990, Ground-water recharge in Florida-a pilot study in Okaloosa, Pasco, and Volusia Counties: U.S. Geological Survey Water-Resources Investigations Report 90-4195, 16 p.

Vogelmann, J.E., Howard, S.M., Yang, L., Larson, C.R., Wylie, B.K., Van Driel, N., 2001, Completion of the 1990s National land cover dataset for the conterminous United States: LANDSAT Thematic Mapper Data and ancillary data sources, Photogrammetric Engineering and Remote Sensing, v. 67, p. 650-652.

Wandle, S.W., Jr., and Randall, A.D., 1994, Effects of surficial geology, lakes and swamps, and annual water availability on low-flows of streams in central New England, and their use in low-flow estimation: U.S. Geological Survey WaterResources Investigations Report 93-4092, 57 p. 


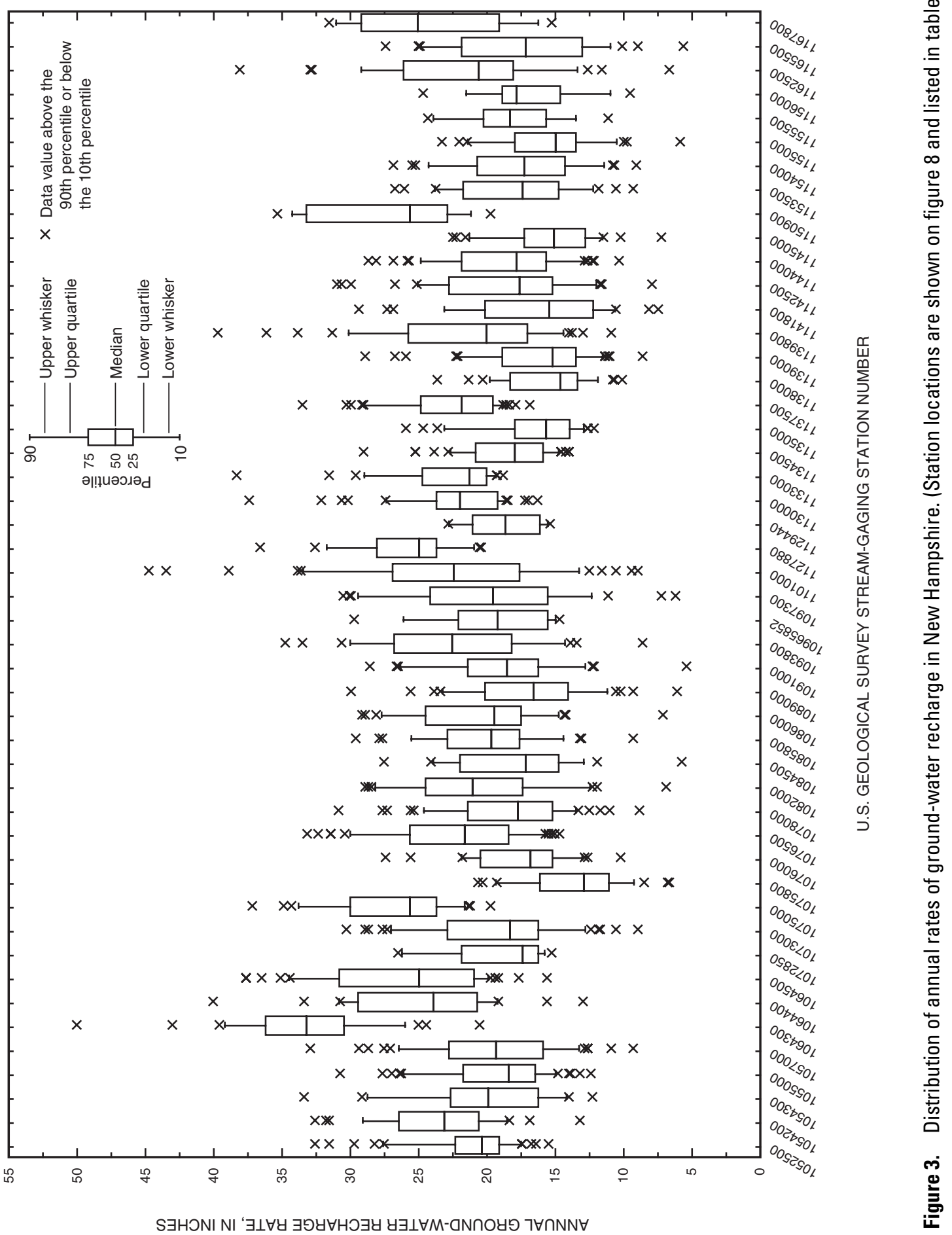




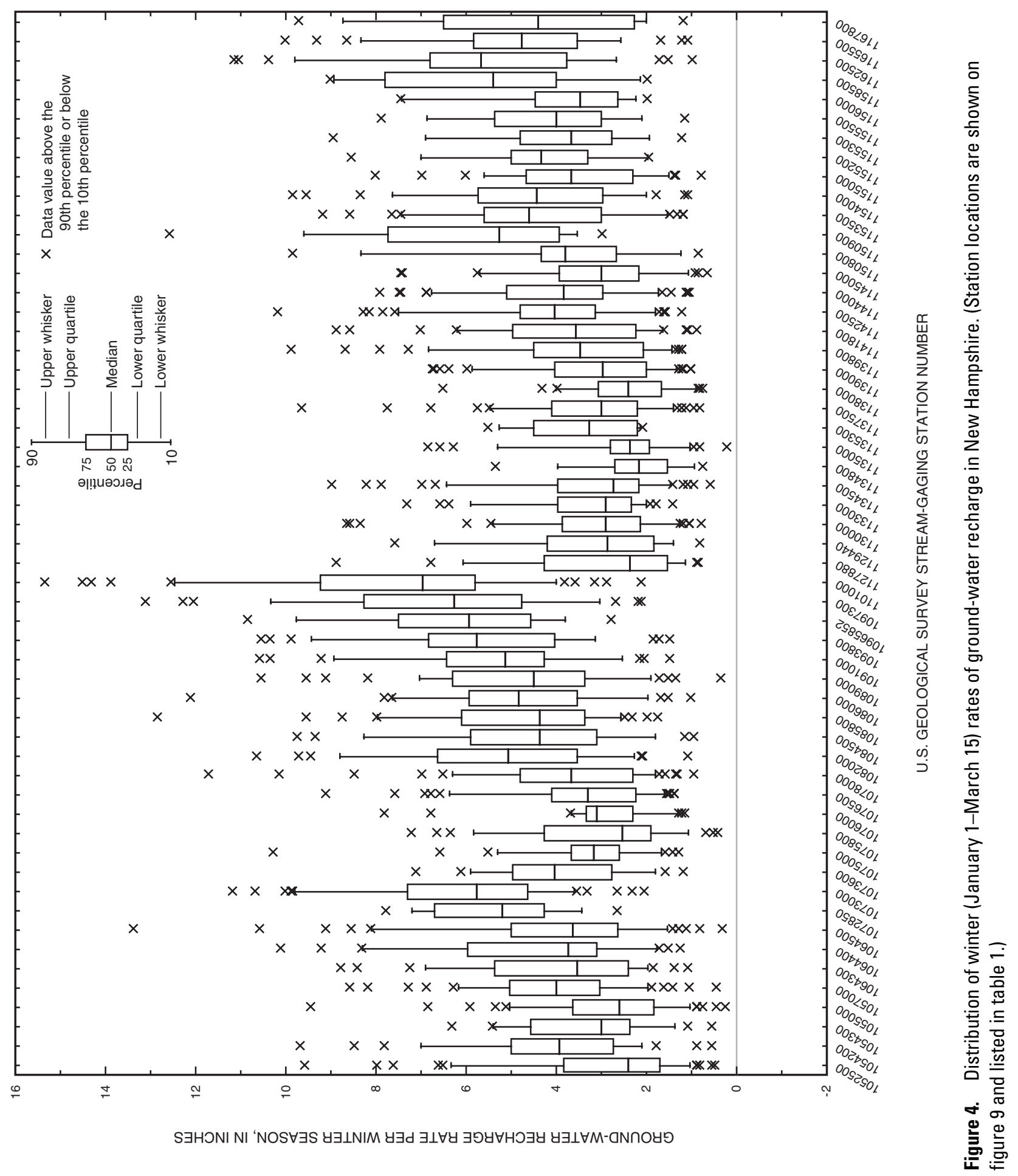




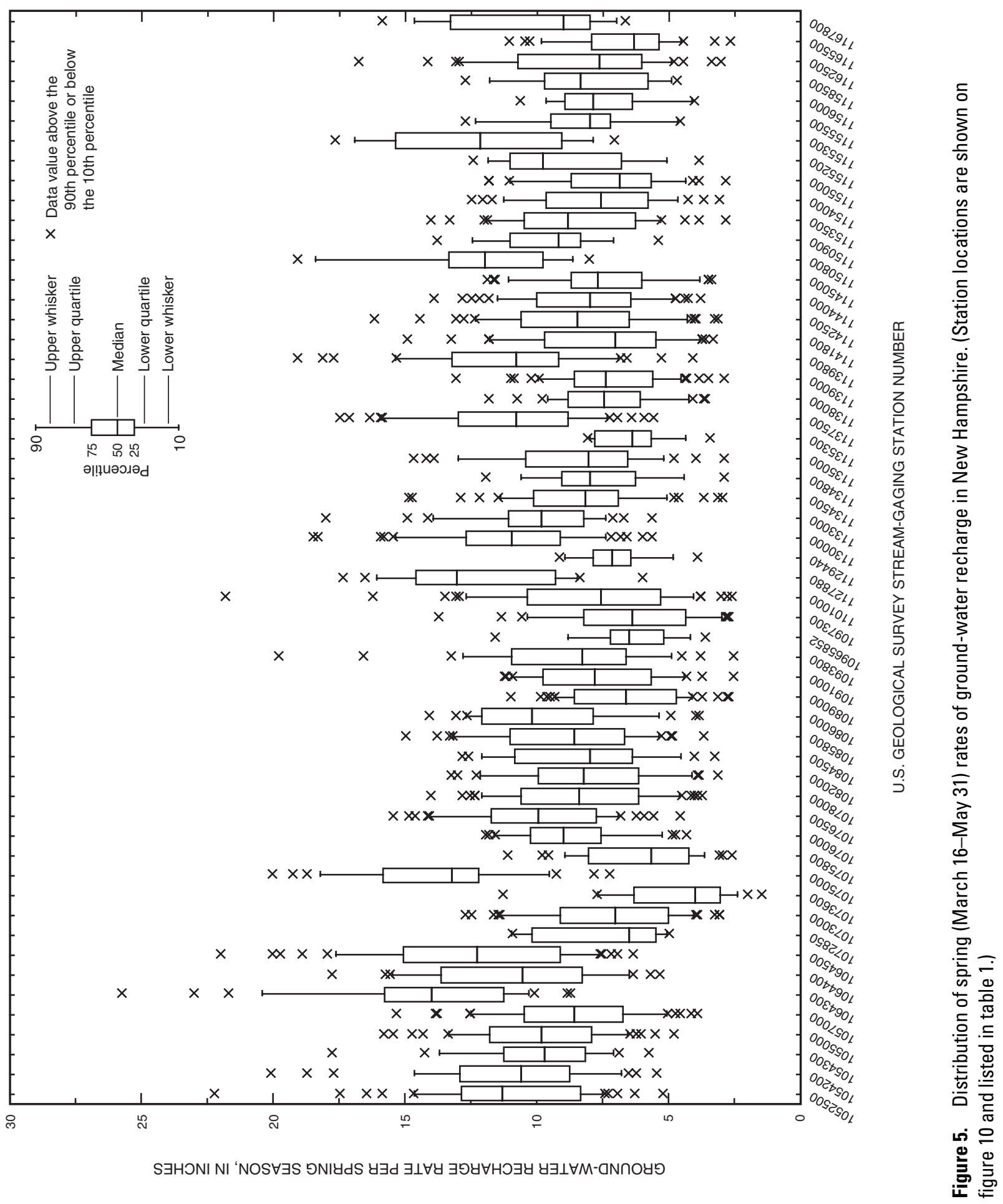




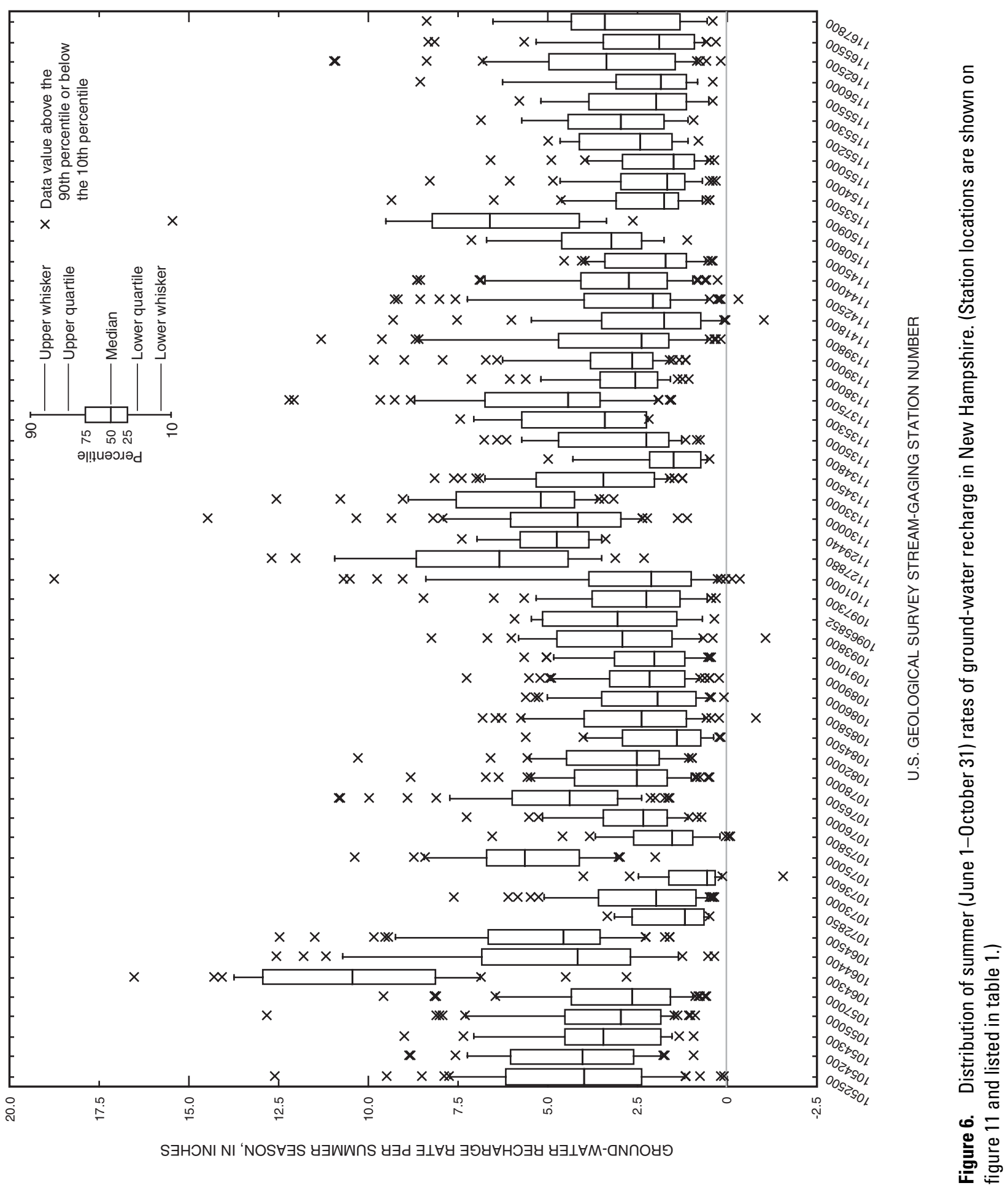




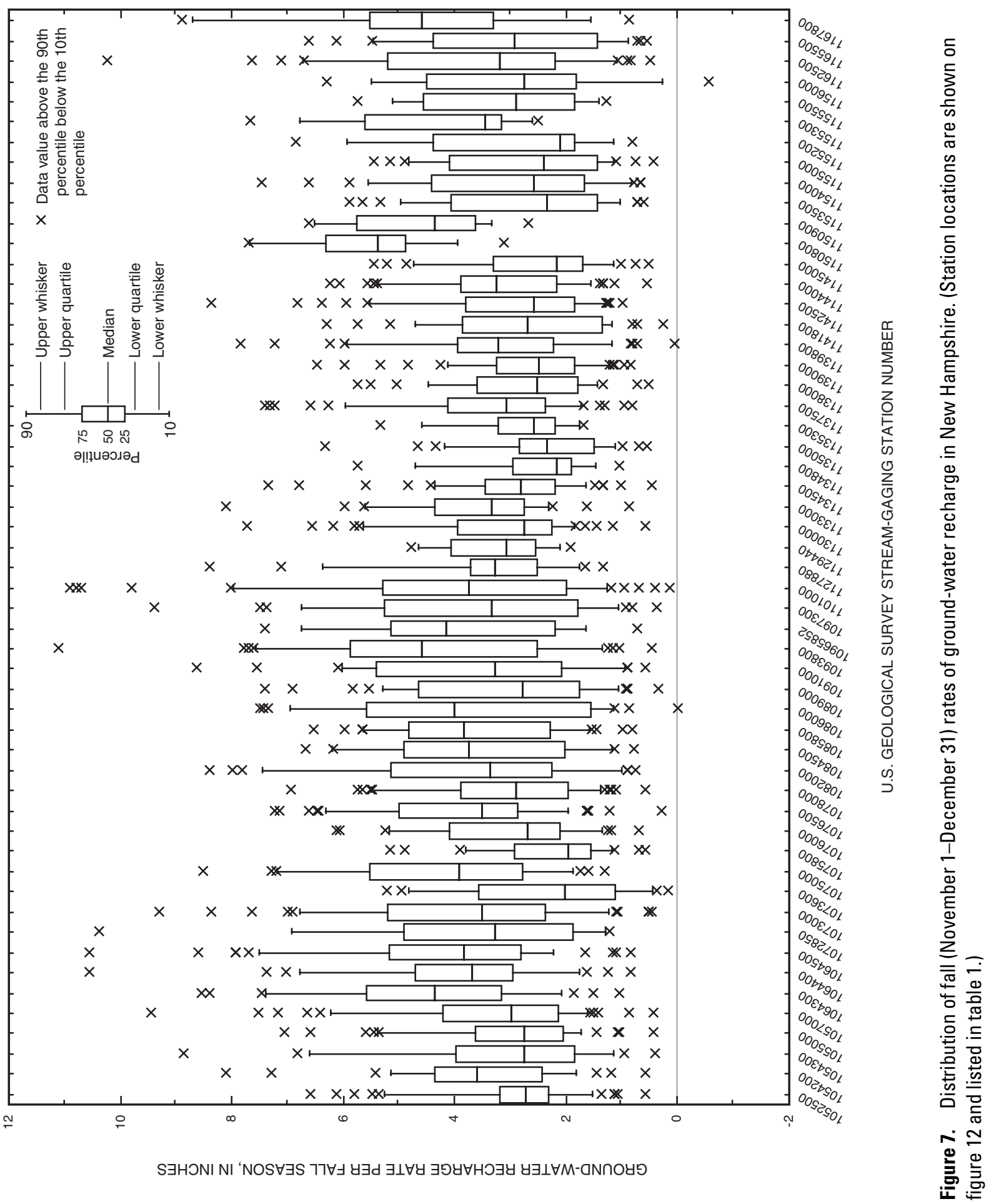




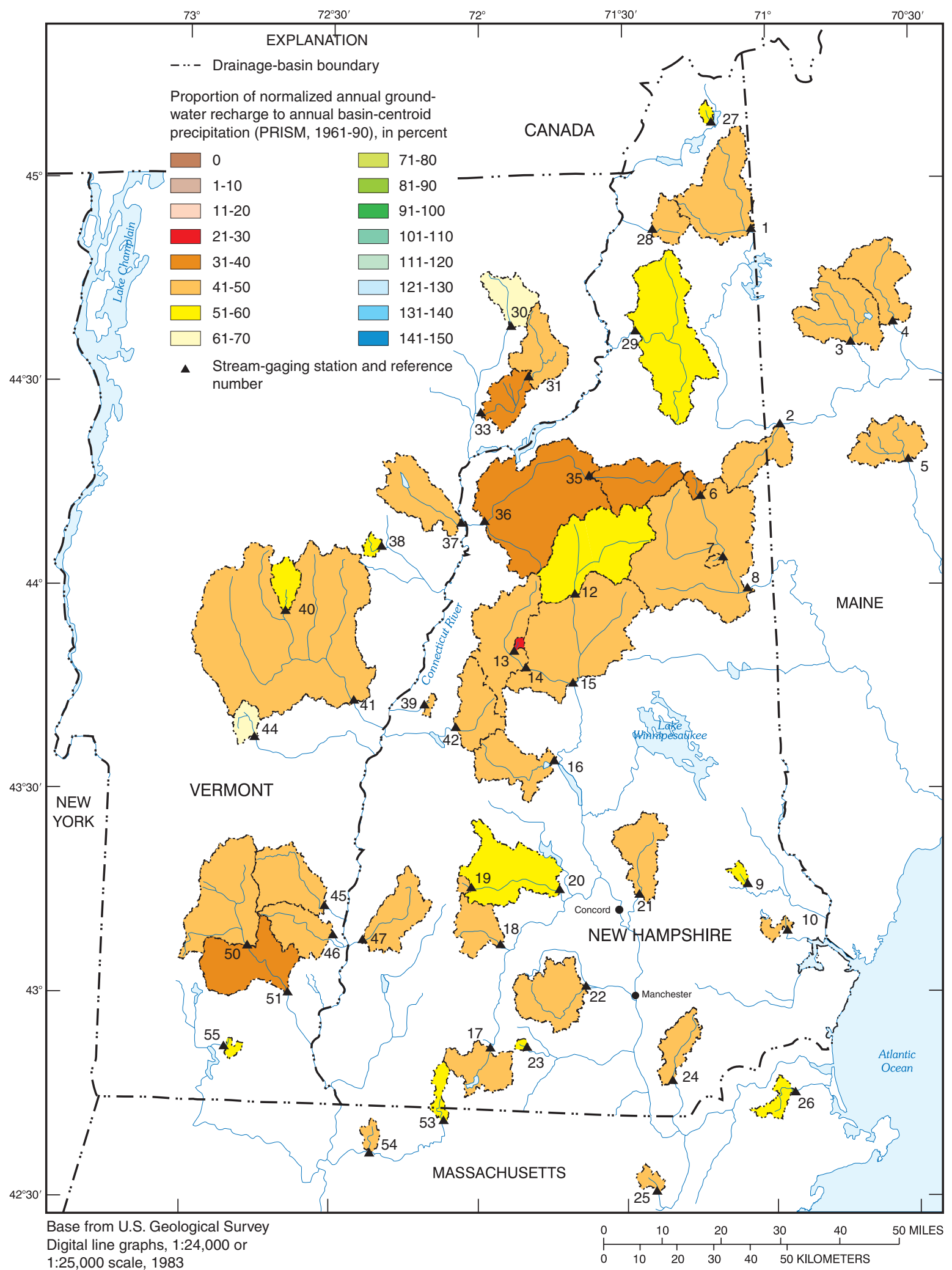

Figure 8. Drainage basins that were used to develop the equations for estimating annual (January 1-December 31) ground-water-recharge statistics in New Hampshire showing the proportion (in percent) of normalized annual groundwater recharge to annual basin-centroid precipitation. (Station reference numbers are listed in table 1.) 


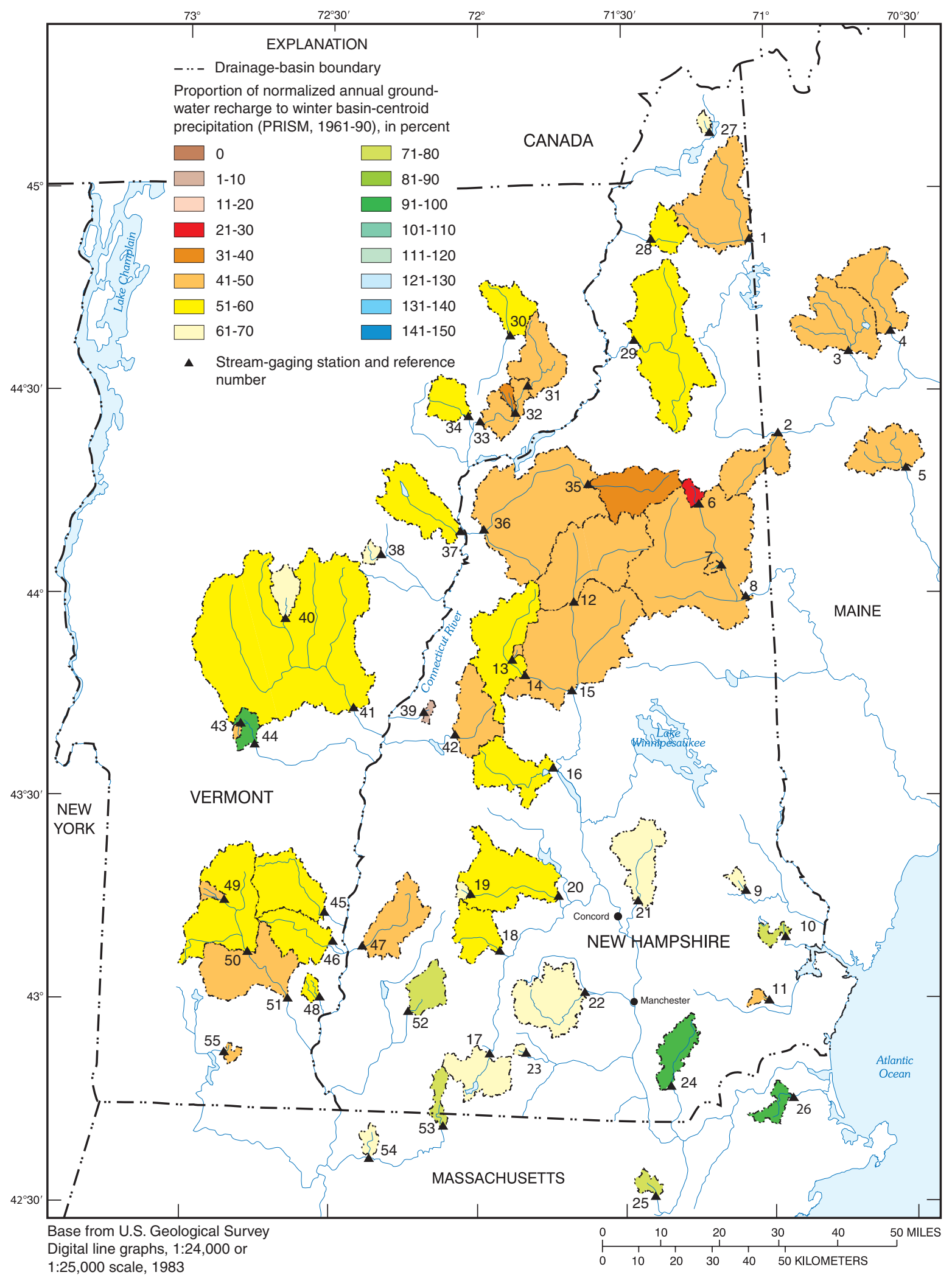

Figure 9. Drainage basins that were used to develop the equations for estimating winter (January 1-March 15) ground-water-recharge statistics in New Hampshire showing the proportion (in percent) of normalized winter groundwater recharge to winter basin-centroid precipitation. (Station reference numbers are listed in table 1.) 


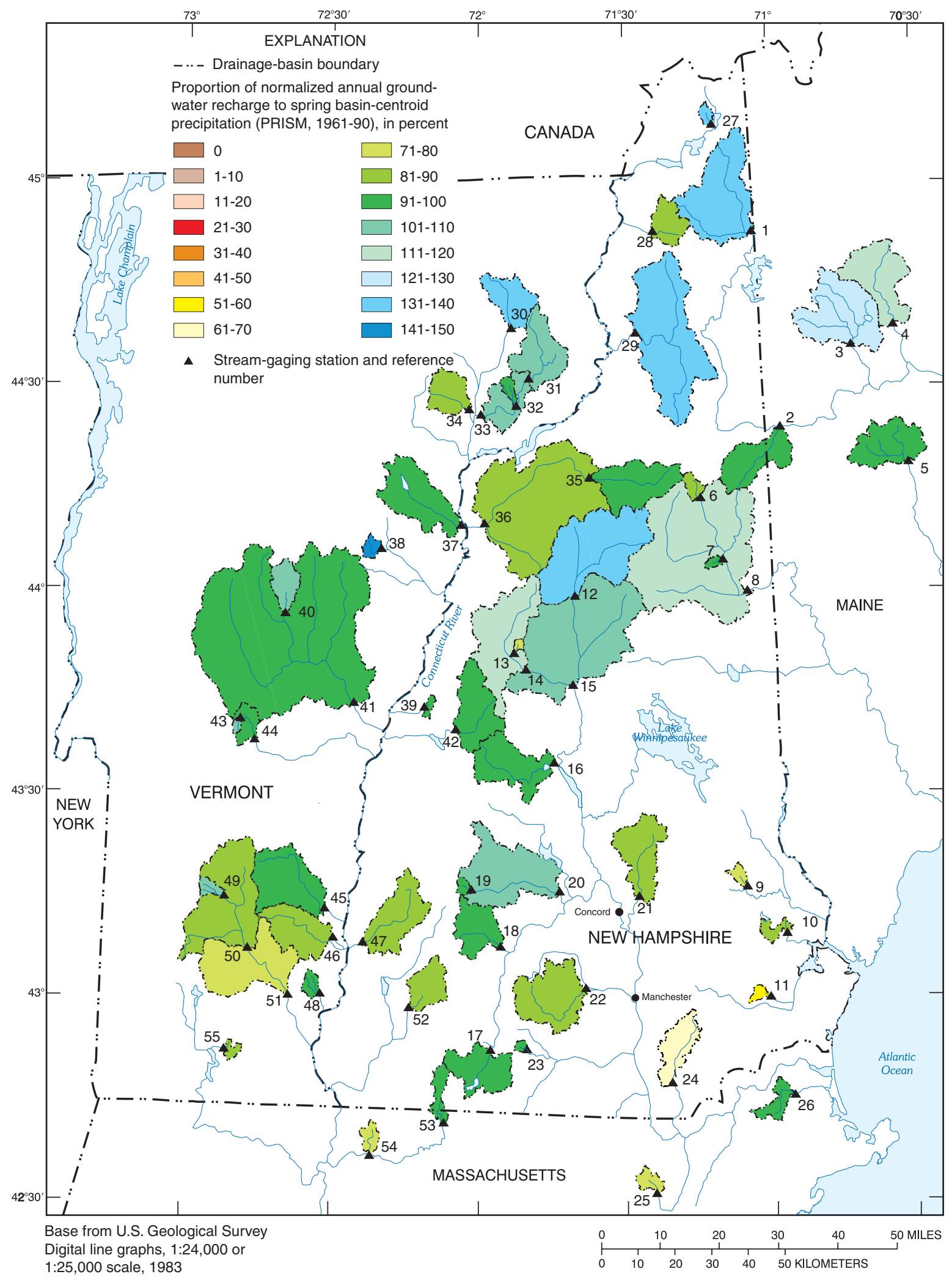

Figure 10. Drainage basins that were used to develop the equations for estimating spring (March 16-May 31) groundwater-recharge statistics in New Hampshire showing the proportion (in percent) of normalized spring ground-water recharge to spring basin-centroid precipitation. (Station reference numbers are listed in table 1.) 


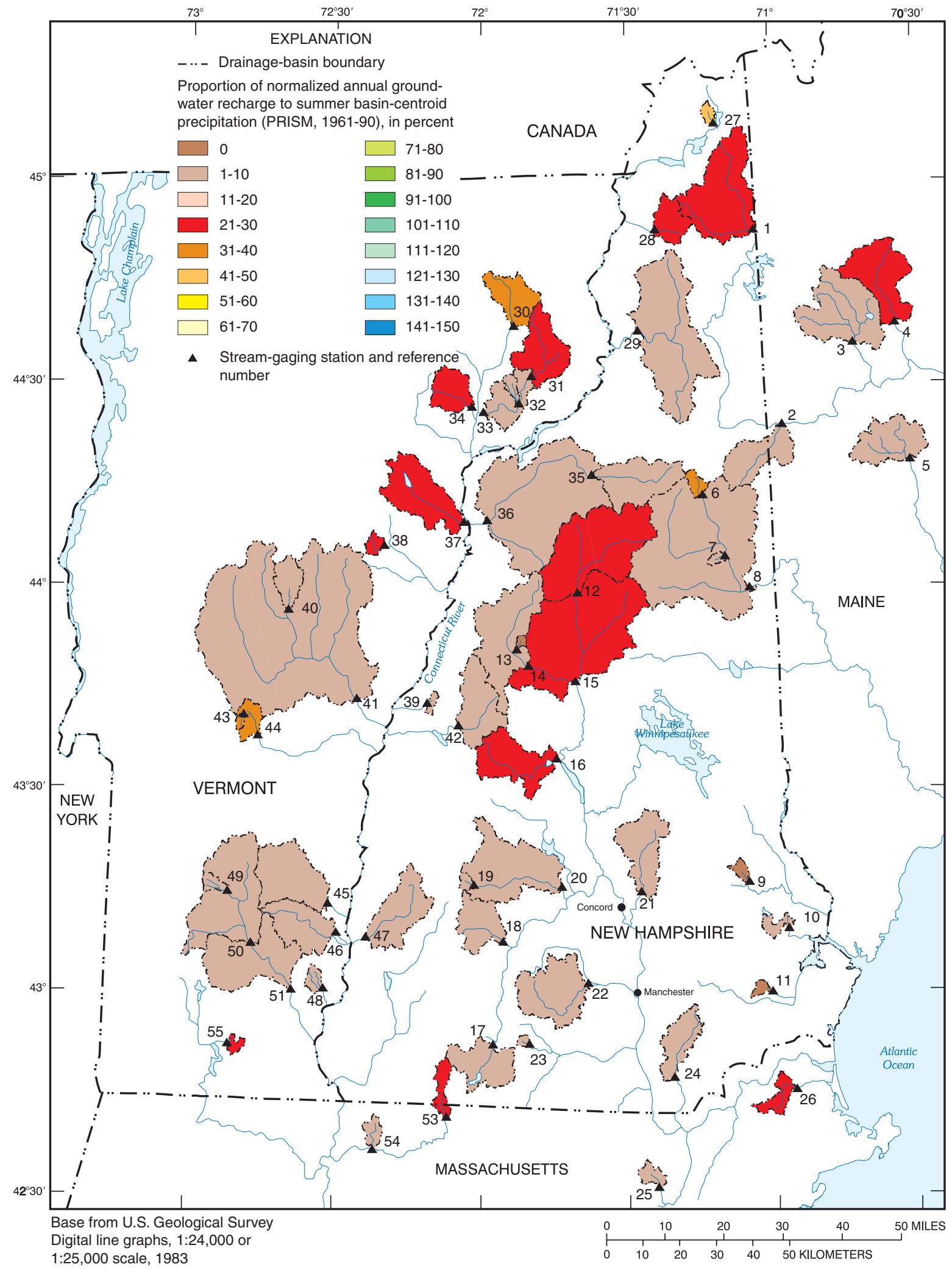

Figure 11. Drainage basins that were used to develop the equations for estimating summer (June 1-0ctober 31) ground-water-recharge statistics in New Hampshire showing the proportion (in percent) of normalized summer ground-water recharge to summer basin-centroid precipitation. (Station reference numbers are listed in table 1.) 


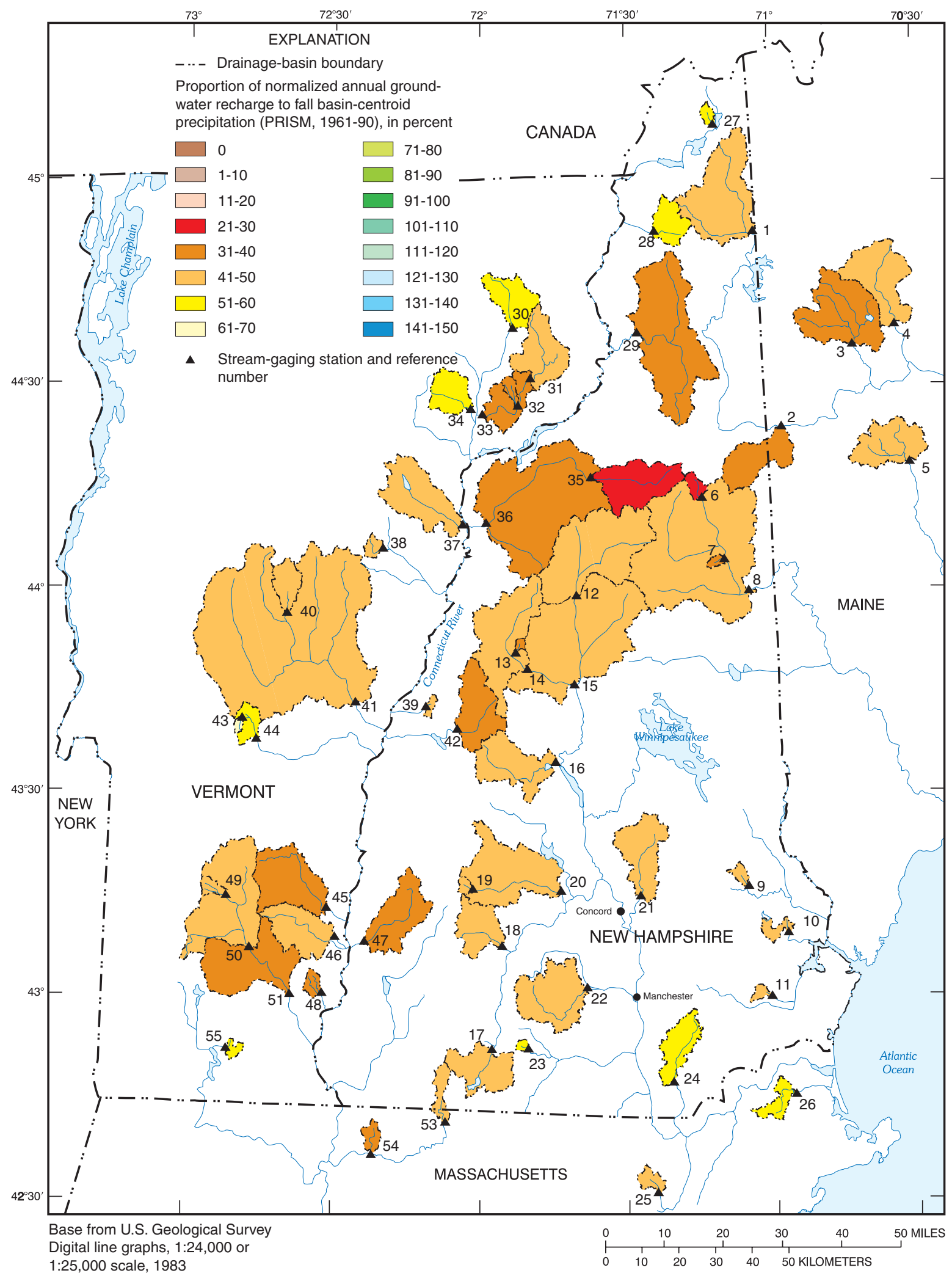

Figure 12. Drainage basins that were used to develop the equations for estimating fall (November 1-December 31) ground-water-recharge statistics in New Hampshire showing the proportion (in percent) of normalized fall ground-water recharge to fall basin-centroid precipitation. (Station reference numbers are listed in table 1.) 
Table 3. Annual (January 1-December 31) normalized basin-recharge rates determined from basin-specific regression equations relating Rorabaugh-method-determined ground-water-recharge rates and basin-centroid precipitation.

[No., number; Location of stream-gaging stations are shown in figure 1 and reference numbers and descriptions of stream-gaging stations are listed in table 1 ; RORA, Recession-curve-displacement computer program; in., inch; yr, year; $B_{0}, B_{1}, R^{2}$, regression model coefficients; MSE, Mean Square Error]

\begin{tabular}{|c|c|c|c|c|c|c|c|c|c|c|}
\hline $\begin{array}{c}\text { Stream- } \\
\text { gaging } \\
\text { station } \\
\text { No. }\end{array}$ & River & Location & $\begin{array}{c}\text { Average } \\
\text { drainage- } \\
\text { basin } \\
\text { (RORA) } \\
\text { recharge } \\
\text { rate } \\
\text { (in/yr) }\end{array}$ & $\begin{array}{l}\text { Normal- } \\
\text { ized } \\
\text { drainage- } \\
\text { basin } \\
\text { recharge } \\
\text { rate } \\
\text { (in/yr) }\end{array}$ & $\boldsymbol{B}_{0}$ & $\boldsymbol{B}_{1}$ & $\begin{array}{c}\text { Nor- } \\
\text { malized } \\
\text { drainage- } \\
\text { basin- } \\
\text { centroid } \\
\text { precipi- } \\
\text { tation } \\
\text { (in/yr) }\end{array}$ & $\begin{array}{c}\text { Coefficient } \\
\text { of deter- } \\
\text { mination } \\
\left(R^{2}\right)\end{array}$ & $\begin{array}{l}\text { Root } \\
\text { MSE } \\
\text { (in.) }\end{array}$ & $\begin{array}{l}\text { Years } \\
\text { of } \\
\text { record }\end{array}$ \\
\hline 1052500 & Diamond River & Wentworth Location, N.H. & 21.37 & 23.10 & 12.65 & 0.2172 & 48.11 & 0.1668 & 3.499 & 50 \\
\hline 1054200 & Wild River & Gilead, Maine & 23.06 & 20.71 & 15.27 & .1095 & 49.69 & .1616 & 4.18 & 33 \\
\hline 1054300 & Ellis River & South Andover, Maine & 20.35 & 18.24 & -9.971 & .7217 & 39.09 & .5849 & 3.715 & 17 \\
\hline 1055000 & Swift River & Near Roxbury, Maine & 19.51 & 19.64 & 9.367 & .2357 & 43.58 & .3103 & 3.554 & 50 \\
\hline 1057000 & $\begin{array}{l}\text { Little Androscog- } \\
\text { gin River }\end{array}$ & Near South Paris, Maine & 19.42 & 18.28 & 9.418 & .2027 & 43.70 & .2655 & 4.355 & 50 \\
\hline 1064300 & Ellis River & Near Jackson, N.H. & 33.17 & 29.96 & 16.15 & .182 & 75.91 & .2821 & 4.853 & 34 \\
\hline 1064400 & Lucy Brook & Near North Conway, N.H. & 24.42 & 24.88 & 22.84 & .0285 & 54.57 & .0049 & 6.149 & 26 \\
\hline 1064500 & Saco River & Near Conway, N.H. & 26.00 & 23.99 & 17.94 & .1204 & 50.16 & .1141 & 5.451 & 50 \\
\hline 1072850 & Mohawk River & Center Strafford, N.H. & 18.73 & 23.89 & -14.66 & .818 & 47.13 & .6531 & 2.47 & 11 \\
\hline 1073000 & Oyster River & Durham, N.H. & 19.46 & 20.66 & -8.654 & .6789 & 43.19 & .8078 & 2.243 & 50 \\
\hline 1075000 & $\begin{array}{l}\text { Pemigewasset } \\
\text { River }\end{array}$ & Woodstock, N.H. & 26.90 & 26.23 & 12.86 & .2652 & 50.43 & .3257 & 3.821 & 28 \\
\hline 1075800 & Stevens Brook & Wentworth, N.H. & 13.27 & 12.34 & 0.7134 & .2831 & 41.06 & .2896 & 3.088 & 33 \\
\hline 1076000 & Baker River & Rumney, N.H. & 17.54 & 16.96 & -2.641 & .5234 & 37.44 & .759 & 1.973 & 27 \\
\hline 1076500 & $\begin{array}{l}\text { Pemigewasset } \\
\text { River }\end{array}$ & Plymouth, N.H. & 22.13 & 22.14 & 11.671 & .2152 & 48.62 & .1612 & 4.6 & 50 \\
\hline 1078000 & Smith River & Near Bristol, N.H. & 18.45 & 20.97 & -5.941 & .6076 & 44.29 & .6914 & 2.592 & 50 \\
\hline 1082000 & Contoocook River & Peterborough, N.H. & 20.20 & 21.25 & -9.683 & 6997 & 44.21 & .7086 & 3.16 & 28 \\
\hline 1084500 & Beards Brook & Hillsboro, N.H. & 18.08 & 22.93 & -6.692 & .6361 & 46.57 & .8099 & 2.225 & 21 \\
\hline 1085800 & $\begin{array}{l}\text { West Branch } \\
\text { Warner River }\end{array}$ & Near Bradford, N.H. & 20.11 & 22.69 & -2.749 & .5618 & 45.28 & .7134 & 2.487 & 35 \\
\hline 1086000 & Warner River & Davisville, N.H. & 20.52 & 24.02 & -7.083 & .6967 & 44.65 & .8934 & 1.726 & 29 \\
\hline 1089000 & Soucook River & Near Concord, N.H. & 17.06 & 16.37 & -9.728 & .6758 & 38.62 & .8191 & 2.015 & 44 \\
\hline 1091000 & $\begin{array}{l}\text { South Branch } \\
\text { Piscataquog River }\end{array}$ & Near Goffstown, N.H. & 18.88 & 19.98 & -7.581 & .6347 & 43.43 & .7031 & 2.814 & 29 \\
\hline 1093800 & $\begin{array}{l}\text { Stony Brook } \\
\text { Tributary }\end{array}$ & Near Temple, N.H. & 22.15 & 25.09 & -8.24 & .6882 & 48.43 & .6017 & 3.932 & 34 \\
\hline 1097300 & Nashoba Brook & Near Acton, Mass. & 19.51 & 20.05 & -8.98 & .6572 & 44.17 & .5234 & 4.443 & 34 \\
\hline 1101000 & Parker River & Byfield, Mass. & 23.10 & 26.10 & -20.65 & 1.04 & 44.96 & .7763 & 3.837 & 50 \\
\hline 1127880 & Big Brook & Pittsburg, N.H. & 25.76 & 28.85 & 15.32 & .276 & 49.02 & .2393 & 3.584 & 20 \\
\hline 1129440 & Mohawk River & Near Colebrook, N.H. & 18.53 & 19.17 & 6.951 & .2688 & 45.43 & .5695 & 1.875 & 11 \\
\hline 1130000 & $\begin{array}{l}\text { Upper Ammo- } \\
\text { noosuc River }\end{array}$ & Near Groveton, N.H. & 22.34 & 20.66 & 15.82 & .1213 & 39.92 & .1042 & 4.026 & 48 \\
\hline
\end{tabular}


Table 3. Annual (January 1-December 31) normalized basin-recharge rates determined from basin-specific regression equations relating Rorabaugh-method-determined ground-water-recharge rates and basin-centroid precipitation.-Continued

[No., number; Location of stream-gaging stations are shown in figure 1 and reference numbers and descriptions of stream-gaging stations are listed in table 1; RORA, Recession-curve-displacement computer program; in., inch; yr, year; $B_{0}, B_{1}, R^{2}$, regression model coefficients; MSE, Mean Square Error]

\begin{tabular}{|c|c|c|c|c|c|c|c|c|c|c|}
\hline $\begin{array}{c}\text { Stream- } \\
\text { gaging } \\
\text { station } \\
\text { No. }\end{array}$ & River & Location & $\begin{array}{c}\text { Average } \\
\text { drainage- } \\
\text { basin } \\
\text { (RORA) } \\
\text { recharge } \\
\text { rate } \\
\text { (in/yr) }\end{array}$ & $\begin{array}{l}\text { Normal- } \\
\text { ized } \\
\text { drainage- } \\
\text { basin } \\
\text { recharge } \\
\text { rate } \\
\text { (in/yr) }\end{array}$ & $\boldsymbol{B}_{0}$ & $\boldsymbol{B}_{1}$ & $\begin{array}{c}\text { Nor- } \\
\text { malized } \\
\text { drainage- } \\
\text { basin- } \\
\text { centroid } \\
\text { precipi- } \\
\text { tation } \\
\text { (in/yr) }\end{array}$ & $\begin{array}{c}\text { Coefficient } \\
\text { of deter- } \\
\text { mination } \\
\left(R^{2}\right)\end{array}$ & $\begin{array}{c}\text { Root } \\
\text { MSE } \\
\text { (in.) }\end{array}$ & $\begin{array}{l}\text { Years } \\
\text { of } \\
\text { record }\end{array}$ \\
\hline 1133000 & $\begin{array}{l}\text { East Branch } \\
\text { Passumpsic }\end{array}$ & East Haven, Vt. & 23.01 & 27.11 & -6.629 & 0.7956 & 42.40 & 0.6723 & 2.615 & 29 \\
\hline 1134500 & Moose River & Victory, Vt. & 18.51 & 18.63 & 11.11 & .1679 & 44.80 & .2194 & 3.018 & 50 \\
\hline 1135000 & Moose River & St. Johnsbury, Vt. & 16.48 & 16.70 & 3.518 & .3147 & 41.89 & .4299 & 2.691 & 34 \\
\hline 1137500 & $\begin{array}{l}\text { Ammonoosuc } \\
\text { River }\end{array}$ & Bethlehem Junction, N.H. & 22.95 & 20.61 & 13.99 & .1175 & 56.38 & .2272 & 3.367 & 50 \\
\hline 1138000 & $\begin{array}{l}\text { Ammonoosuc } \\
\text { River }\end{array}$ & Bath, N.H. & 15.58 & 13.86 & 7.081 & .1698 & 39.92 & .2646 & 2.849 & 31 \\
\hline 1139000 & Wells River & Wells River, Vt. & 16.38 & 15.96 & 3.376 & .3299 & 38.15 & .4278 & 3.288 & 50 \\
\hline 1139800 & $\begin{array}{l}\text { East Orange } \\
\text { Branch }\end{array}$ & East Orange, Vt. & 21.61 & 24.19 & -8.199 & .7754 & 41.77 & .5666 & 4.365 & 39 \\
\hline 1141800 & Mink Brook & Etna, N.H. & 16.57 & 19.26 & -11.52 & .7454 & 41.30 & .5609 & 3.618 & 34 \\
\hline 1142500 & Ayers Brook & Randolph, Vt. & 18.84 & 21.06 & -13.66 & .8679 & 40.00 & .7876 & 2.447 & 48 \\
\hline 1144000 & White River & West Hartford, Vt. & 18.70 & 19.46 & -7.003 & .6682 & 39.61 & .7301 & 2.316 & 50 \\
\hline 1145000 & Mascoma River & West Canaan, N.H. & 15.25 & 16.48 & -7.063 & .5816 & 40.47 & .8279 & 1.56 & 29 \\
\hline 1150900 & $\begin{array}{l}\text { Ottauquechee } \\
\text { River }\end{array}$ & West Bridgewater, Vt. & 27.01 & 31.84 & 4.29 & .5383 & 51.18 & .3289 & 4.768 & 13 \\
\hline 1153500 & Williams River & Brockways Mills, Vt. & 18.00 & 19.56 & -3.006 & .5164 & 43.70 & .6606 & 2.613 & 35 \\
\hline 1154000 & Saxtons River & Saxtons River, Vt. & 17.62 & 20.60 & -5.456 & .5755 & 45.28 & .7066 & 2.541 & 33 \\
\hline 1155000 & Cold River & Drewsville, N.H. & 22.81 & 16.21 & -6.244 & .5625 & 39.92 & .8048 & 1.804 & 29 \\
\hline 1155500 & West River & Jamaica, Vt. & 18.21 & 19.63 & 5.677 & .2993 & 46.61 & .3182 & 3.243 & 12 \\
\hline 1156000 & West River & Newfane, Vt. & 17.13 & 17.88 & 5.149 & .2794 & 45.55 & .2954 & 3.574 & 12 \\
\hline 1162500 & Priest Brook & Winchendon, Mass. & 21.54 & 21.72 & -13.55 & .821 & 42.95 & .8455 & 2.617 & 35 \\
\hline 1165500 & Moss Brook & Wendell Depot, Mass. & 17.17 & 18.26 & -12.4 & .7183 & 42.68 & .8943 & 1.762 & 33 \\
\hline 1167800 & Beaver Brook & Wilmington, Vt. & 23.54 & 28.12 & -4.808 & .6191 & 53.19 & .4168 & 4.553 & 12 \\
\hline 10965852 & Beaver Brook & North Pelham, N.H. & 19.36 & 19.85 & -9.46 & .6781 & 43.23 & .8836 & 1.617 & 11 \\
\hline
\end{tabular}


Table 4. Winter (January 1-March 15) normalized basin-recharge rates determined from basin-specific regression equations relating Rorabaugh-method-determined ground-water-recharge rates and basin-centroid precipitation.

[No., number; Location of stream-gaging stations are shown in figure 1 and reference numbers and descriptions of stream-gaging stations are listed in table 1; RORA, Recession-curve-displacement computer program; in., inch; $B_{0}, B_{1}, R^{2}$, regression model coefficients; MSE, Mean Square Error; NA, indicates that an entry is not applicable on the basis of the regression analysis]

\begin{tabular}{|c|c|c|c|c|c|c|c|c|c|c|}
\hline $\begin{array}{c}\text { Stream- } \\
\text { gaging } \\
\text { station } \\
\text { No. }\end{array}$ & River & Location & $\begin{array}{c}\text { Average } \\
\text { drainage- } \\
\text { basin } \\
\text { (RORA) } \\
\text { recharge } \\
\text { rate } \\
\text { (in/ } \\
\text { winter) }\end{array}$ & $\begin{array}{l}\text { Normal- } \\
\text { ized } \\
\text { drainage- } \\
\text { basin } \\
\text { recharge } \\
\text { rate } \\
\text { (in/ } \\
\text { winter) }\end{array}$ & $\boldsymbol{B}_{0}$ & $\boldsymbol{B}_{1}$ & $\begin{array}{c}\text { Normal- } \\
\text { ized } \\
\text { drainage- } \\
\text { basin- } \\
\text { centroid } \\
\text { precipi- } \\
\text { tation } \\
\text { (in/ } \\
\text { winter) }\end{array}$ & $\begin{array}{c}\text { Coeffi- } \\
\text { cient of } \\
\text { deter- } \\
\text { mination } \\
\left(R^{2}\right)\end{array}$ & $\begin{array}{l}\text { Root } \\
\text { MSE } \\
\text { (in.) }\end{array}$ & $\begin{array}{l}\text { Years } \\
\text { of } \\
\text { record }\end{array}$ \\
\hline 1052500 & Diamond River & Wentworth Location, N.H. & 3.07 & 3.07 & NA & NA & 7.46 & NA & NA & 50 \\
\hline 1054200 & Wild River & Gilead, Maine & 4.15 & 4.15 & NA & NA & 8.74 & NA & NA & 34 \\
\hline 1054300 & Ellis River & South Andover, Maine & 3.30 & 3.35 & 1.199 & 0.3109 & 6.91 & 0.1865 & 1.442 & 19 \\
\hline 1055000 & Swift River & Near Roxbury, Maine & 2.93 & 3.00 & 0.7297 & .3087 & 7.34 & .1396 & 1.591 & 50 \\
\hline 1057000 & $\begin{array}{l}\text { Little Androscog- } \\
\text { gin River }\end{array}$ & Near South Paris, Maine & 4.02 & 3.71 & 1.03 & .3551 & 7.56 & .2747 & 1.4986 & 50 \\
\hline 1064300 & Ellis River & Near Jackson, N.H. & 3.92 & 3.92 & NA & NA & 15.08 & NA & NA & 35 \\
\hline 1064400 & Lucy Brook & Near North Conway, N.H. & 4.54 & 4.54 & NA & NA & 10.35 & NA & NA & 28 \\
\hline 1064500 & Saco River & Near Conway, N.H. & 4.21 & 4.21 & NA & NA & 9.41 & NA & NA & 50 \\
\hline 1072850 & Mohawk River & Center Strafford, N.H. & 5.43 & 5.43 & NA & NA & 8.52 & NA & NA & 13 \\
\hline 1073000 & Oyster River & Durham, N.H. & 6.07 & 5.90 & 1.328 & .5837 & 7.83 & .5108 & 1.525 & 50 \\
\hline 1073600 & Dudley Brook & Exeter, N.H. & 3.94 & 3.95 & 1.493 & .2957 & 8.31 & .2637 & 1.376 & 23 \\
\hline 1075000 & $\begin{array}{l}\text { Pemigewasset } \\
\text { River }\end{array}$ & Woodstock, N.H. & 3.43 & 3.43 & NA & NA & 8.37 & NA & NA & 29 \\
\hline 1075800 & Stevens Brook & Wentworth, N.H. & 3.12 & 3.01 & .059 & .4218 & 7.01 & .2983 & 1.513 & 35 \\
\hline 1076000 & Baker River & Rumney, N.H. & 3.00 & 3.00 & NA & NA & 5.79 & NA & NA & 27 \\
\hline 1076500 & $\begin{array}{l}\text { Pemigewasset } \\
\text { River }\end{array}$ & Plymouth, N.H. & 3.65 & 3.65 & NA & NA & 8.92 & NA & NA & 50 \\
\hline 1078000 & Smith River & Near Bristol, N.H. & 3.97 & 4.08 & .471 & .4642 & 7.78 & .2012 & 1.943 & 50 \\
\hline 1082000 & Contoocook River & Peterborough, N.H. & 5.21 & 5.07 & 1.577 & .4199 & 8.33 & .1924 & 2.172 & 29 \\
\hline 1084500 & Beards Brook & Hillsboro, N.H. & 4.66 & 4.66 & NA & NA & 8.64 & NA & NA & 22 \\
\hline 1085800 & $\begin{array}{l}\text { West Branch } \\
\text { Warner River }\end{array}$ & Near Bradford, N.H. & 5.00 & 5.40 & -.1999 & .704 & 7.95 & .3729 & 1.899 & 36 \\
\hline 1086000 & Warner River & Davisville, N.H. & 4.94 & 4.94 & NA & NA & 8.31 & NA & NA & 30 \\
\hline 1089000 & Soucook River & Near Concord, N.H. & 4.63 & 4.32 & .6584 & .5451 & 6.71 & .2844 & 1.9 & 46 \\
\hline 1091000 & $\begin{array}{l}\text { South Branch } \\
\text { Piscataquog River }\end{array}$ & Near Goffstown, N.H. & 5.44 & 5.41 & 1.753 & .444 & 8.23 & .1928 & 2.043 & 30 \\
\hline 1093800 & $\begin{array}{l}\text { Stony Brook } \\
\text { Tributary }\end{array}$ & Near Temple, N.H. & 5.79 & 6.14 & .4268 & .6243 & 9.15 & .4247 & 1.827 & 35 \\
\hline 1097300 & Nashoba Brook & Near Acton, Mass. & 6.61 & 6.71 & .3797 & .718 & 8.82 & .4994 & 2.036 & 35 \\
\hline 1101000 & Parker River & Byfield, Mass. & 7.67 & 7.82 & .552 & .8057 & 9.02 & .5198 & 2.16 & 50 \\
\hline 1127880 & Big Brook & Pittsburg, N.H. & 3.00 & 4.47 & -1.878 & .8716 & 7.28 & .3469 & 1.756 & 21 \\
\hline 1129440 & Mohawk River & Near Colebrook, N.H. & 3.32 & 4.10 & -1.464 & .7922 & 7.03 & .4904 & 1.437 & 12 \\
\hline
\end{tabular}


Table 4. Winter (January 1-March 15) normalized basin-recharge rates determined from basin-specific regression equations relating Rorabaugh-method-determined ground-water-recharge rates and basin-centroid precipitation.-Continued

[No., number; Location of stream-gaging stations are shown in figure 1 and reference numbers and descriptions of stream-gaging stations are listed in table 1; RORA, Recession-curve-displacement computer program; in., inch; $B_{0}, B_{1}, R^{2}$, regression model coefficients; MSE, Mean Square Error; NA, indicates that an entry is not applicable on the basis of the regression analysis]

\begin{tabular}{|c|c|c|c|c|c|c|c|c|c|c|}
\hline $\begin{array}{c}\text { Stream- } \\
\text { gaging } \\
\text { station } \\
\text { No. }\end{array}$ & River & Location & $\begin{array}{c}\text { Average } \\
\text { drainage- } \\
\text { basin } \\
\text { (RORA) } \\
\text { recharge } \\
\text { rate } \\
\text { (in/ } \\
\text { winter) }\end{array}$ & $\begin{array}{l}\text { Normal- } \\
\text { ized } \\
\text { drainage- } \\
\text { basin } \\
\text { recharge } \\
\text { rate } \\
\text { (in/ } \\
\text { winter) }\end{array}$ & $\boldsymbol{B}_{0}$ & $\boldsymbol{B}_{1}$ & $\begin{array}{l}\text { Normal- } \\
\text { ized } \\
\text { drainage- } \\
\text { basin- } \\
\text { centroid } \\
\text { precipi- } \\
\text { tation } \\
\text { (in/ } \\
\text { winter) }\end{array}$ & $\begin{array}{c}\text { Coeffi- } \\
\text { cient of } \\
\text { deter- } \\
\text { mination } \\
\left(R^{2}\right)\end{array}$ & $\begin{array}{l}\text { Root } \\
\text { MSE } \\
\text { (in.) }\end{array}$ & $\begin{array}{l}\text { Years } \\
\text { of } \\
\text { record }\end{array}$ \\
\hline 1130000 & $\begin{array}{l}\text { Upper Ammo- } \\
\text { noosuc River }\end{array}$ & Near Groveton, N.H. & 3.27 & 3.27 & NA & NA & 6.28 & NA & NA & 48 \\
\hline 1133000 & $\begin{array}{l}\text { East Branch } \\
\text { Passumpsic }\end{array}$ & East Haven, Vt. & 3.41 & 3.41 & NA & NA & 6.42 & NA & NA & 31 \\
\hline 1134500 & Moose River & Victory, Vt. & 3.34 & 3.39 & 0.9687 & 0.341 & 7.11 & 0.0917 & 1.836 & 50 \\
\hline 1134800 & Kirby Brook & Concord, Vt. & 2.30 & 2.30 & NA & NA & 6.36 & NA & NA & 11 \\
\hline 1135000 & Moose River & St. Johnsbury, Vt. & 2.73 & 2.73 & NA & NA & 6.40 & NA & NA & 35 \\
\hline 1135300 & $\begin{array}{l}\text { Sleepers River } \\
\text { (W-5) }\end{array}$ & St. Johnsbury, Vt. & 3.55 & 3.43 & -1.287 & .7614 & 6.20 & .3943 & 1.019 & 10 \\
\hline 1137500 & $\begin{array}{l}\text { Ammonoosuc } \\
\text { River }\end{array}$ & Bethlehem Junction, N.H. & 3.32 & 3.32 & NA & NA & 10.28 & NA & NA & 50 \\
\hline 1138000 & $\begin{array}{l}\text { Ammonoosuc } \\
\text { River }\end{array}$ & Bath, N.H. & 2.47 & 2.47 & NA & NA & 6.04 & NA & NA & 32 \\
\hline 1139000 & Wells River & Wells River, Vt. & 3.20 & 3.05 & .4955 & .4415 & 5.79 & .2043 & 1.433 & 50 \\
\hline 1139800 & $\begin{array}{l}\text { East Orange } \\
\text { Branch }\end{array}$ & East Orange, Vt. & 3.70 & 3.88 & .154 & .5764 & 6.46 & .2346 & 1.896 & 40 \\
\hline 1141800 & Mink Brook & Etna, N.H. & 3.79 & 4.09 & .2161 & .5564 & 6.97 & .265 & 1.696 & 36 \\
\hline 1142500 & Ayers Brook & Randolph, Vt. & 4.34 & 4.40 & 1.095 & .4899 & 6.75 & .1759 & 1.848 & 49 \\
\hline 1144000 & White River & West Hartford, Vt. & 4.02 & 4.01 & 1.287 & .3981 & 6.85 & .1548 & 1.631 & 50 \\
\hline 1145000 & Mascoma River & West Canaan, N.H. & 3.20 & 3.20 & NA & NA & 6.57 & NA & NA & 30 \\
\hline 1150800 & Kent Brook & Sherburne, Vt. & 4.15 & 4.15 & NA & NA & 9.19 & NA & NA & 11 \\
\hline 1150900 & $\begin{array}{l}\text { Ottauquechee } \\
\text { River }\end{array}$ & West Bridgewater, Vt. & 6.05 & 7.51 & -2.197 & 1.133 & 8.56 & .6471 & 1.688 & 14 \\
\hline 1153500 & Williams River & Brockways Mills, Vt. & 4.45 & 4.45 & NA & NA & 7.72 & NA & NA & 36 \\
\hline 1154000 & Saxtons River & Saxtons River, Vt. & 4.58 & 4.72 & 1.869 & .348 & 8.19 & .1178 & 2.052 & 34 \\
\hline 1155000 & Cold River & Drewsville, N.H. & 3.67 & 3.59 & 1.176 & .3487 & 6.91 & .1309 & 1.612 & 30 \\
\hline 1155200 & Sacketts Brook & Putney, Vt. & 4.37 & 4.37 & NA & NA & 7.91 & NA & NA & 11 \\
\hline 1155300 & Flood Brook & Londonderry, Vt. & 4.01 & 4.01 & NA & NA & 9.09 & NA & NA & 11 \\
\hline 1155500 & West River & Jamaica, Vt. & 4.26 & 4.26 & NA & NA & 8.39 & NA & NA & 12 \\
\hline 1156000 & West River & Newfane, Vt. & 3.94 & 3.94 & NA & NA & 8.29 & NA & NA & 12 \\
\hline 1158500 & Otter Brook & Keene, N.H. & 5.56 & 5.56 & NA & NA & 7.76 & NA & NA & 10 \\
\hline 1162500 & Priest Brook & Winchendon, Mass. & 5.67 & 5.74 & -.8108 & .8135 & 8.05 & .5388 & 1.844 & 36 \\
\hline 1165500 & Moss Brook & Wendell Depot, Mass. & 4.95 & 4.91 & .6238 & .546 & 7.85 & .3585 & 1.744 & 34 \\
\hline 1167800 & Beaver Brook & Wilmington, Vt. & 4.85 & 4.85 & NA & NA & 9.92 & NA & NA & 14 \\
\hline 10965852 & Beaver Brook & North Pelham, N.H. & 5.79 & 6.71 & -1.017 & .9508 & 8.13 & .8884 & .8107 & 12 \\
\hline
\end{tabular}


Table 5. Spring (March 16-May 31) normalized basin-recharge rates determined from basin-specific regression equations relating Rorabaugh-method-determined ground-water-recharge rates and basin-centroid precipitation.

[No., number; Location of stream-gaging stations are shown in figure 1 and reference numbers and descriptions of stream-gaging stations are listed in table 1; RORA, Recession-curve-displacement computer program; in., inch; $B_{0}, B_{1}, R^{2}$, regression model coefficients; MSE, Mean Square Error; NA, indicates that an entry is not applicable on the basis of the regression analysis]

\begin{tabular}{|c|c|c|c|c|c|c|c|c|c|c|}
\hline $\begin{array}{c}\text { Stream- } \\
\text { gaging } \\
\text { station } \\
\text { No. }\end{array}$ & River & Location & 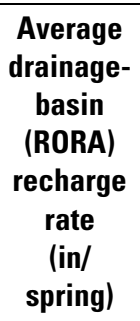 & $\begin{array}{c}\text { Normal- } \\
\text { ized } \\
\text { drainage- } \\
\text { basin } \\
\text { recharge } \\
\text { rate } \\
\text { (in/ } \\
\text { spring) }\end{array}$ & $\boldsymbol{B}_{0}$ & $\boldsymbol{B}_{1}$ & $\begin{array}{l}\text { Normal- } \\
\text { ized } \\
\text { drainage- } \\
\text { basin- } \\
\text { centroid } \\
\text { precipi- } \\
\text { tation } \\
\text { (in/spring) }\end{array}$ & $\begin{array}{c}\text { Coeffi- } \\
\text { cient of } \\
\text { determi- } \\
\text { nation } \\
\left(R^{2}\right)\end{array}$ & $\begin{array}{c}\text { Root } \\
\text { MSE } \\
\text { (in.) }\end{array}$ & $\begin{array}{l}\text { Years } \\
\text { of } \\
\text { record }\end{array}$ \\
\hline 1052500 & Diamond River & Wentworth Location, N.H. & 11.16 & 12.06 & 7.05 & 0.5445 & 9.19 & 0.1073 & 3.046 & 50 \\
\hline 1054200 & Wild River & Gilead, Maine & 10.95 & 10.02 & 7.119 & .2877 & 10.08 & .2626 & 2.96 & 34 \\
\hline 1054300 & Ellis River & South Andover, Maine & 10.04 & 10.04 & NA & NA & 7.85 & NA & NA & 20 \\
\hline 1055000 & Swift River & Near Roxbury, Maine & 9.99 & 10.24 & 6.836 & .3886 & 8.76 & .1632 & 2.45 & 50 \\
\hline 1057000 & $\begin{array}{l}\text { Little Androscog- } \\
\text { gin River }\end{array}$ & Near South Paris, Maine & 8.78 & 8.65 & 4.877 & .422 & 8.94 & .3245 & 2.281 & 50 \\
\hline 1064300 & Ellis River & Near Jackson, N.H. & 14.35 & 13.25 & 7.106 & .3981 & 15.43 & .5123 & 2.854 & 35 \\
\hline 1064400 & Lucy Brook & Near North Conway, N.H. & 10.93 & 10.51 & 6.237 & .3767 & 11.34 & .3453 & 2.787 & 27 \\
\hline 1064500 & Saco River & Near Conway, N.H. & 12.39 & 11.75 & 7.304 & .4228 & 10.51 & .2841 & 3.189 & 50 \\
\hline 1072850 & Mohawk River & Center Strafford, N.H. & 7.61 & 7.61 & NA & NA & 9.98 & NA & NA & 13 \\
\hline 1073000 & Oyster River & Durham, N.H. & 7.31 & 7.61 & 2.577 & .5418 & 9.29 & .4037 & 2.08 & 50 \\
\hline 1073600 & Dudley Brook & Exeter, N.H. & 4.66 & 5.16 & .211 & .5308 & 9.33 & .5714 & 1.585 & 23 \\
\hline 1075000 & $\begin{array}{l}\text { Pemigewasset } \\
\text { River }\end{array}$ & Woodstock, N.H. & 13.57 & 13.68 & 9.289 & .4333 & 10.14 & .1906 & 2.897 & 29 \\
\hline 1075800 & Stevens Brook & Wentworth, N.H. & 6.06 & 6.03 & 2.995 & .3634 & 8.35 & .2112 & 1.962 & 35 \\
\hline 1076000 & Baker River & Rumney, N.H. & 8.80 & 8.74 & 5.5 & .4314 & 7.52 & .282 & 1.809 & 27 \\
\hline 1076500 & $\begin{array}{l}\text { Pemigewasset } \\
\text { River }\end{array}$ & Plymouth, N.H. & 9.95 & 10.42 & 6.585 & .3794 & 10.10 & .1572 & 2.46 & 50 \\
\hline 1078000 & Smith River & Near Bristol, N.H. & 8.43 & 8.86 & 4.399 & .4755 & 9.39 & .2608 & 2.365 & 50 \\
\hline 1082000 & Contoocook River & Peterborough, N.H. & 8.18 & 8.38 & 3.877 & .4874 & 9.23 & .2014 & 2.552 & 29 \\
\hline 1084500 & Beards Brook & Hillsboro, N.H. & 8.20 & 9.10 & 4.505 & .4642 & 9.90 & .1789 & 2.557 & 22 \\
\hline 1085800 & $\begin{array}{l}\text { West Branch } \\
\text { Warner River }\end{array}$ & Near Bradford, N.H. & 8.74 & 9.38 & 4.029 & .5477 & 9.76 & .3185 & 2.356 & 36 \\
\hline 1086000 & Warner River & Davisville, N.H. & 9.64 & 10.38 & 5.103 & .5491 & 9.61 & .271 & 2.45 & 30 \\
\hline 1089000 & Soucook River & Near Concord, N.H. & 6.66 & 6.55 & 3.277 & .4088 & 8.01 & .346 & 1.715 & 47 \\
\hline 1091000 & $\begin{array}{l}\text { South Branch } \\
\text { Piscataquog River }\end{array}$ & Near Goffstown, N.H. & 7.69 & 7.99 & 3.999 & .4366 & 9.13 & .2198 & 2.187 & 30 \\
\hline 1093800 & $\begin{array}{l}\text { Stony Brook } \\
\text { Tributary }\end{array}$ & Near Temple, N.H. & 8.79 & 9.34 & 2.006 & .7156 & 10.26 & .4068 & 2.774 & 35 \\
\hline 1097300 & Nashoba Brook & Near Acton, Mass. & 6.57 & 6.66 & 2.274 & .4725 & 9.29 & .2969 & 2.262 & 35 \\
\hline 1101000 & Parker River & Byfield, Mass. & 8.09 & 8.77 & .1891 & .9039 & 9.49 & .5645 & 2.478 & 50 \\
\hline 1127880 & Big Brook & Pittsburg, N.H. & 12.42 & 12.42 & NA & NA & 9.21 & NA & NA & 21 \\
\hline 1129440 & Mohawk River & Near Colebrook, N.H. & 6.99 & 6.99 & NA & NA & 8.68 & NA & NA & 12 \\
\hline
\end{tabular}


Table 5. Spring (March 16-May 31) normalized basin-recharge rates determined from basin-specific regression equations relating Rorabaugh-method-determined ground-water-recharge rates and basin-centroid precipitation.-Continued

[No., number; Location of stream-gaging stations are shown in figure 1 and reference numbers and descriptions of stream-gaging stations are listed in table 1; RORA, Recession-curve-displacement computer program; in., inch; $B_{0}, B_{1}, R^{2}$, regression model coefficients; MSE, Mean Square Error; NA, indicates that an entry is not applicable on the basis of the regression analysis]

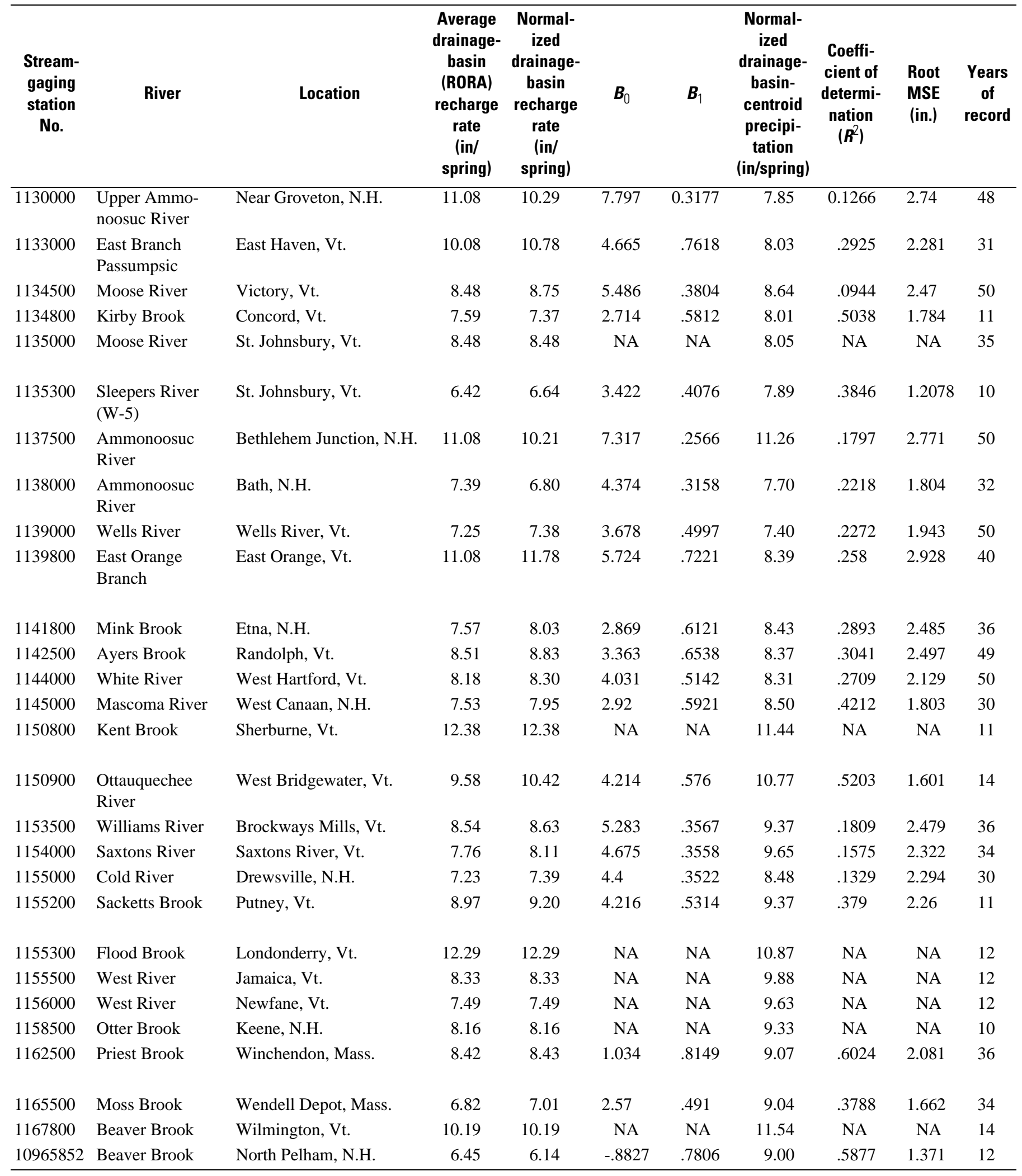


Table 6. Summer (June 1-0ctober 31) normalized basin-recharge rates determined from basin-specific regression equations relating Rorabaugh-method-determined ground-water-recharge rates and basin-centroid precipitation.

[No., number; Location of stream-gaging stations are shown in figure 1 and reference numbers and descriptions of stream-gaging stations are listed in table 1; RORA, Recession-curve-displacement computer program; in., inch; $B_{0}, B_{1}, R^{2}$, regression model coefficients; MSE, Mean Square Error; NA, indicates that an entry is not applicable on the basis of the regression analysis]

\begin{tabular}{|c|c|c|c|c|c|c|c|c|c|c|}
\hline $\begin{array}{c}\text { Stream- } \\
\text { gaging } \\
\text { station } \\
\text { No. }\end{array}$ & River & Location & $\begin{array}{c}\text { Average } \\
\text { drainage- } \\
\text { basin } \\
\text { (RORA) } \\
\text { recharge } \\
\text { rate } \\
\text { (in/ } \\
\text { summer) }\end{array}$ & $\begin{array}{l}\text { Normal- } \\
\text { ized } \\
\text { drainage- } \\
\text { basin } \\
\text { recharge } \\
\text { rate } \\
\text { (in/ } \\
\text { summer) }\end{array}$ & $\boldsymbol{B}_{0}$ & $\boldsymbol{B}_{1}$ & $\begin{array}{c}\text { Normal- } \\
\text { ized } \\
\text { drainage- } \\
\text { basin- } \\
\text { centroid } \\
\text { precipi- } \\
\text { tation } \\
\text { (in/ } \\
\text { summer) }\end{array}$ & $\begin{array}{c}\text { Coeffi- } \\
\text { cient of } \\
\text { determi- } \\
\text { nation } \\
\left(R^{2}\right)\end{array}$ & $\begin{array}{l}\text { Root } \\
\text { MSE } \\
\text { (in.) }\end{array}$ & $\begin{array}{l}\text { Years } \\
\text { of } \\
\text { record }\end{array}$ \\
\hline 1052500 & Diamond River & Wentworth Location, N.H. & 4.20 & 6.69 & -6.493 & 0.5742 & 22.95 & 0.618 & 1.621 & 50 \\
\hline 1054200 & Wild River & Gilead, Maine & 4.39 & 3.80 & .8721 & .1366 & 21.46 & .1986 & 1.903 & 34 \\
\hline 1054300 & Ellis River & South Andover, Maine & 3.70 & 3.22 & -5.233 & .5112 & 16.54 & .7273 & 1.21 & 19 \\
\hline 1055000 & Swift River & Near Roxbury, Maine & 3.62 & 4.12 & -4.151 & .4315 & 19.17 & .5708 & 1.551 & 50 \\
\hline 1057000 & $\begin{array}{l}\text { Little Androscog- } \\
\text { gin River }\end{array}$ & Near South Paris, Maine & 3.20 & 3.03 & -2.049 & 2746 & 18.50 & .4074 & 1.706 & 50 \\
\hline 1064300 & Ellis River & Near Jackson, N.H. & 10.43 & 9.37 & 1.991 & .2447 & 30.16 & .2204 & 2.733 & 35 \\
\hline 1064400 & Lucy Brook & Near North Conway, N.H. & 4.78 & 3.85 & -3.944 & .3511 & 22.20 & .417 & 2.593 & 28 \\
\hline 1064500 & Saco River & Near Conway, N.H. & 5.21 & 3.71 & -2.479 & .303 & 20.43 & .5118 & 1.8426 & 50 \\
\hline 1072850 & Mohawk River & Center Strafford, N.H. & 1.59 & 1.59 & NA & NA & 18.86 & NA & NA & 13 \\
\hline 1073000 & Oyster River & Durham, N.H. & 2.41 & 2.78 & -3.109 & .3422 & 17.20 & .5117 & 1.277 & 50 \\
\hline 1073600 & Dudley Brook & Exeter, N.H. & 0.96 & 1.45 & -2.052 & .2 & 17.52 & .3183 & .9713 & 24 \\
\hline 1075000 & $\begin{array}{l}\text { Pemigewasset } \\
\text { River }\end{array}$ & Woodstock, N.H. & 5.57 & 6.21 & -3.835 & .4407 & 22.80 & .7426 & 1.033 & 28 \\
\hline 1075800 & Stevens Brook & Wentworth, N.H. & 1.78 & 1.69 & -3.665 & .2954 & 18.11 & .6123 & .8916 & 35 \\
\hline 1076000 & Baker River & Rumney, N.H. & 2.79 & 3.26 & -2.682 & .34 & 17.48 & .6649 & .9294 & 27 \\
\hline 1076500 & $\begin{array}{l}\text { Pemigewasset } \\
\text { River }\end{array}$ & Plymouth, N.H. & 4.78 & 4.92 & -3.584 & .4262 & 19.96 & .6857 & 1.26 & 50 \\
\hline 1078000 & Smith River & Near Bristol, N.H. & 3.01 & 3.87 & -4.406 & .4417 & 18.74 & .732 & .9431 & 50 \\
\hline 1082000 & Contoocook River & Peterborough, N.H. & 3.16 & 3.62 & -3.131 & .3648 & 18.50 & .7441 & 1.077 & 28 \\
\hline 1084500 & Beards Brook & Hillsboro, N.H. & 1.93 & 3.01 & -2.795 & .3045 & 19.06 & .7597 & .7414 & 21 \\
\hline 1085800 & $\begin{array}{l}\text { West Branch } \\
\text { Warner River }\end{array}$ & Near Bradford, N.H. & 2.73 & 3.58 & -3.488 & .3695 & 19.13 & .6207 & 1.248 & 37 \\
\hline 1086000 & Warner River & Davisville, N.H. & 2.25 & 3.09 & -3.567 & .367 & 18.15 & .8079 & .7444 & 30 \\
\hline 1089000 & Soucook River & Near Concord, N.H. & 2.48 & 2.62 & -4.009 & .3922 & 16.89 & .67 & .9359 & 46 \\
\hline 1091000 & $\begin{array}{l}\text { South Branch } \\
\text { Piscataquog River }\end{array}$ & Near Goffstown, N.H. & 2.29 & 2.62 & -2.691 & .2996 & 17.72 & .6975 & .8388 & 29 \\
\hline 1093800 & $\begin{array}{l}\text { Stony Brook } \\
\text { Tributary }\end{array}$ & Near Temple, N.H. & 3.16 & 3.71 & -3.417 & .3629 & 19.65 & .569 & 1.426 & 35 \\
\hline 1097300 & Nashoba Brook & Near Acton, Mass. & 2.72 & 2.82 & -2.961 & .3316 & 17.44 & .5809 & 1.255 & 35 \\
\hline 1101000 & Parker River & Byfield, Mass. & 3.15 & 3.95 & -6.665 & .6117 & 17.36 & .5716 & 2.359 & 50 \\
\hline 1127880 & Big Brook & Pittsburg, N.H. & 6.72 & 10.17 & -5.646 & .6609 & 23.94 & .7253 & 1.53 & 21 \\
\hline 1129440 & Mohawk River & Near Colebrook, N.H. & 4.93 & 5.45 & -1.019 & .2966 & 21.81 & .6024 & .8687 & 12 \\
\hline
\end{tabular}


Table 6. Summer (June 1-0ctober 31) normalized basin-recharge rates determined from basin-specific regression equations relating Rorabaugh-method-determined ground-water-recharge rates and basin-centroid precipitation.-Continued

[No., number; Location of stream-gaging stations are shown in figure 1 and reference numbers and descriptions of stream-gaging stations are listed in table 1; RORA, Recession-curve-displacement computer program; in., inch; $B_{0}, B_{1}, R^{2}$, regression model coefficients; MSE, Mean Square Error; NA, indicates that an entry is not applicable on the basis of the regression analysis]

\begin{tabular}{|c|c|c|c|c|c|c|c|c|c|c|}
\hline $\begin{array}{c}\text { Stream- } \\
\text { gaging } \\
\text { station } \\
\text { No. }\end{array}$ & River & Location & $\begin{array}{c}\text { Average } \\
\text { drainage- } \\
\text { basin } \\
\text { (RORA) } \\
\text { recharge } \\
\text { rate } \\
\text { (in/ } \\
\text { summer) }\end{array}$ & $\begin{array}{l}\text { Normal- } \\
\text { ized } \\
\text { drainage- } \\
\text { basin } \\
\text { recharge } \\
\text { rate } \\
\text { (in/ } \\
\text { summer) }\end{array}$ & $\boldsymbol{B}_{0}$ & $\boldsymbol{B}_{1}$ & $\begin{array}{l}\text { Normal- } \\
\text { ized } \\
\text { drainage- } \\
\text { basin- } \\
\text { centroid } \\
\text { precipi- } \\
\text { tation } \\
\text { (in/ } \\
\text { summer) }\end{array}$ & $\begin{array}{l}\text { Coeffi- } \\
\text { cient of } \\
\text { determi- } \\
\text { nation } \\
\left(R^{2}\right)\end{array}$ & $\begin{array}{l}\text { Root } \\
\text { MSE } \\
\text { (in.) }\end{array}$ & $\begin{array}{l}\text { Years } \\
\text { of } \\
\text { record }\end{array}$ \\
\hline 1130000 & $\begin{array}{l}\text { Upper Ammo- } \\
\text { noosuc River }\end{array}$ & Near Groveton, N.H. & 4.75 & 3.18 & -4.27 & 0.3999 & 18.62 & 0.5453 & 1.704 & 48 \\
\hline 1133000 & $\begin{array}{l}\text { East Branch } \\
\text { Passumpsic }\end{array}$ & East Haven, Vt. & 5.93 & 7.40 & -2.611 & .4871 & 20.55 & .5185 & 1.651 & 30 \\
\hline 1134500 & Moose River & Victory, Vt. & 3.75 & 4.45 & -3.12 & .3585 & 21.10 & .4637 & 1.416 & 50 \\
\hline 1134800 & Kirby Brook & Concord, Vt. & 1.80 & 3.37 & -5.615 & .445 & 20.20 & .6717 & .892 & 10 \\
\hline 1135000 & Moose River & St. Johnsbury, Vt. & 2.96 & 3.55 & -3.122 & .331 & 20.16 & .5221 & 1.236 & 34 \\
\hline 1135300 & $\begin{array}{l}\text { Sleepers River } \\
(\mathrm{W}-5)\end{array}$ & St. Johnsbury, Vt. & 3.95 & 4.19 & -4.096 & .4246 & 19.53 & .4868 & 1.483 & 10 \\
\hline 1137500 & $\begin{array}{l}\text { Ammonoosuc } \\
\text { River }\end{array}$ & Bethlehem Junction, N.H. & 5.05 & 2.66 & -5.726 & .3485 & 24.06 & .585 & 1.723 & 50 \\
\hline 1138000 & $\begin{array}{l}\text { Ammonoosuc } \\
\text { River }\end{array}$ & Bath, N.H. & 2.93 & 2.38 & -4.312 & .3504 & 19.09 & .7513 & .7427 & 31 \\
\hline 1139000 & Wells River & Wells River, Vt. & 3.33 & 3.81 & -4.67 & .4662 & 18.19 & .7367 & 1.036 & 50 \\
\hline 1139800 & $\begin{array}{l}\text { East Orange } \\
\text { Branch }\end{array}$ & East Orange, Vt. & 3.53 & 4.59 & -6.549 & .5749 & 19.37 & .6441 & 1.778 & 40 \\
\hline 1141800 & Mink Brook & Etna, N.H. & 2.38 & 3.67 & -6.297 & .5338 & 18.66 & .6616 & 1.364 & 35 \\
\hline 1142500 & Ayers Brook & Randolph, Vt. & 3.04 & 3.30 & -5.895 & .5192 & 17.72 & .7498 & 1.219 & 49 \\
\hline 1144000 & White River & West Hartford, Vt. & 3.26 & 3.26 & -4.409 & .4458 & 17.20 & .7717 & 1.036 & 50 \\
\hline 1145000 & Mascoma River & West Canaan, N.H. & 2.08 & 2.72 & -2.943 & .3114 & 18.19 & .7543 & .6276 & 29 \\
\hline 1150800 & Kent Brook & Sherburne, Vt. & 3.76 & 8.83 & -4.667 & .5449 & 24.76 & .5023 & 1.392 & 10 \\
\hline 1150900 & $\begin{array}{l}\text { Ottauquechee } \\
\text { River }\end{array}$ & West Bridgewater, Vt. & 6.80 & 7.93 & -3.968 & .5202 & 22.87 & .5827 & 2.148 & 14 \\
\hline 1153500 & Williams River & Brockways Mills, Vt. & 2.41 & 3.26 & -3.832 & .3786 & 18.74 & .8291 & .7728 & 35 \\
\hline 1154000 & Saxtons River & Saxtons River, Vt. & 2.28 & 3.33 & -3.767 & .3687 & 19.25 & .8514 & 6909 & 33 \\
\hline 1155000 & Cold River & Drewsville, N.H. & 2.02 & 2.54 & -3.115 & .3207 & 17.64 & .8032 & 6769 & 29 \\
\hline 1155200 & Sacketts Brook & Putney, Vt. & 2.47 & 3.55 & -1.687 & .2835 & 18.46 & .3769 & 1.171 & 11 \\
\hline 1155300 & Flood Brook & Londonderry, Vt. & 3.24 & 3.24 & NA & NA & 22.01 & NA & NA & 11 \\
\hline 1155500 & West River & Jamaica, Vt. & 2.50 & 3.70 & -4.259 & .397 & 20.04 & .6241 & 1.144 & 12 \\
\hline 1156000 & West River & Newfane, Vt. & 2.62 & 3.67 & -4.649 & .4252 & 19.57 & .5436 & 1.628 & 12 \\
\hline 1162500 & Priest Brook & Winchendon, Mass. & 3.60 & 3.89 & -5.896 & .539 & 18.15 & .7806 & 1.291 & 36 \\
\hline 1165500 & Moss Brook & Wendell Depot, Mass. & 2.49 & 2.90 & -4.727 & .4229 & 18.03 & .7739 & 1.009 & 33 \\
\hline 1167800 & Beaver Brook & Wilmington, Vt. & 3.23 & 4.66 & -3.957 & .3921 & 21.97 & .697 & 1.364 & 14 \\
\hline 10965852 & Beaver Brook & North Pelham, N.H. & 3.18 & 2.92 & -3.824 & .3797 & 17.76 & .79 & .9628 & 12 \\
\hline
\end{tabular}


Table 7. Fall (November 1-December 31) normalized basin-recharge rates determined from basin-specific regression equations relating Rorabaugh-method-determined ground-water-recharge rates and basin-centroid precipitation.

[No., number; Location of stream-gaging stations are shown in figure 1 and reference numbers and descriptions of stream-gaging stations are listed in table 1 ; RORA, Recession-curve-displacement computer program; in., inch; $B_{0}, B_{1}, R^{2}$, regression model coefficients; MSE, Mean Square Error]

\begin{tabular}{|c|c|c|c|c|c|c|c|c|c|c|}
\hline $\begin{array}{c}\text { Stream- } \\
\text { gaging } \\
\text { station } \\
\text { No. }\end{array}$ & River & Location & $\begin{array}{c}\text { Average } \\
\text { drainage- } \\
\text { basin } \\
\text { (RORA) } \\
\text { recharge } \\
\text { rate } \\
\text { (in/fall) }\end{array}$ & $\begin{array}{l}\text { Normal- } \\
\text { ized } \\
\text { drainage- } \\
\text { basin } \\
\text { recharge } \\
\text { rate } \\
\text { (in/fall) }\end{array}$ & $\boldsymbol{B}_{0}$ & $\boldsymbol{B}_{1}$ & $\begin{array}{l}\text { Normal- } \\
\text { ized } \\
\text { drainage- } \\
\text { basin- } \\
\text { centroid } \\
\text { precipi- } \\
\text { tation } \\
\text { (in/fall) }\end{array}$ & $\begin{array}{c}\text { Coeffi- } \\
\text { cient of } \\
\text { determi- } \\
\text { nation } \\
\left(R^{2}\right)\end{array}$ & $\begin{array}{c}\text { Root } \\
\text { MSE } \\
\text { (in.) }\end{array}$ & $\begin{array}{c}\text { Years } \\
\text { of } \\
\text { record }\end{array}$ \\
\hline 1054200 & Wild River & Gilead, Maine & 3.52 & 2.93 & .5119 & .2549 & 9.49 & .592 & 1.016 & 35 \\
\hline 1054300 & Ellis River & South Andover, Maine & 3.26 & 3.08 & -1.401 & .5776 & 7.76 & .7967 & .9909 & 19 \\
\hline 1055000 & Swift River & Near Roxbury, Maine & 3.05 & 3.40 & .459 & .3574 & 8.23 & .5088 & 1.009 & 50 \\
\hline 1057000 & $\begin{array}{l}\text { Little Androscog- } \\
\text { gin River }\end{array}$ & Near South Paris, Maine & 3.52 & 3.69 & -.7569 & .5107 & 8.70 & .7006 & 1.053 & 50 \\
\hline 1064500 & Saco River & Near Conway, N.H. & 4.25 & 3.95 & 1.211 & .2796 & 9.80 & .2409 & 1.827 & 50 \\
\hline 1072850 & Mohawk River & Center Strafford, N.H. & 3.78 & 4.23 & -2.092 & .6506 & 9.72 & .7543 & 1.325 & 13 \\
\hline 1073000 & Oyster River & Durham, N.H. & 3.76 & 4.02 & -.9709 & .5611 & 8.90 & .6573 & 1.262 & 50 \\
\hline 1073600 & Dudley Brook & Exeter, N.H. & 2.32 & 2.39 & -.4265 & .3148 & 8.94 & .5323 & 1.12 & 24 \\
\hline 1075000 & $\begin{array}{l}\text { Pemigewasset } \\
\text { River }\end{array}$ & Woodstock, N.H. & 4.20 & 4.00 & .8289 & .3477 & 9.13 & .4765 & 1.397 & 28 \\
\hline 1075800 & Stevens Brook & Wentworth, N.H. & 2.30 & 2.36 & -.0902 & .3205 & 7.64 & .5451 & .7472 & 35 \\
\hline 1076000 & Baker River & Rumney, N.H. & 3.08 & 2.81 & -.0581 & .4361 & 6.57 & .5795 & .9619 & 27 \\
\hline 1076500 & $\begin{array}{l}\text { Pemigewasset } \\
\text { River }\end{array}$ & Plymouth, N.H. & 3.87 & 4.45 & 1.008 & .3572 & 9.65 & .3701 & 1.29 & 50 \\
\hline 1086000 & Warner River & Davisville, N.H. & 3.76 & 4.26 & -1.027 & .6134 & 8.62 & .5742 & 1.49 & 30 \\
\hline 1089000 & Soucook River & Near Concord, N.H. & 3.19 & 2.96 & -.793 & .5264 & 7.13 & .567 & 1.157 & 45 \\
\hline 1091000 & $\begin{array}{l}\text { South Branch } \\
\text { Piscataquog River }\end{array}$ & Near Goffstown, N.H. & 3.68 & 3.66 & -.8575 & .5386 & 8.39 & .5771 & 1.349 & 29 \\
\hline 1093800 & $\begin{array}{l}\text { Stony Brook } \\
\text { Tributary }\end{array}$ & Near Temple, N.H. & 4.37 & 4.90 & -.8017 & .6159 & 9.25 & .5317 & 1.646 & 36 \\
\hline 1097300 & Nashoba Brook & Near Acton, Mass. & 3.59 & 3.82 & -.4937 & .5008 & 8.62 & .4494 & 1.709 & 36 \\
\hline 1101000 & Parker River & Byfield, Mass. & 4.26 & 4.84 & -1.511 & 698 & 9.09 & .5341 & 1.899 & 50 \\
\hline 1127880 & Big Brook & Pittsburg, N.H. & 3.61 & 4.82 & -1.556 & .7428 & 8.58 & .7023 & 1.001 & 21 \\
\hline 1129440 & Mohawk River & Near Colebrook, N.H. & 3.30 & 4.07 & .6765 & .4269 & 7.95 & .3443 & .7948 & 12 \\
\hline 1130000 & $\begin{array}{l}\text { Upper Ammo- } \\
\text { noosuc River }\end{array}$ & Near Groveton, N.H. & 3.27 & 2.55 & .4125 & .301 & 7.09 & .4478 & 1.137 & 47 \\
\hline
\end{tabular}


Table 7. Fall (November 1-December 31) normalized basin-recharge rates determined from basin-specific regression equations relating Rorabaugh-method-determined ground-water-recharge rates and basin-centroid precipitation.-Continued

[No., number; Location of stream-gaging stations are shown in figure 1 and reference numbers and descriptions of stream-gaging stations are listed in table 1; RORA, Recession-curve-displacement computer program; in., inch; $B_{0}, B_{1}, R^{2}$, regression model coefficients; MSE, Mean Square Error]

\begin{tabular}{|c|c|c|c|c|c|c|c|c|c|c|}
\hline $\begin{array}{c}\text { Stream- } \\
\text { gaging } \\
\text { station } \\
\text { No. }\end{array}$ & River & Location & $\begin{array}{c}\text { Average } \\
\text { drainage- } \\
\text { basin } \\
\text { (RORA) } \\
\text { recharge } \\
\text { rate } \\
\text { (in/fall) }\end{array}$ & $\begin{array}{l}\text { Normal- } \\
\text { ized } \\
\text { drainage- } \\
\text { basin } \\
\text { recharge } \\
\text { rate } \\
\text { (in/fall) }\end{array}$ & $\boldsymbol{B}_{0}$ & $\boldsymbol{B}_{1}$ & $\begin{array}{c}\text { Normal- } \\
\text { ized } \\
\text { drainage- } \\
\text { basin- } \\
\text { centroid } \\
\text { precipi- } \\
\text { tation } \\
\text { (in/fall) }\end{array}$ & $\begin{array}{c}\text { Coeffi- } \\
\text { cient of } \\
\text { determi- } \\
\text { nation } \\
\left(R^{2}\right)\end{array}$ & $\begin{array}{l}\text { Root } \\
\text { MSE } \\
\text { (in.) }\end{array}$ & $\begin{array}{l}\text { Years } \\
\text { of } \\
\text { record }\end{array}$ \\
\hline$\overline{1133000}$ & $\begin{array}{l}\text { East Branch } \\
\text { Passumpsic }\end{array}$ & East Haven, Vt. & 3.65 & 4.26 & 0.2195 & 0.5429 & 7.44 & 0.5339 & 0.9964 & 30 \\
\hline 1134500 & Moose River & Victory, Vt. & 3.00 & 3.31 & 3.905 & 3657 & 7.99 & .4275 & .9908 & 50 \\
\hline 1134800 & Kirby Brook & Concord, Vt. & 2.47 & 2.26 & -.0497 & .3123 & 7.40 & .4233 & 1.051 & 11 \\
\hline 1135000 & Moose River & St. Johnsbury, Vt. & 2.45 & 2.58 & -.301 & .3909 & 7.36 & .5309 & .8303 & 34 \\
\hline 1135300 & $\begin{array}{l}\text { Sleepers River } \\
(\mathrm{W}-5)\end{array}$ & St. Johnsbury, Vt. & 2.77 & 3.95 & -.6378 & .6234 & 7.36 & .6665 & .6636 & 11 \\
\hline 1137500 & $\begin{array}{l}\text { Ammonoosuc } \\
\text { River }\end{array}$ & Bethlehem Junction, N.H. & 3.49 & 3.02 & 1.307 & .1586 & 10.79 & .252 & 1.419 & 50 \\
\hline 1138000 & $\begin{array}{l}\text { Ammonoosuc } \\
\text { River }\end{array}$ & Bath, N.H. & 2.68 & 2.21 & .5487 & .2362 & 7.05 & .3869 & 1.034 & 31 \\
\hline 1139000 & Wells River & Wells River, Vt. & 2.66 & 2.85 & -.0705 & .4294 & 6.81 & .5261 & .8523 & 50 \\
\hline 1139800 & $\begin{array}{l}\text { East Orange } \\
\text { Branch }\end{array}$ & East Orange, Vt. & 3.28 & 3.58 & .5834 & .4097 & 7.32 & .2833 & 1.485 & 41 \\
\hline 1141800 & Mink Brook & Etna, N.H. & 2.81 & 2.99 & .1312 & .4034 & 7.09 & .4205 & 1.16 & 36 \\
\hline 1142500 & Ayers Brook & Randolph, Vt. & 3.06 & 3.33 & -.979 & .5921 & 7.28 & .616 & 1.033 & 49 \\
\hline 1144000 & White River & West Hartford, Vt. & 3.22 & 3.37 & -.104 & .4775 & 7.28 & .5852 & .8836 & 50 \\
\hline 1145000 & Mascoma River & West Canaan, N.H. & 2.63 & 2.63 & -.5159 & .4389 & 7.17 & 6086 & .8666 & 29 \\
\hline 1150800 & Kent Brook & Sherburne, Vt. & 5.67 & 6.06 & 2.174 & 4084 & 9.53 & .7026 & .7937 & 10 \\
\hline 1150900 & $\begin{array}{l}\text { Ottauquechee } \\
\text { River }\end{array}$ & West Bridgewater, Vt. & 4.59 & 5.22 & .4852 & .5278 & 8.98 & .3392 & 1.028 & 14 \\
\hline 1153500 & Williams River & Brockways Mills, Vt. & 2.79 & 2.82 & -.5874 & .4389 & 7.76 & .6414 & .9479 & 35 \\
\hline 1154000 & Saxtons River & Saxtons River, Vt. & 3.03 & 3.23 & -.9633 & .5224 & 8.03 & .6564 & 1.084 & 33 \\
\hline 1155000 & Cold River & Drewsville, N.H. & 2.70 & 2.44 & -.9445 & .4936 & 6.85 & .7058 & .8244 & 29 \\
\hline 1155200 & Sacketts Brook & Putney, Vt. & 3.21 & 2.81 & -.6236 & .4432 & 7.76 & 6091 & 1.263 & 11 \\
\hline 1155300 & Flood Brook & Londonderry, Vt. & 4.30 & 4.08 & .3825 & .4159 & 8.90 & .5501 & 1.188 & 11 \\
\hline 1155500 & West River & Jamaica, Vt. & 3.15 & 3.44 & -1.327 & .5824 & 8.19 & .8769 & .5679 & 12 \\
\hline 1156000 & West River & Newfane, Vt. & 3.02 & 2.99 & -2.857 & .7347 & 7.95 & .8399 & .8361 & 12 \\
\hline 1162500 & Priest Brook & Winchendon, Mass. & 3.84 & 3.73 & -1.556 & .6856 & 7.72 & .6154 & 1.412 & 36 \\
\hline 1165500 & Moss Brook & Wendell Depot, Mass. & 2.95 & 2.96 & -.9453 & .52 & 7.52 & .5741 & 1.157 & 33 \\
\hline 1167800 & Beaver Brook & Wilmington, Vt. & 4.72 & 4.95 & -.354 & .5386 & 9.84 & .627 & 1.483 & 14 \\
\hline 10965852 & Beaver Brook & North Pelham, N.H. & 3.95 & 4.59 & -.5126 & .6086 & 8.39 & .3561 & 1.647 & 12 \\
\hline
\end{tabular}


Table 9. Ground-water-recharge statistics, standard error of prediction, and 90-percent prediction interval estimated using available data and regression-equation predicted values for the annual period (January 1-December 31).

[No., number; fig., figure; in., inch; --, no data]

\begin{tabular}{|c|c|c|c|c|c|c|c|c|c|c|}
\hline $\begin{array}{c}\text { Stream- } \\
\text { gaging } \\
\text { station } \\
\text { refer- } \\
\text { ence } \\
\text { No. } \\
\text { (fig. 1) }\end{array}$ & $\begin{array}{c}\text { Stream- } \\
\text { gaging } \\
\text { station } \\
\text { No. }\end{array}$ & $\begin{array}{l}\text { Latitude } \\
\text { (decimal } \\
\text { degrees) }\end{array}$ & $\begin{array}{c}\text { Longitude } \\
\text { (decimal } \\
\text { degrees) }\end{array}$ & River name & Location & \multicolumn{3}{|c|}{$\begin{array}{c}\text { Annual } \\
\text { (January 1-December 31) }\end{array}$} & \multicolumn{2}{|c|}{$\begin{array}{l}\text { 90-percent } \\
\text { prediction } \\
\text { intervals }\end{array}$} \\
\hline 1 & 1052500 & 44.8778 & 71.0569 & Diamond River & Wentworth Location, N.H. & 23.1 & 22.9 & 2.59 & 27.2 & 18.5 \\
\hline 2 & 1054200 & 44.3908 & 70.9797 & Wild River & Gilead, Maine & 20.7 & 21.8 & 2.61 & 26.1 & 17.4 \\
\hline 3 & 1054300 & 44.5936 & 70.7336 & Ellis River & South Andover, Maine & 18.2 & 17.0 & 2.62 & 21.4 & 12.7 \\
\hline 4 & 1055000 & 44.6422 & 70.5881 & Swift River & Near Roxbury, Maine & 19.6 & 17.3 & 2.68 & 21.8 & 12.8 \\
\hline 7 & 1064400 & 44.0694 & 71.1750 & Lucy Brook & Near North Conway, N.H. & 24.9 & 22.2 & 2.73 & 26.8 & 17.7 \\
\hline 8 & 1064500 & 43.9908 & 71.0914 & Saco River & Near Conway, N.H. & 24.0 & 22.1 & 2.61 & 26.5 & 17.7 \\
\hline 9 & 1072850 & 43.2631 & 71.0972 & Mohawk River & Center Strafford, N.H. & 23.9 & 22.4 & 2.59 & 26.8 & 18.1 \\
\hline 10 & 1073000 & 43.1486 & 70.9656 & Oyster River & Durham, N.H. & 20.7 & 20.4 & 2.57 & 24.7 & 16.1 \\
\hline 11 & 1073600 & 42.9936 & 71.0233 & Dudley Brook & Exeter, N.H. & -- & -- & -- & -- & -- \\
\hline 12 & 1075000 & 43.9761 & 71.6800 & $\begin{array}{l}\text { Pemigewasset } \\
\text { River }\end{array}$ & Woodstock, N.H. & 26.2 & 20.6 & 2.67 & 25.1 & 16.1 \\
\hline 13 & 1075800 & 43.8367 & 71.8853 & Stevens Brook & Wentworth, N.H. & 12.3 & 16.8 & 2.65 & 21.3 & 12.4 \\
\hline 14 & 1076000 & 43.7961 & 71.8450 & Baker River & Rumney, N.H. & 17.0 & 17.7 & 2.61 & 22.0 & 13.3 \\
\hline 19 & 1085800 & 43.2592 & 72.0264 & $\begin{array}{l}\text { West Branch } \\
\text { Warner River }\end{array}$ & Near Bradford, N.H. & 22.7 & 23.5 & 2.65 & 27.9 & 19.0 \\
\hline 20 & 1086000 & 43.2517 & 71.7317 & Warner River & Davisville, N.H. & 24.0 & 20.4 & 2.57 & 24.7 & 16.1 \\
\hline 21 & 1089000 & 43.2394 & 71.4622 & Soucook River & Near Concord, N.H. & 16.4 & 17.7 & 2.60 & 22.1 & 13.4 \\
\hline 22 & 1091000 & 43.0136 & 71.6419 & $\begin{array}{l}\text { South Branch } \\
\text { Piscataquog River }\end{array}$ & Near Goffstown, N.H. & 20.0 & 18.9 & 2.59 & 23.3 & 14.6 \\
\hline 23 & 1093800 & 42.8600 & 71.8333 & $\begin{array}{l}\text { Stony Brook } \\
\text { Tributary }\end{array}$ & Near Temple, N.H. & 25.1 & 24.2 & 2.64 & 28.7 & 19.8 \\
\hline 24 & 10965852 & 42.7831 & 71.3539 & Beaver Brook & North Pelham, N.H. & 19.9 & 21.7 & 2.60 & 26.0 & 17.3 \\
\hline 25 & 1097300 & 42.5108 & 71.4069 & Nashoba Brook & Near Acton, Mass. & 20.1 & 23.2 & 2.66 & 27.7 & 18.7 \\
\hline 26 & 1101000 & 42.7528 & 70.9461 & Parker River & Byfield, Mass. & 26.1 & 24.0 & 2.70 & 28.5 & 19.5 \\
\hline 27 & 1127880 & 45.1350 & 71.2064 & Big Brook & Pittsburg, N.H. & 28.9 & 25.3 & 2.69 & 29.8 & 20.8 \\
\hline 28 & 1129440 & 44.8744 & 71.4106 & Mohawk River & Near Colebrook, N.H. & 19.2 & 21.5 & 2.58 & 25.8 & 17.2 \\
\hline
\end{tabular}


Table 9. Ground-water-recharge statistics, standard error of prediction, and 90-percent prediction interval estimated using available data and regression-equation predicted values for the annual period (January 1-December 31).-Continued

[No., number; fig., figure; in., inch; --, no data]

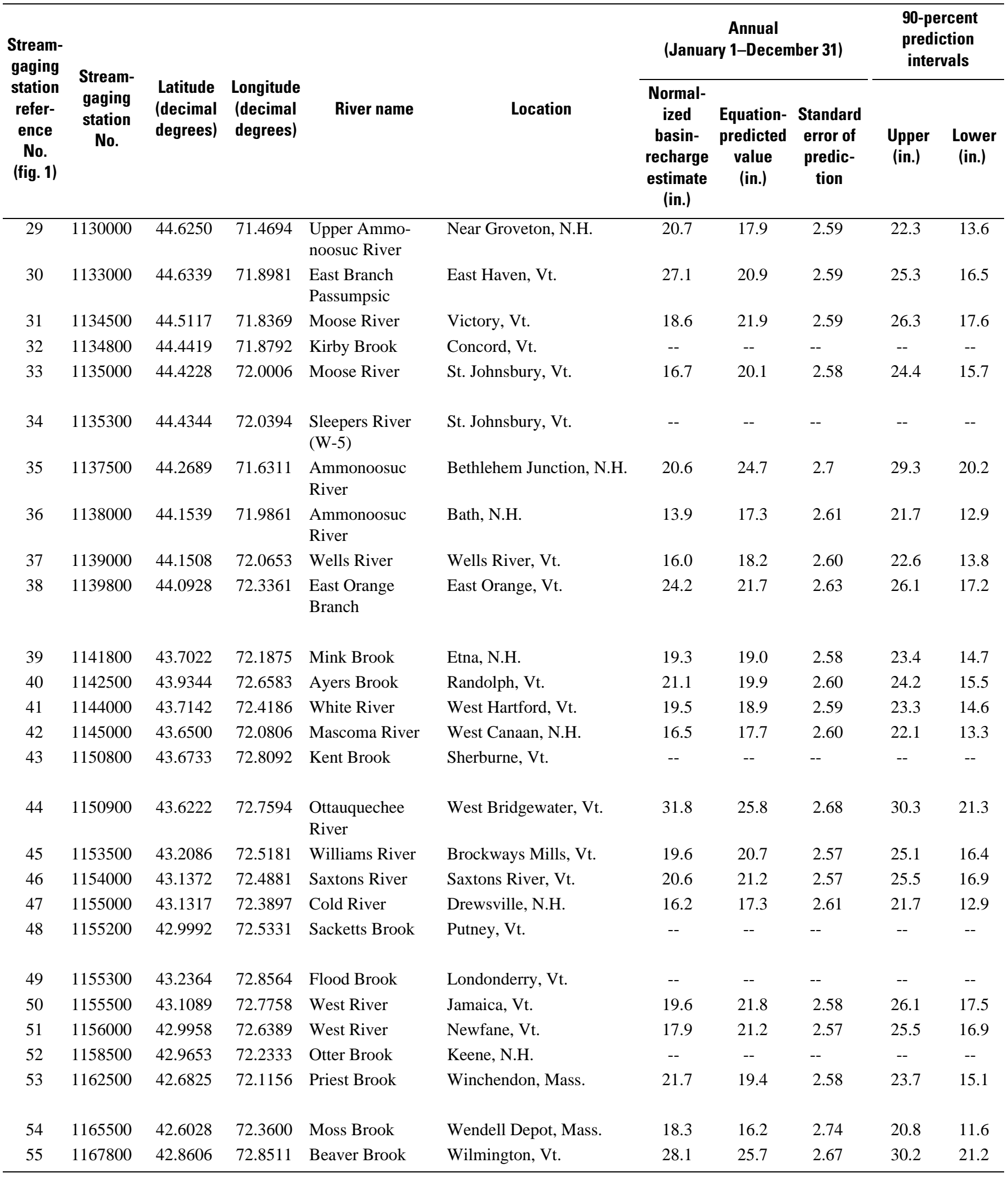


Table 10. Ground-water-recharge statistics, standard error of prediction, and 90-percent prediction interval estimated using available data and regression-equation predicted values for the winter (January 1-March 15).

[No., number; fig., figure; in., inch]

\begin{tabular}{|c|c|c|c|c|c|c|c|c|c|c|}
\hline $\begin{array}{c}\text { Stream- } \\
\text { gaging } \\
\text { station } \\
\text { refer- } \\
\text { ence } \\
\text { No. } \\
\text { (fig. 1) }\end{array}$ & $\begin{array}{c}\text { Stream- } \\
\text { gaging } \\
\text { station } \\
\text { No. }\end{array}$ & $\begin{array}{l}\text { Latitude } \\
\text { (decimal } \\
\text { degrees) }\end{array}$ & $\begin{array}{l}\text { Longitude } \\
\text { (decimal } \\
\text { degrees) }\end{array}$ & River name & Location & \multicolumn{3}{|c|}{$\begin{array}{c}\text { Winter } \\
\text { (January 1-March 15) }\end{array}$} & \multicolumn{2}{|c|}{$\begin{array}{l}\text { 90-percent } \\
\text { prediction } \\
\text { intervals }\end{array}$} \\
\hline 1 & 1052500 & 44.8778 & 71.0569 & Diamond River & Wentworth Location, N.H. & 3.07 & 2.31 & 0.68 & 3.45 & 1.16 \\
\hline 2 & 1054200 & 44.3908 & 70.9797 & Wild River & Gilead, Maine & 4.15 & 3.92 & .66 & 5.03 & 2.81 \\
\hline 3 & 1054300 & 44.5936 & 70.7336 & Ellis River & South Andover, Maine & 3.35 & 3.60 & .65 & 4.70 & 2.50 \\
\hline 4 & 1055000 & 44.6422 & 70.5881 & Swift River & Near Roxbury, Maine & 3.00 & 2.84 & .67 & 3.97 & 1.71 \\
\hline 7 & 1064400 & 44.0694 & 71.1750 & Lucy Brook & Near North Conway, N.H. & 4.54 & 4.22 & .70 & 5.40 & 3.03 \\
\hline 8 & 1064500 & 43.9908 & 71.0914 & Saco River & Near Conway, N.H. & 4.21 & 4.24 & .67 & 5.36 & 3.12 \\
\hline 9 & 1072850 & 43.2631 & 71.0972 & Mohawk River & Center Strafford, N.H. & 5.43 & 5.42 & .66 & 6.53 & 4.31 \\
\hline 10 & 1073000 & 43.1486 & 70.9656 & Oyster River & Durham, N.H. & 5.90 & 5.39 & .66 & 6.51 & 4.28 \\
\hline 11 & 1073600 & 42.9936 & 71.0233 & Dudley Brook & Exeter, N.H. & 3.95 & 5.65 & .67 & 6.77 & 4.53 \\
\hline 12 & 1075000 & 43.9761 & 71.6800 & $\begin{array}{l}\text { Pemigewasset } \\
\text { River }\end{array}$ & Woodstock, N.H. & 3.43 & 4.11 & .68 & 5.26 & 2.97 \\
\hline 13 & 1075800 & 43.8367 & 71.8853 & Stevens Brook & Wentworth, N.H. & 3.01 & 3.72 & .66 & 4.82 & 2.61 \\
\hline 14 & 1076000 & 43.7961 & 71.8450 & Baker River & Rumney, N.H. & 3.00 & 4.74 & .65 & 5.84 & 3.65 \\
\hline 19 & 1085800 & 43.2592 & 72.0264 & $\begin{array}{l}\text { West Branch } \\
\text { Warner River }\end{array}$ & Near Bradford, N.H. & 5.40 & 5.71 & .67 & 6.83 & 4.58 \\
\hline 20 & 1086000 & 43.2517 & 71.7317 & Warner River & Davisville, N.H. & 4.94 & 4.44 & .65 & 5.54 & 3.34 \\
\hline 21 & 1089000 & 43.2394 & 71.4622 & Soucook River & Near Concord, N.H. & 4.32 & 4.11 & .66 & 5.22 & 3.00 \\
\hline 22 & 1091000 & 43.0136 & 71.6419 & $\begin{array}{l}\text { South Branch } \\
\text { Piscataquog River }\end{array}$ & Near Goffstown, N.H. & 5.41 & 4.53 & .66 & 5.64 & 3.42 \\
\hline 23 & 1093800 & 42.8600 & 71.8333 & $\begin{array}{l}\text { Stony Brook } \\
\text { Tributary }\end{array}$ & Near Temple, N.H. & 6.14 & 6.06 & .67 & 7.20 & 4.93 \\
\hline 24 & 10965852 & 42.7831 & 71.3539 & Beaver Brook & North Pelham, N.H. & 6.71 & 5.73 & .67 & 6.85 & 4.62 \\
\hline 25 & 1097300 & 42.5108 & 71.4069 & Nashoba Brook & Near Acton, Mass. & 6.71 & 6.58 & .69 & 7.74 & 5.42 \\
\hline 26 & 1101000 & 42.7528 & 70.9461 & Parker River & Byfield, Mass. & 7.82 & 7.07 & .71 & 8.26 & 5.88 \\
\hline 27 & 1127880 & 45.1350 & 71.2064 & Big Brook & Pittsburg, N.H. & 4.47 & 3.78 & .75 & 5.04 & 2.53 \\
\hline 28 & 1129440 & 44.8744 & 71.4106 & Mohawk River & Near Colebrook, N.H. & 4.10 & 3.40 & .67 & 4.53 & 2.27 \\
\hline
\end{tabular}


Table 10. Ground-water-recharge statistics, standard error of prediction, and 90-percent prediction interval estimated using available data and regression-equation predicted values for the winter (January 1-March 15).-Continued

[No., number; fig., figure; in., inch]

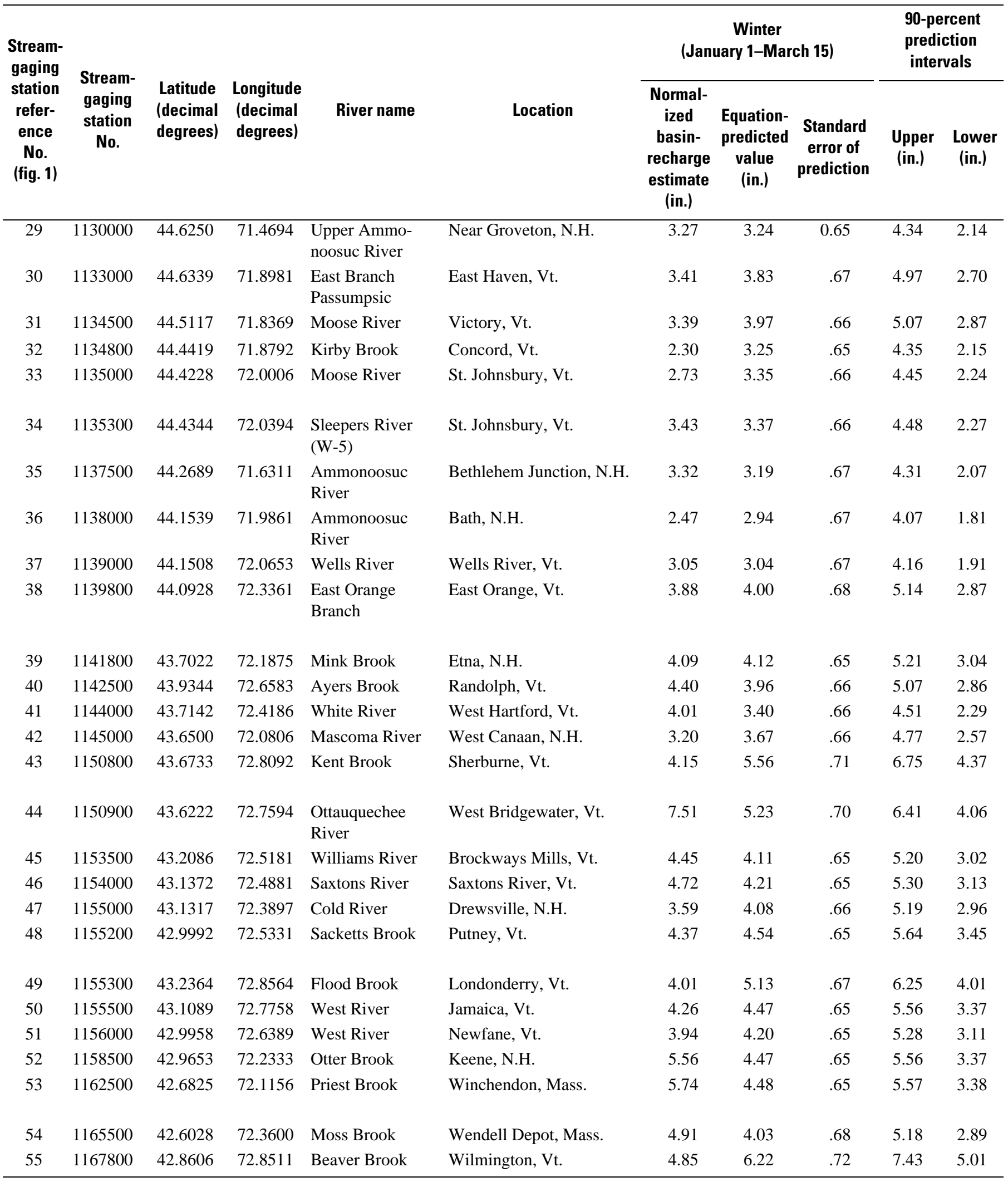


Table 11. Ground-water-recharge statistics, standard error of prediction, and 90-percent prediction interval estimated using available data and regression-equation predicted values for the spring (March 16-May 31).

[No., number; fig., figure; in., inch]

\begin{tabular}{|c|c|c|c|c|c|c|c|c|c|c|}
\hline $\begin{array}{c}\text { Stream- } \\
\text { gaging } \\
\text { station } \\
\text { refer- } \\
\text { ence } \\
\text { No. } \\
\text { (fig. 1) }\end{array}$ & $\begin{array}{c}\text { Stream- } \\
\text { gaging } \\
\text { station } \\
\text { No. }\end{array}$ & $\begin{array}{l}\text { Latitude } \\
\text { (decimal } \\
\text { degrees) }\end{array}$ & $\begin{array}{c}\text { Longitude } \\
\text { (decimal } \\
\text { degrees) }\end{array}$ & River name & Location & \multicolumn{3}{|c|}{$\begin{array}{c}\text { Spring } \\
\text { (March 16-May 31) }\end{array}$} & \multicolumn{2}{|c|}{$\begin{array}{l}\text { 90-percent } \\
\text { prediction } \\
\text { intervals }\end{array}$} \\
\hline 1 & 1052500 & 44.8778 & 71.0569 & Diamond River & Wentworth Location, N.H. & 12.1 & 10.4 & 1.15 & 12.3 & 8.43 \\
\hline 2 & 1054200 & 44.3908 & 70.9797 & Wild River & Gilead, Maine & 10.0 & 9.43 & 1.10 & 11.3 & 7.59 \\
\hline 3 & 1054300 & 44.5936 & 70.7336 & Ellis River & South Andover, Maine & 10.0 & 9.49 & 1.09 & 11.3 & 7.66 \\
\hline 4 & 1055000 & 44.6422 & 70.5881 & Swift River & Near Roxbury, Maine & 10.2 & 10.1 & 1.12 & 12.0 & 8.24 \\
\hline 7 & 1064400 & 44.0694 & 71.1750 & Lucy Brook & Near North Conway, N.H. & 10.5 & 9.60 & 1.16 & 11.5 & 7.64 \\
\hline 8 & 1064500 & 43.9908 & 71.0914 & Saco River & Near Conway, N.H. & 11.7 & 10.2 & 1.11 & 12.1 & 8.37 \\
\hline 9 & 1072850 & 43.2631 & 71.0972 & Mohawk River & Center Strafford, N.H. & 7.61 & 8.39 & 1.09 & 10.2 & 6.55 \\
\hline 10 & 1073000 & 43.1486 & 70.9656 & Oyster River & Durham, N.H. & 7.61 & 7.25 & 1.10 & 9.09 & 5.41 \\
\hline 11 & 1073600 & 42.9936 & 71.0233 & Dudley Brook & Exeter, N.H. & 5.16 & 7.33 & 1.10 & 9.18 & 5.48 \\
\hline 12 & 1075000 & 43.9761 & 71.6800 & $\begin{array}{l}\text { Pemigewasset } \\
\text { River }\end{array}$ & Woodstock, N.H. & 13.7 & 10.9 & 1.14 & 12.8 & 8.96 \\
\hline 13 & 1075800 & 43.8367 & 71.8853 & Stevens Brook & Wentworth, N.H. & 6.03 & 7.61 & 1.10 & 9.47 & 5.76 \\
\hline 14 & 1076000 & 43.7961 & 71.8450 & Baker River & Rumney, N.H. & 8.74 & 8.58 & 1.09 & 10.4 & 6.76 \\
\hline 19 & 1085800 & 43.2592 & 72.0264 & $\begin{array}{l}\text { West Branch } \\
\text { Warner River }\end{array}$ & Near Bradford, N.H. & 9.38 & 9.07 & 1.11 & 10.9 & 7.20 \\
\hline 20 & 1086000 & 43.2517 & 71.7317 & Warner River & Davisville, N.H. & 10.4 & 7.82 & 1.08 & 9.64 & 6.00 \\
\hline 21 & 1089000 & 43.2394 & 71.4622 & Soucook River & Near Concord, N.H. & 6.55 & 6.95 & 1.10 & 8.79 & 5.11 \\
\hline 22 & 1091000 & 43.0136 & 71.6419 & $\begin{array}{l}\text { South Branch } \\
\text { Piscataquog River }\end{array}$ & Near Goffstown, N.H. & 7.99 & 7.36 & 1.10 & 9.21 & 5.52 \\
\hline 23 & 1093800 & 42.8600 & 71.8333 & $\begin{array}{l}\text { Stony Brook } \\
\text { Tributary }\end{array}$ & Near Temple, N.H. & 9.34 & 8.80 & 1.11 & 10.7 & 6.94 \\
\hline 24 & 10965852 & 42.7831 & 71.3539 & Beaver Brook & North Pelham, N.H. & 6.14 & 7.59 & 1.10 & 9.44 & 5.75 \\
\hline 25 & 1097300 & 42.5108 & 71.4069 & Nashoba Brook & Near Acton, Mass. & 6.66 & 7.53 & 1.12 & 9.41 & 5.65 \\
\hline 26 & 1101000 & 42.7528 & 70.9461 & Parker River & Byfield, Mass. & 8.77 & 7.81 & 1.13 & 9.71 & 5.90 \\
\hline 27 & 1127880 & 45.1350 & 71.2064 & Big Brook & Pittsburg, N.H. & 12.4 & 12.9 & 1.24 & 15.0 & 10.9 \\
\hline 28 & 1129440 & 44.8744 & 71.4106 & Mohawk River & Near Colebrook, N.H. & 6.99 & 8.77 & 1.09 & 10.6 & 6.94 \\
\hline
\end{tabular}


Table 11. Ground-water-recharge statistics, standard error of prediction, and 90-percent prediction interval estimated using available data and regression-equation predicted values for the spring (March 16-May 31).-Continued

[No., number; fig., figure; in., inch]

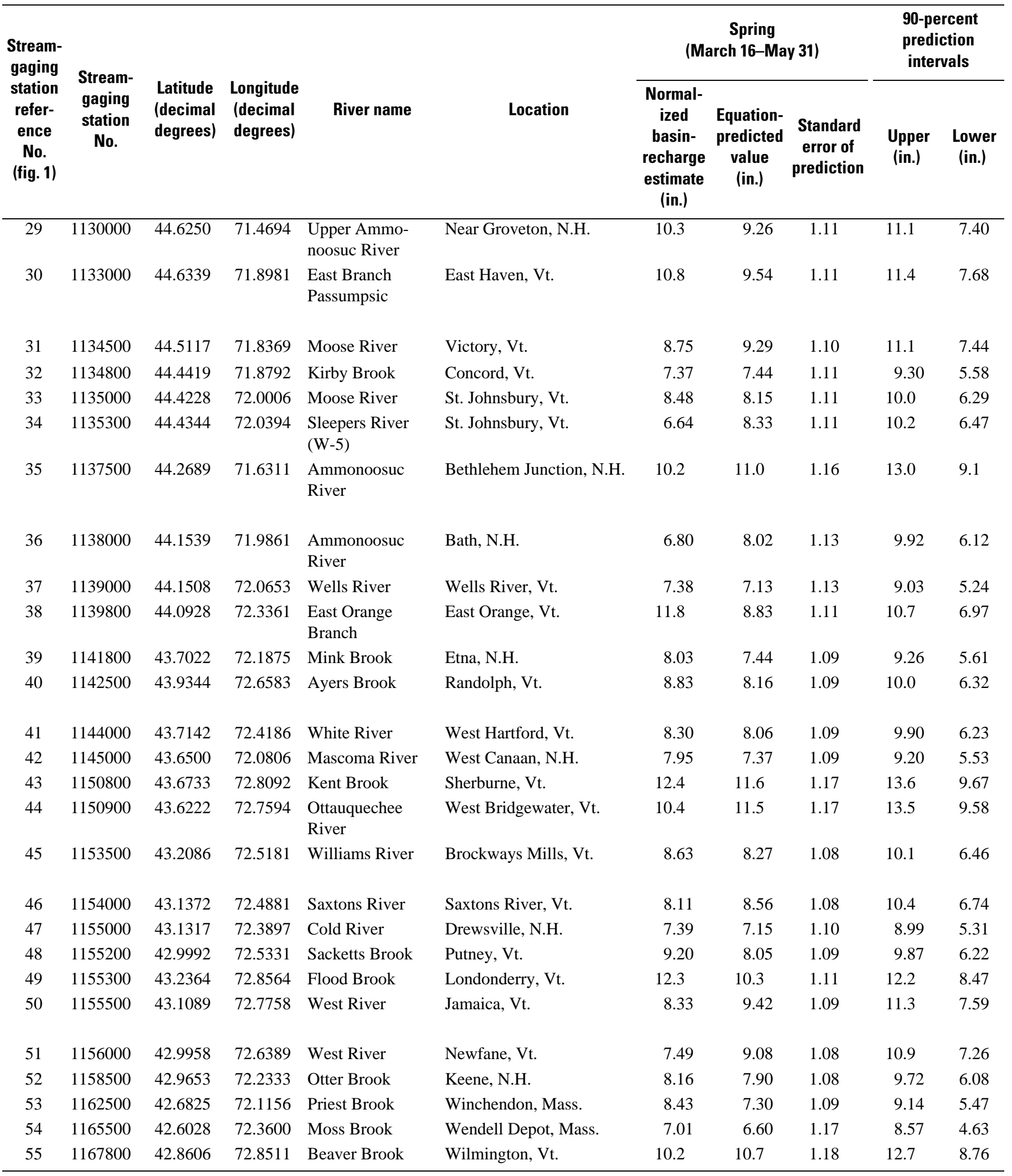


Table 12. Ground-water-recharge statistics, standard error of prediction, and 90-percent prediction interval estimated using available data and regression-equation predicted values for the summer (June 1-0ctober 31).

[No., number; fig., figure; in., inch; --, no data]

\begin{tabular}{|c|c|c|c|c|c|c|c|c|c|c|}
\hline $\begin{array}{c}\text { Stream- } \\
\text { gaging } \\
\text { station } \\
\text { refer- } \\
\text { ence } \\
\text { No. } \\
\text { (fig. 1) }\end{array}$ & $\begin{array}{l}\text { Stream- } \\
\text { gaging } \\
\text { station } \\
\text { No. }\end{array}$ & $\begin{array}{l}\text { Latitude } \\
\text { (decimal } \\
\text { degrees) }\end{array}$ & $\begin{array}{l}\text { Longitude } \\
\text { (decimal } \\
\text { degrees) }\end{array}$ & River name & Location & \multicolumn{3}{|c|}{$\begin{array}{c}\text { Summer } \\
\text { (June 1-October 31) }\end{array}$} & \multicolumn{2}{|c|}{$\begin{array}{l}\text { 90-percent } \\
\text { prediction } \\
\text { intervals }\end{array}$} \\
\hline 1 & 1052500 & 44.8778 & 71.0569 & Diamond River & Wentworth Location, N.H. & 6.69 & 4.57 & 1.10 & 6.41 & 2.72 \\
\hline 2 & 1054200 & 44.3908 & 70.9797 & Wild River & Gilead, Maine & 3.80 & 4.88 & 1.04 & 6.62 & 3.14 \\
\hline 3 & 1054300 & 44.5936 & 70.7336 & Ellis River & South Andover, Maine & 3.22 & 3.91 & 1.05 & 5.67 & 2.15 \\
\hline 4 & 1055000 & 44.6422 & 70.5881 & Swift River & Near Roxbury, Maine & 4.12 & 4.92 & 1.11 & 6.78 & 3.06 \\
\hline 7 & 1064400 & 44.0694 & 71.1750 & Lucy Brook & Near North Conway, N.H. & 3.85 & 4.65 & 1.07 & 6.44 & 2.85 \\
\hline 8 & 1064500 & 43.9908 & 71.0914 & Saco River & Near Conway, N.H. & 3.71 & 4.32 & 1.03 & 6.06 & 2.59 \\
\hline 9 & 1072850 & 43.2631 & 71.0972 & Mohawk River & Center Strafford, N.H. & 1.59 & 2.07 & 1.11 & 3.93 & .20 \\
\hline 10 & 1073000 & 43.1486 & 70.9656 & Oyster River & Durham, N.H. & 2.78 & 1.69 & 1.06 & 3.47 & .00 \\
\hline 11 & 1073600 & 42.9936 & 71.0233 & Dudley Brook & Exeter, N.H. & 1.45 & 2.47 & 1.05 & 4.23 & .71 \\
\hline 12 & 1075000 & 43.9761 & 71.6800 & $\begin{array}{l}\text { Pemigewasset } \\
\text { River }\end{array}$ & Woodstock, N.H. & 6.21 & 4.70 & 1.04 & 6.44 & 2.96 \\
\hline 13 & 1075800 & 43.8367 & 71.8853 & Stevens Brook & Wentworth, N.H. & 1.69 & 2.77 & 1.05 & 4.54 & 1.00 \\
\hline 14 & 1076000 & 43.7961 & 71.8450 & Baker River & Rumney, N.H. & 3.26 & 3.27 & 1.03 & 5.01 & 1.53 \\
\hline 19 & 1085800 & 43.2592 & 72.0264 & $\begin{array}{l}\text { West Branch } \\
\text { Warner River }\end{array}$ & Near Bradford, N.H. & 3.58 & 3.87 & 1.06 & 5.66 & 2.09 \\
\hline 20 & 1086000 & 43.2517 & 71.7317 & Warner River & Davisville, N.H. & 3.09 & 2.42 & 1.03 & 4.15 & .69 \\
\hline 21 & 1089000 & 43.2394 & 71.4622 & Soucook River & Near Concord, N.H. & 2.62 & 2.11 & 1.04 & 3.85 & .37 \\
\hline 22 & 1091000 & 43.0136 & 71.6419 & $\begin{array}{l}\text { South Branch } \\
\text { Piscataquog River }\end{array}$ & Near Goffstown, N.H. & 2.62 & 2.46 & 1.03 & 4.19 & .73 \\
\hline 23 & 1093800 & 42.8600 & 71.8333 & $\begin{array}{l}\text { Stony Brook } \\
\text { Tributary }\end{array}$ & Near Temple, N.H. & 3.71 & 3.57 & 1.04 & 5.31 & 1.82 \\
\hline 24 & 10965852 & 42.7831 & 71.3539 & Beaver Brook & North Pelham, N.H. & 2.92 & 2.78 & 1.07 & 4.57 & .99 \\
\hline 25 & 1097300 & 42.5108 & 71.4069 & Nashoba Brook & Near Acton, Mass. & 2.82 & 2.31 & 1.07 & 4.12 & .51 \\
\hline 26 & 1101000 & 42.7528 & 70.9461 & Parker River & Byfield, Mass. & 3.95 & 2.41 & 1.09 & 4.24 & .58 \\
\hline 27 & 1127880 & 45.1350 & 71.2064 & Big Brook & Pittsburg, N.H. & 10.2 & 7.60 & 1.14 & 9.52 & 5.68 \\
\hline 28 & 1129440 & 44.8744 & 71.4106 & Mohawk River & Near Colebrook, N.H. & 5.45 & 6.07 & 1.07 & 7.87 & 4.27 \\
\hline
\end{tabular}


Table 12. Ground-water-recharge statistics, standard error of prediction, and 90-percent prediction interval estimated using available data and regression-equation predicted values for the summer (June 1-0ctober 31).-Continued

[No., number; fig., figure; in., inch; --, no data]

\begin{tabular}{|c|c|c|c|c|c|c|c|c|c|c|}
\hline $\begin{array}{c}\text { Stream- } \\
\text { gaging } \\
\text { station } \\
\text { refer- } \\
\text { ence } \\
\text { No. } \\
\text { (fig. 1) }\end{array}$ & $\begin{array}{c}\text { Stream- } \\
\text { gaging } \\
\text { station } \\
\text { No. }\end{array}$ & $\begin{array}{l}\text { Latitude } \\
\text { (decimal } \\
\text { degrees) }\end{array}$ & $\begin{array}{l}\text { Longitude } \\
\text { (decimal } \\
\text { degrees) }\end{array}$ & River name & Location & \multicolumn{3}{|c|}{$\begin{array}{c}\text { Summer } \\
\text { (June 1-October 31) }\end{array}$} & \multicolumn{2}{|c|}{$\begin{array}{l}\text { 90-percent } \\
\text { prediction } \\
\text { intervals }\end{array}$} \\
\hline 29 & 1130000 & 44.6250 & 71.4694 & $\begin{array}{l}\text { Upper Ammo- } \\
\text { noosuc River }\end{array}$ & Near Groveton, N.H. & 3.18 & 4.53 & 1.03 & 6.27 & 2.80 \\
\hline 30 & 1133000 & 44.6339 & 71.8981 & $\begin{array}{l}\text { East Branch } \\
\text { Passumpsic }\end{array}$ & East Haven, Vt. & 7.40 & 5.92 & 1.06 & 7.69 & 4.15 \\
\hline 34 & 1135300 & 44.4344 & 72.0394 & $\begin{array}{l}\text { Sleepers River } \\
(\mathrm{W}-5)\end{array}$ & St. Johnsbury, Vt. & 4.19 & 4.04 & 1.04 & 5.78 & 2.30 \\
\hline 35 & 1137500 & 44.2689 & 71.6311 & $\begin{array}{l}\text { Ammonoosuc } \\
\text { River }\end{array}$ & Bethlehem Junction, N.H. & 2.66 & 5.19 & 1.04 & 6.93 & 3.44 \\
\hline 36 & 1138000 & 44.1539 & 71.9861 & $\begin{array}{l}\text { Ammonoosuc } \\
\text { River }\end{array}$ & Bath, N.H. & 2.38 & 3.00 & 1.05 & 4.75 & 1.24 \\
\hline 37 & 1139000 & 44.1508 & 72.0653 & Wells River & Wells River, Vt. & 3.81 & 3.40 & 1.04 & 5.15 & 1.66 \\
\hline 38 & 1139800 & 44.0928 & 72.3361 & $\begin{array}{l}\text { East Orange } \\
\text { Branch }\end{array}$ & East Orange, Vt. & 4.59 & 4.96 & 1.03 & 6.69 & 3.23 \\
\hline 45 & 1153500 & 43.2086 & 72.5181 & Williams River & Brockways Mills, Vt. & 3.26 & 3.36 & 1.03 & 5.09 & 1.62 \\
\hline 46 & 1154000 & 43.1372 & 72.4881 & Saxtons River & Saxtons River, Vt. & 3.33 & 3.58 & 1.02 & 5.30 & 1.86 \\
\hline 47 & 1155000 & 43.1317 & 72.3897 & Cold River & Drewsville, N.H. & 2.54 & 2.40 & 1.03 & 4.13 & 0.66 \\
\hline 48 & 1155200 & 42.9992 & 72.5331 & Sacketts Brook & Putney, Vt. & 3.55 & 3.30 & 1.04 & 5.06 & 1.55 \\
\hline 49 & 1155300 & 43.2364 & 72.8564 & Flood Brook & Londonderry, Vt. & 3.24 & 5.42 & 1.07 & 7.22 & 3.63 \\
\hline 50 & 1155500 & 43.1089 & 72.7758 & West River & Jamaica, Vt. & 3.70 & 4.74 & 1.04 & 6.49 & 2.99 \\
\hline 51 & 1156000 & 42.9958 & 72.6389 & West River & Newfane, Vt. & 3.67 & 4.00 & 1.04 & 5.75 & 2.24 \\
\hline 52 & 1158500 & 42.9653 & 72.2333 & Otter Brook & Keene, N.H. & -- & -- & -- & -- & -- \\
\hline 53 & 1162500 & 42.6825 & 72.1156 & Priest Brook & Winchendon, Mass. & 3.89 & 2.87 & 1.03 & 4.60 & 1.15 \\
\hline 54 & 1165500 & 42.6028 & 72.3600 & Moss Brook & Wendell Depot, Mass. & 2.90 & 3.10 & 1.03 & 4.83 & 1.37 \\
\hline 55 & 1167800 & 42.8606 & 72.8511 & Beaver Brook & Wilmington, Vt. & 4.66 & 5.96 & 1.11 & 7.83 & 4.09 \\
\hline
\end{tabular}


Table 13. Ground-water-recharge statistics, standard error of prediction, and 90-percent prediction interval estimated using available data and regression-equation predicted values for the fall (November 1-December 31).

[No., number, fig., figure; in., inch; --, no data]

\begin{tabular}{|c|c|c|c|c|c|c|c|c|c|c|}
\hline $\begin{array}{c}\text { Stream- } \\
\text { gaging } \\
\text { station } \\
\text { refer- } \\
\text { ence } \\
\text { No. } \\
\text { (fig. 1) }\end{array}$ & $\begin{array}{c}\text { Stream- } \\
\text { gaging } \\
\text { station } \\
\text { No. }\end{array}$ & $\begin{array}{l}\text { Latitude } \\
\text { (decimal } \\
\text { degrees) }\end{array}$ & $\begin{array}{c}\text { Longitude } \\
\text { (decimal } \\
\text { degrees) }\end{array}$ & River name & Location & \multicolumn{3}{|c|}{$\begin{array}{c}\text { Fall } \\
\text { (November 1-December 31) }\end{array}$} & \multicolumn{2}{|c|}{$\begin{array}{l}\text { 90-percent } \\
\text { prediction } \\
\text { intervals }\end{array}$} \\
\hline 1 & 1052500 & 44.8778 & 71.0569 & Diamond River & Wentworth Location, N.H. & 3.84 & 3.64 & 0.56 & 4.58 & 2.70 \\
\hline 2 & 1054200 & 44.3908 & 70.9797 & Wild River & Gilead, Maine & 2.93 & 3.60 & .57 & 4.55 & 2.64 \\
\hline 3 & 1054300 & 44.5936 & 70.7336 & Ellis River & South Andover, Maine & 3.08 & 3.15 & .56 & 4.09 & 2.21 \\
\hline 4 & 1055000 & 44.6422 & 70.5881 & Swift River & Near Roxbury, Maine & 3.40 & 2.72 & .58 & 3.69 & 1.75 \\
\hline 7 & 1064400 & 44.0694 & 71.1750 & Lucy Brook & Near North Conway, N.H. & 3.99 & 3.53 & .59 & 4.53 & 2.53 \\
\hline 8 & 1064500 & 43.9908 & 71.0914 & Saco River & Near Conway, N.H. & 3.95 & 3.77 & .57 & 4.72 & 2.81 \\
\hline 9 & 1072850 & 43.2631 & 71.0972 & Mohawk River & Center Strafford, N.H. & 4.23 & 4.31 & .57 & 5.27 & 3.35 \\
\hline 10 & 1073000 & 43.1486 & 70.9656 & Oyster River & Durham, N.H. & 4.02 & 3.97 & .56 & 4.92 & 3.03 \\
\hline 11 & 1073600 & 42.9936 & 71.0233 & Dudley Brook & Exeter, N.H. & 2.39 & 3.85 & .56 & 4.79 & 2.91 \\
\hline 12 & 1075000 & 43.9761 & 71.6800 & $\begin{array}{l}\text { Pemigewasset } \\
\text { River }\end{array}$ & Woodstock, N.H. & 4.00 & 2.97 & .58 & 3.95 & 1.99 \\
\hline 13 & 1075800 & 43.8367 & 71.8853 & Stevens Brook & Wentworth, N.H. & 2.36 & 2.71 & .57 & 3.67 & 1.75 \\
\hline 14 & 1076000 & 43.7961 & 71.8450 & Baker River & Rumney, N.H. & 2.81 & 3.00 & .57 & 3.95 & 2.05 \\
\hline 19 & 1085800 & 43.2592 & 72.0264 & $\begin{array}{l}\text { West Branch } \\
\text { Warner River }\end{array}$ & Near Bradford, N.H. & 4.04 & 4.19 & .57 & 5.15 & 3.22 \\
\hline 20 & 1086000 & 43.2517 & 71.7317 & Warner River & Davisville, N.H. & 4.26 & 3.60 & .56 & 4.54 & 2.66 \\
\hline 21 & 1089000 & 43.2394 & 71.4622 & Soucook River & Near Concord, N.H. & 2.96 & 3.10 & .56 & 4.05 & 2.16 \\
\hline 22 & 1091000 & 43.0136 & 71.6419 & $\begin{array}{l}\text { South Branch } \\
\text { Piscataquog River }\end{array}$ & Near Goffstown, N.H. & 3.66 & 3.28 & .56 & 4.22 & 2.34 \\
\hline 23 & 1093800 & 42.8600 & 71.8333 & $\begin{array}{l}\text { Stony Brook } \\
\text { Tributary }\end{array}$ & Near Temple, N.H. & 4.90 & 4.37 & .57 & 5.33 & 3.40 \\
\hline 24 & 10965852 & 42.7831 & 71.3539 & Beaver Brook & North Pelham, N.H. & 4.59 & 4.07 & .57 & 5.03 & 3.12 \\
\hline 25 & 1097300 & 42.5108 & 71.4069 & Nashoba Brook & Near Acton, Mass. & 3.82 & 4.44 & .58 & 5.42 & 3.46 \\
\hline 26 & 1101000 & 42.7528 & 70.9461 & Parker River & Byfield, Mass. & 4.84 & 4.78 & .60 & 5.78 & 3.78 \\
\hline 27 & 1127880 & 45.1350 & 71.2064 & Big Brook & Pittsburg, N.H. & 4.82 & 4.22 & .57 & 5.18 & 3.26 \\
\hline 28 & 1129440 & 44.8744 & 71.4106 & Mohawk River & Near Colebrook, N.H. & 4.07 & 3.45 & .56 & 4.39 & 2.51 \\
\hline
\end{tabular}


Table 13. Ground-water-recharge statistics, standard error of prediction, and 90-percent prediction interval estimated using available data and regression-equation predicted values for the fall (November 1-December 31).-Continued

[No., number, fig., figure; in., inch; --, no data]

\begin{tabular}{|c|c|c|c|c|c|c|c|c|c|c|}
\hline \multirow{2}{*}{$\begin{array}{c}\text { Stream- } \\
\text { gaging } \\
\text { station } \\
\text { refer- } \\
\text { ence } \\
\text { No. } \\
\text { (fig. 1) }\end{array}$} & \multirow[b]{2}{*}{$\begin{array}{c}\text { Stream- } \\
\text { gaging } \\
\text { station } \\
\text { No. }\end{array}$} & \multirow[b]{2}{*}{$\begin{array}{l}\text { Latitude } \\
\text { (decimal } \\
\text { degrees) }\end{array}$} & \multirow[b]{2}{*}{$\begin{array}{r}\text { Longitude } \\
\text { (decimal } \\
\text { degrees) }\end{array}$} & \multirow[b]{2}{*}{ River name } & \multirow[b]{2}{*}{ Location } & \multicolumn{3}{|c|}{$\begin{array}{c}\text { Fall } \\
\text { (November 1-December 31) }\end{array}$} & \multicolumn{2}{|c|}{$\begin{array}{l}\text { 90-percent } \\
\text { prediction } \\
\text { intervals }\end{array}$} \\
\hline & & & & & & $\begin{array}{l}\text { Normal- } \\
\text { ized } \\
\text { basin- } \\
\text { recharge } \\
\text { estimate } \\
\text { (in.) }\end{array}$ & $\begin{array}{l}\text { Equation- } \\
\text { predicted } \\
\text { value } \\
\text { (in.) }\end{array}$ & $\begin{array}{l}\text { Standard } \\
\text { error of } \\
\text { prediction }\end{array}$ & $\begin{array}{l}\text { Upper } \\
\text { (in.) }\end{array}$ & $\begin{array}{l}\text { Lower } \\
\text { (in.) }\end{array}$ \\
\hline 29 & 1130000 & 44.6250 & 71.4694 & $\begin{array}{l}\text { Upper Ammo- } \\
\text { noosuc River }\end{array}$ & Near Groveton, N.H. & 2.55 & 2.93 & 0.56 & 3.87 & 1.98 \\
\hline 30 & 1133000 & 44.6339 & 71.8981 & $\begin{array}{l}\text { East Branch } \\
\text { Passumpsic }\end{array}$ & East Haven, Vt. & 4.26 & 3.52 & .56 & 4.46 & 2.57 \\
\hline 31 & 1134500 & 44.5117 & 71.8369 & Moose River & Victory, Vt. & 3.31 & 3.68 & .56 & 4.63 & 2.74 \\
\hline 32 & 1134800 & 44.4419 & 71.8792 & Kirby Brook & Concord, Vt. & 2.26 & 3.07 & .56 & 4.01 & 2.12 \\
\hline 33 & 1135000 & 44.4228 & 72.0006 & Moose River & St. Johnsbury, Vt. & 2.58 & 3.33 & .56 & 4.27 & 2.39 \\
\hline 34 & 1135300 & 44.4344 & 72.0394 & $\begin{array}{l}\text { Sleepers River } \\
(\mathrm{W}-5)\end{array}$ & St. Johnsbury, Vt. & 3.95 & 3.33 & .56 & 4.27 & 2.39 \\
\hline 35 & 1137500 & 44.2689 & 71.6311 & $\begin{array}{l}\text { Ammonoosuc } \\
\text { River }\end{array}$ & Bethlehem Junction, N.H. & 3.02 & 3.98 & .58 & 4.96 & 3.00 \\
\hline 36 & 1138000 & 44.1539 & 71.9861 & $\begin{array}{l}\text { Ammonoosuc } \\
\text { River }\end{array}$ & Bath, N.H. & 2.21 & 2.74 & .57 & 3.69 & 1.78 \\
\hline 37 & 1139000 & 44.1508 & 72.0653 & Wells River & Wells River, Vt. & 2.85 & 3.16 & .56 & 4.11 & 2.21 \\
\hline 38 & 1139800 & 44.0928 & 72.3361 & $\begin{array}{l}\text { East Orange } \\
\text { Branch }\end{array}$ & East Orange, Vt. & 3.58 & 3.76 & .57 & 4.72 & 2.80 \\
\hline 39 & 1141800 & 43.7022 & 72.1875 & Mink Brook & Etna, N.H. & 2.99 & 3.00 & .56 & 3.95 & 2.05 \\
\hline 40 & 1142500 & 43.9344 & 72.6583 & Ayers Brook & Randolph, Vt. & 3.33 & 3.54 & .56 & 4.49 & 2.59 \\
\hline 41 & 1144000 & 43.7142 & 72.4186 & White River & West Hartford, Vt. & 3.37 & 3.35 & .56 & 4.29 & 2.40 \\
\hline 42 & 1145000 & 43.6500 & 72.0806 & Mascoma River & West Canaan, N.H. & 2.63 & 2.80 & .57 & 3.75 & 1.85 \\
\hline 43 & 1150800 & 43.6733 & 72.8092 & Kent Brook & Sherburne, Vt. & 6.06 & 4.52 & .58 & 5.49 & 3.55 \\
\hline 44 & 1150900 & 43.6222 & 72.7594 & $\begin{array}{l}\text { Ottauquechee } \\
\text { River }\end{array}$ & West Bridgewater, Vt. & 5.22 & 4.21 & .57 & 5.16 & 3.25 \\
\hline 45 & 1153500 & 43.2086 & 72.5181 & Williams River & Brockways Mills, Vt. & 2.82 & 3.42 & .56 & 4.36 & 2.48 \\
\hline 46 & 1154000 & 43.1372 & 72.4881 & Saxtons River & Saxtons River, Vt. & 3.23 & 3.43 & .56 & 4.36 & 2.49 \\
\hline 47 & 1155000 & 43.1317 & 72.3897 & Cold River & Drewsville, N.H. & 2.44 & 2.64 & .57 & 3.60 & 1.68 \\
\hline 48 & 1155200 & 42.9992 & 72.5331 & Sacketts Brook & Putney, Vt. & 2.81 & 3.69 & .56 & 4.64 & 2.75 \\
\hline 49 & 1155300 & 43.2364 & 72.8564 & Flood Brook & Londonderry, Vt. & 4.08 & 3.98 & .56 & 4.92 & 3.03 \\
\hline 50 & 1155500 & 43.1089 & 72.7758 & West River & Jamaica, Vt. & 3.44 & 3.45 & .56 & 4.39 & 2.51 \\
\hline 51 & 1156000 & 42.9958 & 72.6389 & West River & Newfane, Vt. & 2.99 & 3.35 & .56 & 4.29 & 2.41 \\
\hline 52 & 1158500 & 42.9653 & 72.2333 & Otter Brook & Keene, N.H. & -- & -- & -- & -- & -- \\
\hline 53 & 1162500 & 42.6825 & 72.1156 & Priest Brook & Winchendon, Mass. & 3.73 & 3.16 & .56 & 4.10 & 2.22 \\
\hline 54 & 1165500 & 42.6028 & 72.3600 & Moss Brook & Wendell Depot, Mass. & 2.96 & 2.20 & .60 & 3.21 & 1.20 \\
\hline 55 & 1167800 & 42.8606 & 72.8511 & Beaver Brook & Wilmington, Vt. & 4.95 & 4.29 & .57 & 5.25 & 3.33 \\
\hline
\end{tabular}





\section{Appendix 1. Basin and Climate Characteristics Tested for Significance in the Ground-water Recharge Regression Analysis}

- Total drainage area, in square miles, is the area measured in a horizontal plane that is enclosed by a drainage divide.

- Basin length, in miles, is the length of the basin measured along a line areally centered through the drainage divide data layer from the basin outlet to where the main channel extended meets the basin divide.

- Basin perimeter, in miles, is the length as measured along the entire drainage-basin boundary.

- Average basin slope, in percent, is the average slope of the drainage basin measured using a Digital Elevation Model (DEM) in the computer software ARC-INFO.

- Basin relief, in feet, is the measured difference between the elevation of the highest grid cell and the elevation of the grid cell at the basin outlet. A lattice data layer, created using ARC-INFO, is used to determine the minimum and maximum land-surface elevation.

- Basin azimuth, in degrees, is the direction of a line projected from where the main channel meets the basin divide downslope to the basin outlet (clockwise from north $=0$ degrees).

- Basin azimuth, in radians.

- Basin azimuth region, Four quadrants where 0-90 degrees $=1,90-180$ degrees $=2,180-270$ degrees $=3$, and 270-360 degrees $=4$.

- Effective basin width, in miles, is the ratio of the total drainage area to the basin length.

- Shape factor, dimensionless, is the ratio of basin length to the effective basin width.

- Compactness ratio, dimensionless, is the ratio of the perimeter of the basin to the circumference of a circle of equal area.

- Relative relief, in foot/mile, is the ratio of the basin relief to the basin perimeter.

- Main channel length, in miles, is measured along the main channel from the basin outlet to where the main channel meets the basin divide using centerlined hydrography.

- Main channel slope, in foot/mile, is the slope of the main channel based on the difference in streambed elevation at points 10 and 85 percent of the distance along the main channel from the basin outlet to the basin divide.

- Main channel sinuosity ratio, dimensionless, is the ratio of the main channel length to the basin length.
- Stream density, in miles per square mile, is the ratio of the main channel length to the drainage area.

- Main channel slope proportion, dimensionless, is the ratio of the main channel length to the square root of the main channel slope.

- Ruggedness number, in foot/mile, is the product of the stream density multiplied by the Basin Relief.

- Slope ratio, dimensionless, is the ratio of the main channel slope to the basin slope.

- Minimum basin elevation, in feet, is the minimum elevation in the drainage basin based on the intersection of the basin polygon coverages and the DEMs.

- Maximum basin elevation, in feet, is the maximum elevation in the drainage basin based on the intersection of the basin polygon coverages and the DEMs.

- Mean basin elevation, in feet, is mean basin elevation in the drainage basin based on the intersection of the basin polygon coverages and the DEMs.

- Median basin elevation, in feet, is the median basin elevation in the drainage basin based on the intersection of the basin polygon coverages and the DEMs.

- Ground-water head, in feet, is a surrogate for the effective head in the sand and gravel deposits determined by subtracting the minimum basin elevation from the mean basin elevation.

- Basin elevation group, either a "1" or a " 2 ", is based on the median value of the mean basin elevations for all 60 basins used to develop the regression equations, which is 1,498 feet above mean sea level. A " 1 " indicates that the mean basin elevation is above this value and a "2" indicates that the mean basin elevation is below this value.

- Standardized centroid latitude and longitude is the latitude and longitude of the basin centroid, which was standardized by replacing the centroid latitude (and similarly centroid longitude) of each basin with [Latitude-mean (Latitude)] divided by the Standard Deviation (Latitude). The standardized latitude and longitude are symmetrically distributed with a mean of zero and a standard deviation of one.

- Centroid latitude and longitude, in decimal degrees, is the latitude and longitude at the centroid of the drainage basin.

- Significant sand and gravel deposits, in square miles plus 0.01 , is the total area of sand and gravel deposits in the basin plus 0.01 . 
- Percent sand and gravel in basin, in percent plus 0.01 , is the percentage of the total drainage basin area, which has sand and gravel deposits, to the total drainage basin area plus 0.01 .

- Ratio of sand and gravel in basin in contact with stream network to total drainage basin area, in percent plus 0.01 , is the percent of drainage basin underlain by sand and gravel, which is in contact with the stream network (based on the intersection of stream centerline data and polygon coverages of sand and gravel deposits) as a percentage of the total drainagebasin area.

- Minimum elevation of sand and gravel deposits, in feet, is the minimum elevation of the sand and gravel deposits based upon DEMs and sand and gravel data.

- Maximum elevation of sand and gravel deposits, in feet, is the maximum elevation of the sand and gravel deposits based upon DEMs and sand and gravel data.

- Mean elevation of sand and gravel deposits, in feet, is the mean elevation of the sand and gravel deposits based upon DEMs and sand and gravel data.

- Maximum sand and gravel deposit elevation above minimum basin elevation, in feet plus 0.01 , is the difference in elevation between the maximum and minimum sand and gravel deposit elevations as determined from DEMs and sand and gravel data (plus 0.01).

- Mean sand and gravel deposit elevation above minimum basin elevation, in feet plus 0.01 , is the difference in elevation between the mean sand and gravel deposit elevation and the minimum basin elevation based upon DEMs and sand and gravel data (plus 0.01).

- Mean sand and gravel deposit elevation above minimum basin elevation divided by drainage area, in feet plus 0.01 , is the difference in elevation between the mean sand and gravel deposit elevation and the minimum basin elevation divided by drainage area and based upon DEMs and sand and gravel data (plus 0.01).

- Relief of sand and gravel deposits, in feet plus 0.01, is the difference between the maximum sand and gravel elevation and minimum sand and gravel elevation based upon DEMs and sand and gravel data (plus 0.01).

- Mean annual and seasonal precipitation, in inches, at a stream-gaging station, is from PRISM average monthly and annual precipitation data for 1961-90. It is based on 2-kilometer grid data. Five parameters were determined based on these data:

- annual gage

- winter gage (January 1-March 15)

- $\quad$ spring gage (March 16-May 31)

- $\quad$ summer gage (June 1-October 31)

- fall gage (November 1-December 31)
- Mean annual and seasonal precipitation, in inches, at the centroid of the basin, is from PRISM average monthly and annual precipitation data for 1961-90. It is based on 2-kilometer grid data. Five parameters were determined based on these data:

- annual centroid

- winter centroid (January 1-March 15)

- spring centroid (March 16-May 31)

- summer centroid (June 1-October 31)

- fall centroid (November 1-December 31)

- Mean annual and seasonal precipitation, in inches, as a basin average for the drainage basin, is from PRISM average monthly and annual precipitation data for 1961-90. It is based on 2-kilometer grid data. Five parameters were determined based on these data:

- annual basin

- winter basin (January 1-March 15)

- spring basin (March 16-May 31)

- summer basin (June 1-October 31)

- fall basin (November 1-December 31)

- Average mean, minimum and maximum annual and seasonal basin temperature, in degrees Fahrenheit, is based on monthly data acquired from PRISM for 1961-90. It is based on 2-kilometer grid data. The temperature values for the entire month of March were used for each of the seasonal "half March" periods:

- annual basin mean, minimum, maximum

- winter basin mean, minimum, maximum (January 1-March 31)

- spring basin mean, minimum, maximum (March 1-May 31)

- summer basin mean, minimum, maximum (June 1-October 31)

- fall basin mean, minimum, maximum (November 1-December 31)

- Soil drainage, in percent, is the percentage of drainage basin that is well drained as determined from STATSGO (State Soil Geographic) (Schwarz and Alexander, 1995, and U.S. Department of Agriculture, 1991) data.

- Mean permeability, in inches per hour, is the mean permeability in each basin as determined from STATSGO (Schwarz and Alexander, 1995, and U.S. Department of Agriculture, 1991) data.

- 32fday, in days, is the seasonally and annually determined basinwide average number of days in which the temperature was a minimum of 32 degrees or less. The seasonal value for the month of March was determined 
by dividing the March value in half (assumes uniform distribution).

- annual basinwide

- winter basinwide (January 1-March 15)

- spring basinwide (March 16-May 31)

- summer basinwide (June 1-October 31)

- fall basinwide (November 1-December 31)

- Curve_25thquartile, dimensionless, is the curvature of the basin based on a DEM for all of New Hampshire and Vermont and part of Maine and Massachusetts. The area encompasses all of the 60 basins used in this study. The curvature command was used in a grid of the DEM. A slope and a curvature grid were generated. The lowest 25 percent of slope and curvature grid cells were given a value of one while everything else was given a value of zero. These two grids were then cross-multiplied and a grid was produced that identifies those cells representing the lowest 25 percent of both slope and curvature. The curvature grid calculates the curvature of a surface at each cell center and the slope grid show the rate of maximum change in $\mathrm{Z}$ value from each cell. Slope is the first derivative of surface; curvature is the second derivative of surface. A negative value indicates that the surface (relative to a best fit plane) is concave at that cell. The basin characteristic is the lowest 25percent quartile of curvature and slope relative to a best fit plane and indicates the smallest change in $\mathrm{Z}$ value from each cell (slope grid) and most curved cell surface (curvature grid). This grid was intersected with the basin grids to obtain percent flat and curved in each basin.

- Curve cell_relief, dimensionless, is the relief (maximum-minimum) of curvature of the basin grid surface at each cell center for each basin.

- Profile curve (mean, minimum, maximum), dimensionless, is the average curvature of the grid surface at each cell center in the direction of slope for each basin.

- Total stream length, in miles, is the total length of all streams in the basin.

- Area of water bodies, in square miles plus 0.01 , is the total area of water bodies in the basin.

- Percent water bodies, in percent plus 0.01, is the percent of each drainage basin that contains a body of water.

- Area of sand and gravel in contact with the stream network, in square feet plus 0.01 , is the total area of sand and gravel in each drainage basin in contact with the stream network.
- Ratio of sand and gravel deposits to streams which are in contact with the sand and gravel deposits in the basin, in miles plus 0.01 , is the ratio of the square miles of sand and gravel deposits to the miles of stream length in contact with the sand and gravel deposits plus 0.01 .

- Ratio of sand and gravel deposits to the total stream length in the basin, in miles plus 0.01 , is the ratio of the square miles of sand and gravel deposits to the miles of total stream length plus 0.01 . The stream centerline data was intersected with the polygon coverages of sand and gravel deposits.

- Annual snowcover, in inches, is the mean annual basin average snowfall for each of the basins based on monthly data acquired from 2-kilometer PRISM grid data for 1961-90.

- Forest coverage, in percent, is National Land Cover Data Set (NLCD) data used to determine the percent of the basin that is forested.

- Deciduous forest, in percent, is the percent of the basin that is deciduous. Defined in NLCD metadata as areas dominated by trees where 75 percent or more of the tree species shed foliage simultaneously in response to seasonal change.

- Coniferous forest, in percent, is the percent of the basin that is coniferous. Defined in NLCD metadata as areas dominated by trees where 75 percent or more of the tree species maintain their leaves all year. Canopy is never without green foliage.

- Mixed coniferous/deciduous forest, in percent, is the percent of the basin that is mixed coniferous and deciduous. Defined in NLCD metadata as areas dominated by trees where neither deciduous nor evergreen species represent more than 75 percent of the cover present.

- Hypsometric curve area, dimensionless, is the area under the curve for a hypsometric curve of the basin elevation. Elevation data was grouped in equal-area classifications to create a hypsometric curve and the area under the curve was determined by summing the products of elevation and basin area above a given maximum elevation for each of the particular equal area groupings.

\section{Reference Cited}

U.S. Department of Agriculture, Natural Resources Conservation Service, National Soil Survey Center, 1991, State Soil Geographic (STATSGO) Data Base: Data use information: Miscellaneous Publication No. 1492, 110 p. (revised July 1994). 